\title{
On the Function of the Thyroid Gland in Rabbits Descended from Ancestors with Dysfunction in their Thyroid Gland for Several Successive Generations.
}

By

\author{
Takaaki YAMASAKI \\ Postgraduate, the Pathological Institute, Kyoto University, School of Medicine \\ (Director : Prof. Kozo Okamoto)
}

I. On the Thyroid Function of Normal Control Rabbits

Using normal mature rabbits (10 males and 10 females) 2,000 3,000g. in body weight, their serum PBI was measured by a modified distillation method based on BARKER's and CONNOR's methods and their total blood cholesterol by modified BLOOR's method; 6 male and 6 female rabbits were used for measuring the $\mathrm{I}^{131}$ uptake rate of their thyroid gland following FIELDS's method in principle. The results were in summary as follows :

1. The mean serum PBI content was $4.6 \pm 0.71 \gamma / \mathrm{dl}(3.7 \sim 6.4 \gamma / \mathrm{dl})$. No difference was perceptible between the values for males and females.

2. The mean total blood cholesterol content registered $82 \pm 14.9 \mathrm{mg} / \mathrm{dl}(59 \sim 110 \mathrm{mg} / \mathrm{dl})$.

3. The mean $\mathrm{I}^{131}$ uptake rate on the thyroid gland was $21.8 \pm 10.4 \%$ in one hour value after $\mathrm{NaI}^{131}$ injection; $29.5 \pm 8.8 \%$ in 3 hours value; $30.5 \pm 8.8 \%$ in 6 hours value; $22.0 \pm 6.7 \%$ in 12 hour value; $15.7 \pm 5.6 \%$ in 24 hour value; $11.4 \pm 6.8 \%$ in 48 hour value; $8.5 \pm 5.5 \%$ in 72 hour value.

The mean values for the 6 males were lower than those for the 6 females in the first 24 hours, but in the later hours, the values were higher for the males than for the females.

II. The Function of the Thyroid Gland in $\mathrm{F}_{1}, \mathrm{~F}_{4}, \mathrm{~F}_{5}$ and $\mathrm{F}_{6}$ Rabbits Descended from Ancestor with Dysfunction in the Thyroid Gland in Every Case for Several Successive Generations

1. For successive generation, a breed of rabbits were made to suffer from hyperfunction of the thyroid gland before mating by oral administration of $30 \mathrm{mg} / \mathrm{kg}$ of powdered thyroid gland for not less than one month, and the youngs begotten from them $\left(\mathrm{F}_{1}, \mathrm{~F}_{4}, \mathrm{~F}_{5}, \mathrm{~F}_{6}\right)$ were used for similar measurements as in I above in 50-210 days after birth. It was confirmed that the serum PBI content and the $\mathrm{I}^{131}$ uptake rate of the thyroid rose higher in them than in the normal control, and ever rising higher from generation to generation, so that at last in $F_{6}$, the mean serum PBI value was heightened to $220 \%(10.0 \pm 1.07 \mathrm{r} / \mathrm{dl})$ of that of the controls, while the $\mathrm{I}^{131}$ uptake rate rose to 3 folds of the normal in 1 hour value, to $220 \%$ in 3 hour and to $190 \%$ in 6 hour values. These findings suggest that these offspring rabbits suffer from hyperfunction of the thyroid gland aggravating from generation to generation, so that a complete state of hyperthyroidism is finally brought about in most of the $F_{5}$ rabbits and later generations.

2. In 5 rabbits given powdered thyroid gland, the mean serum PBI value was higher than normal $(9.6 \pm 1.11 \mathrm{r} / \mathrm{dl})$, the mean total blood cholesterol value a little below normal $(78 \pm 13.5 \mathrm{mg} / \mathrm{dl})$ and the mean $\mathrm{I}^{131}$ uptake rate of the thyroid gland obviously lower and more retarded than in normal cases.

3. In the offsprings $\left(F_{1}\right.$ and $\left.F_{4}\right) 50 \sim 220$ days after birth from parents, both male and female, with their thyroid gland ectomized at least one month before mating, in every case for successive generations, the serum PBI value was always subnormal, the value falling off further by every generation, 
the total blood cholesterol content was above normal and rose higher by every generation, and also the $I^{131}$ uptake rate was always supernormal and higher in $F_{4}$ than in $F_{1}$. From these findings it may be deduced that these offspring rabbits suffer from hypothyroidism mainly consisting in disturbed hormone elaboration in the gland and aggravating from generation to generation.

4. In 5 thyroidectomized rabbits, the mean serum PBI value was below normal $(3.0 \pm 0.44 \gamma / \mathrm{dl})$, the mean total blood cholesterol content was above normal $(118 \pm 35.9 \mathrm{mg} / \mathrm{dl})$ and the mean $\mathrm{I}^{131}$ uptake rate in 4 such rabbits was found markedly fallen below normal.

\section{The Effect of Testosterone and Various Types of Treatment on the Urinary Excretion of Steroid Hormones in Diabetes Mellitus.}

By

\section{Nobuyoshi OJI}

From the First Department of Medicine, Osaka University Medical School

(Director : Prof. T. Yoshida)

As reported previously, hyperfunction of pituitary-adrenal system often exists in diabetics especially in aged diabetics and in severe cases with ketosis. Such hyperfunction may be expected to aggravate the metabolic abnormalities of diabetes mellitus. Therefore, influence of various types of treatment such as insulin, mesoxalate, BZ 55, D 860 and phenethyldiguanide upon the urinary excretion of steroid hormones (17-OHCS and 17-KS) was studied. The influence of testosterone treatment was also studied.

1) In patients whose urine contains normal or less than normal amount of 17-OHCS, no appreciable change in the amount of steroid hormones was found following various types of treatment in spite of the decrease in urinary sugar.

2) In patients showing increased excretion of 17-OHCS;

a) Treatment using mesoxalate, BZ 55 and D 860 caused no marked change in the urinary excretion of 17-OHCS.

b) Phenethyldiguanide treatment caused marked decrease in the urinary excretion of 17-OHCS.

c) In patients treated with insulin, the urinary excretion of 17-OHCS and 17-KS decreased markedly.

d) In most cases treated with testosterone, urinary excretion of 17-OHCS decreased. However, in 2 cases, increase in the urinary excretion of steroid hormones and in urinary glucose was observed. 
正常ならびに歴代雌, 雄甲状腺機能異常ウサギより 生まれた子孫ウサギ $\left(\mathrm{F}_{1}, \mathrm{~F}_{4}, \mathrm{~F}_{5}, \mathrm{~F}_{6}\right)$ の甲状腺機能について

京都大学医学部病理学教室（指導 岡本耕造教授）

大学院学生山崎高明

目次

第 1 篇 正常ウサギの甲状腺機能について

I 緒 論

III研究材料と测定法扣よびその検討

A 研究材料扣よび飼育法

(1) 研究材料

（2）飼育法

B 测定法打よびその検討

(1) 血清 P B I 测定法

（2）血中総コレステロール測定法

（3）甲状腺 I ${ }^{131}$ 摂取率の測定法

III 测定值とその考案

（1）血清 P B I

（2）血中総コレステロール

(3) 甲状腺 $\mathrm{I}^{121}$ 葲取率

IV 結 論

第 2 篇 歴代雌，雄甲状腺機能異常ウサギよ り生まれた子孫（ウサギ $\mathrm{F}_{1} ， \mathrm{~F}_{4}$ ， $\mathrm{F}_{5}, \mathrm{~F}_{6}$ ）の甲状腺機能について

I 緒 論

II 研究材料执よび研究方法

A 研究材料扣よび飼育法
(a) 研究材料
（1）対照の正常ウサギ
（2）歴代雌，雄甲状腺末投与ウサギよ り生まれた子孫ウサギ $\left(\mathrm{F}_{1}, \mathrm{~F}_{4}\right.$, $\mathrm{F}_{5}, \mathrm{~F}_{6}$ )
(3) 甲末投与ウサギ
（4）厢代雌，雄甲状腺摘出ウサギより 生まれた子孫ウサギ $\left(\mathrm{F}_{1}, \mathrm{~F}_{4}\right)$
(5) 甲摘ウサギ
(b) 飼育法

B 研究方法

(1) 体重測定

（2）甲状腺機能検査法

III 研究成䋶

A 体重测定成績

(1) 正常ウサギ

(2) 甲末子孫ウサギ $\left(\mathrm{F}_{1}, \mathrm{~F}_{4}, \mathrm{~F}_{5}\right.$, $\mathrm{F}_{6}$ )

(3) 甲摘子孫ウサギ $\left(\mathrm{F}_{1}, \mathrm{~F}_{4}\right)$

B 血清 P B I 测定成績

（1）正常ウサギの血清 P B I 值

(2) 甲末子孫ウサギ $\left(\mathrm{F}_{1}, \mathrm{~F}_{4}, \mathrm{~F}_{5}\right.$, $\mathrm{F}_{6}$ ) の血清 P B I 值

（3）甲末投与ウサギの血清 P B I 值

（4）甲摘子孫ウサギ $\left(\mathrm{F}_{1}, \mathrm{~F}_{4}\right)$ の血清 P B I 值

（5）甲摘ウサギの血清 P B I 值

C 血中総コレステロール测定成縝

（1）正常ウサギの血中総コレステロー ル值

(2) 甲末子孫ウサギ $\left(\mathrm{F}_{1}, \mathrm{~F}_{4} \mathrm{~F}_{5}\right.$ ， $\left.\mathrm{F}_{6}\right)$ )の血中総コレステロール值

（3）甲末投与ウサギの血中総コレステ ロール值

（4）甲摘子孫ウサギ $\left(F_{1}, F_{4}\right)$ の血中 総コレステロール值

（5）甲摘ウサギの血中総コレステロー ル值

$\mathrm{D}$ 甲状腺 $\mathrm{I}^{131}$ 摂取率測定成縝

（1）正常ウサギの甲状腺 $I^{191}$ 摂取率测 定值

(2) 甲末子孫ウサギ $\left(\mathrm{F}_{1}, \mathrm{~F}_{4}, \mathrm{~F}_{5}\right.$, $\left.\mathrm{F}_{6}\right)$ の甲状腺 $\mathrm{I}^{131}$ 摂取率測定值

（3）甲末投与ウサギの甲状腺 $\mathrm{I}^{131}$ 摂取 率測定值

（4）甲摘子孫ウサギ $\left(\mathrm{F}_{1}, \mathrm{~F}_{4}\right)$ の甲状 

腺 $I^{131}$ 摂取率測定值
（5）甲摘ウサギの甲状腺 $I^{131}$ 摂取率測 定值
IV 考案
(1) 体重について
（2）各検查成績について
$\mathrm{V}$ 結 論
文 献

第 1 篇 正常ウサギの甲状腺機能について

\section{I 緒論}

\section{第 1 表 甲状腺機能検查法}
A) 物理的方法
1）基礎代謝率の測定
B）化学的方法
1）血清蛋白結合ヨード（P B I）の測定
2）血清総コレステロールの測定
3）尿中クレアチン，クレアチニンの测定
C) 物理化学的方法(放射性ヨードを用いる方法)
1) 甲状腺 I ${ }^{131}$ 楞取率
2) 尿中 $I^{131}$ 排泄率
3) 血獎中 I ${ }^{131}$ 交換率 (Conversi on ratio)
4) 甲状腺クリアランス

甲状腺機能検查法として一般に用いられているも のは第 1 表に示すようなものである.

1922年 Epstein ら ${ }^{20}$ は甲状腺疾患において脂質代 謝の異常をみ，そのなかでも特に血清総コレステロ 一ルの変化が著しいことを最初に注目した。一般に 甲状腺機能充進症では低く，機能低下症では増加す る場合が多いという.しかしとの血清総コレステロ 一ルおよび尿中クレアチン，クレアチニンの測定は いずれも非特異的なため，単に基礎代謝率に刘する 補助的なむのとして用いられていたにすぎない.

一万血中の甲状腺ホルモン量を研究してその機能 を知万うとする努力がなされてきた. すでに Baum$\mathrm{ann}^{7}$ ) (1895) が甲状腺中にヨードを証明し，その後

まもなく Oswald ${ }^{72)}$ が甲状腺からヨードを含んだ有効蛋白を抽出しててれを thyroglobulin と命名した. 次 いで1915年に Kendall ${ }^{45)}$ が甲状腺を加水分解してヨードを含んだ有效な結晶性化合体を抽出して thyroxine と名づけ，その後 Harington ${ }^{28)}$ がその化学的構造の決定に成功した. Means ら ${ }^{62)} 1940$ 年乾燥甲状腺末の活 性はその中に含有される thyroxine のみに比例せず全有機ヨードと並行することを明らかにし，狎状腺ホ ルモンは thyroxine と少量の他の有機ヨードとの総和と考光るのが妥当で，血中には遊離 thyroxine とし てではなく，蛋白と絬合して存在するものであり蛋白と共に沈降する(血清蛋白結合ヨードすなわち PBI) と 報告した. 事央 Danowski ${ }^{18)}$ (1950) によれば血中有機 ヨードの80〜90\%は thyroxine, 10〜20\%は non thyroxine であるという。最近 Gross ら ${ }^{24}$ は甲状腺ホルモンが組織に至つて作用を発腪するに当つては thyroxine のヨードが 1 個脱落して $3: 5: 3$-L-triiodothyronine となり, その効果を発現するといつている. このようにして Kendall ${ }^{46)}$ 以来血液中の甲状腺ホルモンを直接測定しようとして多くの学者達によつて不断

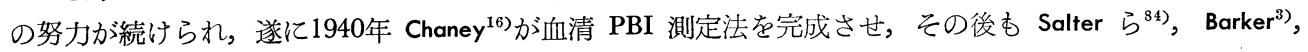
Connor $5^{17)}$ ，Grossmann $5^{25}$ の改良法が発表され，今日甲状腺機能検査法の一つとして主要な位置を占める ようになつた. 通常血清 PBI 值は甲状腺機能九進症では高く, 機能低下症では低いとされている.

次に放射性ヨードを用いる方法に関してみるに，1938年 Hertz ら ${ }^{31}$ がはじめててれをウサギに投与し，て

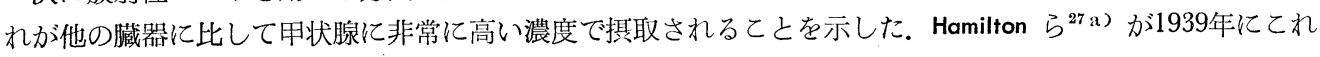
を臨床的に使用し甲状腺機能の観察を行つた．その後放射性ヨードが大量に生座されるようになるとともに， 乙れを用いて行う甲状腺機能の研究が盛んになり, その中でも特に甲状腺 $\mathbf{I}^{131}$ 摂取率は広く行われ多くの学者

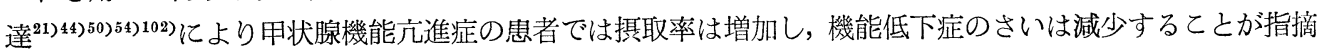
されている.

さていまウサギの甲状腺機能検查法についてみるに，ウサギについて基礎代謝率を測定することは難しく， Fleischmann ら ${ }^{22)}$ はウサギに甲状腺機能異常を起させてその血清総コレステロールの変動を観察しているが， 
一方サギの血清 PBI の測定については交献上その報告が少い。またウサギの甲状腺 $\mathrm{I}^{131}$ 摂取率の測定に関 しても $2 ， 3$ の報告をみるにすぎない，さらにウサギについて $2 ， 3$ 種類の甲状腺機能検查法をあわせ行つ た報告は全くみられない.

著者は次篇で述べる歴代雌，雄甲状腺機能異常ウサギより生まれた子孫ウサギの甲状腺機能の研究を企図 したのであるが，以上に述べた現況を考えあわせてウサギにおいても行うことができる血清 PBI および血 中総コレステロールならびに甲状腺 ${ }^{131}$ 掑取率を測定することを定め, その基礎部門として正常成熟ウサギの 雌，雄について血清 PBI，血中総コレステロール，甲状腺1 ${ }^{131}$ 掑取率の測定を行つたのでそれをここに報告し ようと考える。

\section{II 研究材料と測定法およびその検討}

\section{A 研究材料および趼育法}

\section{(1) 研究材料}

教室で妊娠分婏さして飼育した正常ウサギ(雌 6 匹，雄 6 匹，ウサギ番号：1１2)および業者より購入し 一定期間一定の食䭒で飼育した成熟ウサギ(雌 4 匹，雄 4 匹，ウサギ番号：13〜20)合計20匹で，体重2000 $3000 \mathrm{~g}$ のあの研究の対象とした，乙の中No. 5，No.10，No.11亿ついては生後90日より180日まで1 カ月 ごとに血清 PBI の測定を行つた。 なお甲状腺 ${ }^{131}{ }^{1}$ 摂取率の測定にはこの中から雙 6 匹，雄 6 匹の12匹を使用 した.

\section{(2) 趼育法}

これらの正常ウサギは飼料としてオカラ，カラスムギまたはオウムギを自由に与えた．幼少時には雑草を 投与したが，キャベッ，サッマイモヅル等の甲状腺腫誘発物質を含むと考えられるあのは絶対に与えないよ うにした．また冬季には煖房をなし常に一定条件のもとに飼育するように留意し，仔ウサギは生後40～50日 まで親ウサギとともに飼育し，その後は一匹ずつ個々の箱に移し上記の飼料で飼育した.

\section{B 測定法およびその検討}

\section{(1) 血清 PBI 測定法}

血清 PBI の測定法は1940年 Chaney ${ }^{16)}$ 亿よつて確立せられたが。これは Sandall \& Kalthoff ${ }^{82)}$ のセりウム 一亜吪酸系におけるョードの触媒作用を利用する微量ヨード測定法を応用したものである。乙の測定法は

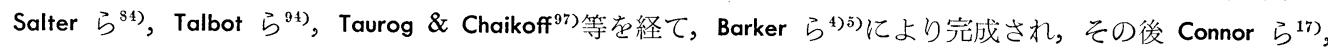
Grossmann \& Grossmann ${ }^{25)}$ がこれを更に改良して PBI 測定法も臨床検查法として広く行われるようになつた。 わが国でもいち早く Barker 定量法がとり入れられ，久保ら ${ }^{51)}$ ，田中 ${ }^{95} お$ おび田中ら ${ }^{96)}$ 等の報告がある.

PBI:定量法は有機ヨードを無機ヨードに変える方法によつて灰化法と蒸溜法とに分けられ，前者では温度 調節器付乾燥器や電気炉，熱電堆などのかなり大掛りな装置を必要とし，後者では破損しやすい特殊のガラ ス製芣溜器が必要であり，測定操作などあ加味して考えれば両者の得失は一長一短である.

以上種々の報告はヒトにおける PBI 測定法についてであり，ウサギのそれは内外飞 $2 ， 3$ みられるのみ

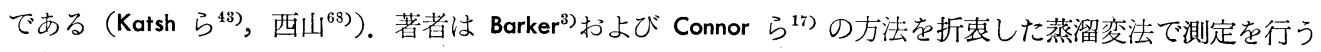
こととした.

(i) 測定原理

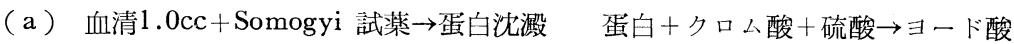
$\exists$ ヨド酸、瞢溜

(b) 比色過程

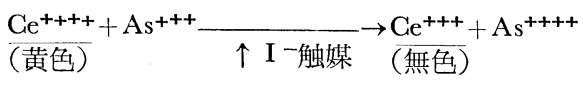

(ii) 試 薬 
試薬はすべて最純のものを使用し，再蒸溜水をむつて調製した。

(a) 再蒸溜水: 蒸溜水汇苛性力り約 $2 \sim 3 \%$ 割に加えて総ガラス製蒸溜水装置を用いて再蒸溜する.

(b) Somogyi 試薬

第 $\mathrm{I}$ 液 $: 12.5 \mathrm{~g} \mathrm{ZnSO}_{4} \cdot 7 \mathrm{H}_{2} \mathrm{O}$ を再蒸溜水に溶解し, これに $0.25 \mathrm{~N} \cdot \mathrm{H}_{2} \mathrm{SO}_{4} の 125 \mathrm{cc}$ を加え全量を $1 l$ 亿する。 第 I液 $: 0.75 \mathrm{~N} \cdot \mathrm{NaOH}$ 液 $: 30 \mathrm{~g}$ の $\mathrm{NaOH}$ を再蒸溜水溶解し, 全量を再烝溜水で $1 l$ とする.

第 $\mathrm{I}$ 液 $50 \mathrm{cc}$ 亿対し。第 II 液 6.7 6.8 ccを加えた時フェノールフタレイン指示楽を薄桃色にするよう第 II 液 の濃度を調製する。

(c) 硫酸溶液

$70 \% \mathrm{H}_{2} \mathrm{SO}_{4}$ : 垱蒸溜水 $600 \mathrm{cc}$ 亿濃硫酸780ccを加えて調製する。

$1 \mathrm{~N} \cdot \mathrm{H}_{2} \mathrm{SO}_{4}$ : 再蒸溜水 $900 \mathrm{cc}$ 亿濃硫酸 $28 \mathrm{cc}$ を加光, 冷却し再蒸溜水で $1 l$ 上する.

(d) $60 \% \mathrm{CrO}_{3}: 600 \mathrm{~g}$ 最純ク口ム酸を再蒸溜水汇溶解し, $1 l$ 亿する.

(e ) $0.75 \mathrm{~N} \cdot \mathrm{NaOH}: 30 \mathrm{~g}$ の $\mathrm{NaOH}$ を再蒸溜水汇溶解し, 全量を再萎溜水で $1 l$ とする.

(f) $50 \% \mathrm{H}_{3} \mathrm{PO}_{3}$ : 西燐酸結晶 $250 \mathrm{~g}$ を $200 \mathrm{cc} の$ 再蒸溜水溶解し, 時々再蒸溜水を加えて, 常に 400 5 70 ccに保ちつつ約 30 分間煮沸, 冷却後, 再蒸溜水で500ccとする.

（g） $30 \%$ 過酸化水素: $\mathrm{H}_{2} \mathrm{O}_{2}$ (特級)をそのまま使用する.

(h) $\mathrm{As}_{2} \mathrm{O}_{3}$ 試薬 : $1 \mathrm{~N} \cdot \mathrm{NaOH} 50 \mathrm{cck} \quad \mathrm{As}_{2} \mathrm{O}_{3} 3.17 \mathrm{~g}$ を加えよく溶解させた後200ccの再蒸溜水を加えて $70 \%$

第 $\mathbf{1}$ 図 Connor 型蒸溜器

(Connor ら ${ }^{17}$ 亿よる)

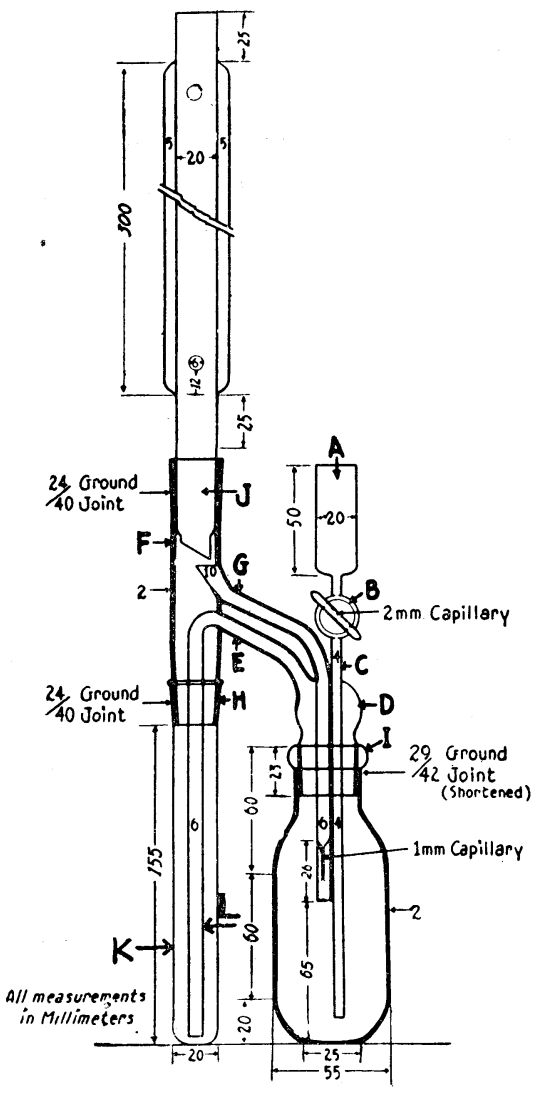

$\mathrm{H}_{2} \mathrm{SO}_{4}$ で中性とし(約 $2.5 \mathrm{cc}$ を要する), 後 $70 \% \mathrm{H}_{2} \mathrm{SO}_{4}$ を $54 \mathrm{cc}$ 加え，再蒸溜水で全量 $500 \mathrm{cc}$ とる。後に最純 $\mathrm{NaCl} 3.125 \mathrm{~g}$ を溶解して貯える.

(i) 硫酸セりウム試薬: $\mathrm{Ce}\left(\mathrm{SO}_{4}\right) \cdot 2\left(\mathrm{NH}_{4}\right)_{2} \mathrm{SO}_{4} \cdot 2 \mathrm{H}_{2} \mathrm{O}$ （米国 Frederick Smith 会社製）12g $3.5 \mathrm{~N} \cdot \mathrm{H}_{2} \mathrm{SO}_{4} 500 \mathrm{cc}$ 亿溶 解する。

（j） ヨード標準液：純品の NaI を充分乾燥し, $118.1 \mathrm{mg}$

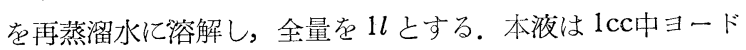
100 个含み，貯藏液として褐色瓶に入れ泠喑所に保存し。こ の一部をとり 1 cc中 $0.04 \gamma$ のヨードを含有するようにうすめ, 測定時の規準液とする。

(iii) 器 具

(a) Connor 型蒸溜器 (第 I 図参照).

(b) 遠心管, 平底試験管等.

（c）比色計：光電比色計（島津DF-II 型）を用い Filter は $450 \mathrm{~m} \mu$ を使用した。

(iv）実施方法：乙れを各段階に大別すると（a 除蛋白お よび水洗，(b)酸化，(c)蒸溜，(d)比色，(e)計算の5つ に分けられる。なお採血は早朝慨投与前に耳静脈より行い。 遠沈後その血清1.0ccを使用した。

(a) 血清の除蛋白および洗涤

血清1.0ccを50cc容量の丸底遠沈管にとりこれに Somogyi 試薬第 I 液 8cc?又第 II 液 $1 \mathrm{cc}$ を加光，攪拌棒をるつてよく混 和した後約 $5 \sim 10$ 分間放置後 2000 回転10分間遠沈し，上清を 捨てる. 乙の沈渣に再苲溜水10ccを加え攪拌後再び遠沈し上 清を捨てる。ささらに同様の操作を 1 回繰り返す。次いで $5 \mathrm{cc}$ 第 35 巻 第 9 号 
の70\% $\mathrm{H}_{2} \mathrm{SO}_{4}$ を管壁を洗いながら加え，充分に沈渣を専用攪拌棒で混ぜて溶解してれを酸化コルベンに移す． さらにもう 1 回 $70 \% \mathrm{H}_{2} \mathrm{SO}_{4} 5 \mathrm{cc}$ を加え同様操作を行い，最後に $5 \mathrm{cc}$ 再蒸溜水で管壁をよく洗つて，完全に 沈渣を酸化コルベンに移してしまう。

(b) 酸 化

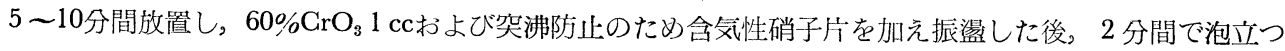
程度の火焰で 5 分間熱した後室温に約 10 分間放冷する。次に再蒸溜水 $15 \mathrm{cc}$ をコル゙ンに加え，再び白煙がコ

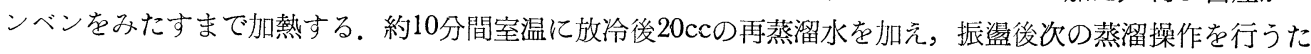
めにコルベンを蒸溜器に連結する。

(c) 蒸 溜

蒸溜器の $\mathrm{K}$ 管に $0.75 \mathrm{~N} \cdot \mathrm{NaOH}$ 液 $0.5 \mathrm{cc}$ をれ，乙れを連結した後ビュレット挾をもつて固定しまず冷却 器に水を通しておき，次いで漏斗の活栓 $\mathrm{B}$ を閉じ小火焰て酸化コルベンを加熱すると溜液が㠜縮して酸化コ ルベン連結部の上部よりコルベン内の液の一部が導管 $\mathrm{C}$ を上昇してくる。次に漏斗 $\mathrm{A}$ 亿 $50 \% \mathrm{H}_{3} \mathrm{PO}_{3}$ 液 $5 \mathrm{cc}$

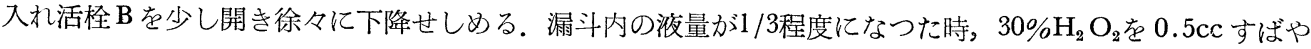
く加えた後，活栓 B を全開し注入し，注入し終れば直ちに活栓を閉じる．次いで約 $2 \mathrm{cc} の$ 再蒸溜水を漏斗内 に入れ再び活栓を開き試薬を完全にコルベン中に洗い落した後直ちに閉じる．次に約10分間コルベンを加熱 し発生する分子ヨードをアルカリ液を入れたK管に補足した後（大体蒸溜液が8.5cc位になつた時）（管を連 結部よりはずしてから加熱を中止し冷却する，次に導管Lを少量の再蒸溜水で洗いこれを $\mathrm{K}$ 管に受け水中で 冷却後 $1 \mathrm{~N} \cdot \mathrm{H}_{2} \mathrm{SO}_{4} 1 \mathrm{cc}$ を加光，目盛(10cc)まで再蒸溜水を加えた後，上く振湓混和する。

(d) 比色

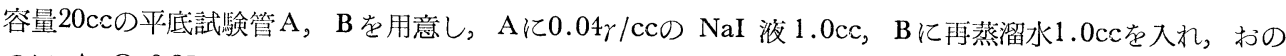
おのに $\mathrm{As}_{2} \mathrm{O}_{3} 0.25 \mathrm{cc}$ および前記操作で得られた蒸溜液各 $2.5 \mathrm{cc}$ 追加し，振湓後 $37^{\circ} \mathrm{C}$ 恒温槽中に入れ，約 10 分後 $\mathrm{A}$ 亿硫酸セりウム液 $0.5 \mathrm{cc}$ を加える。乙れを直ちに良く振盪してキュベットに移し恒温槽に入れる。

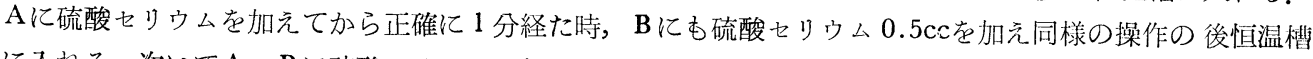
に入れる。次いでA，B硫酸セリウムを加えてから正確にそれぞれ 6 分目, 12分目に光電比色計 (島津DF一 II 型)により $450 \mathrm{~m} \mu$ の Filter を用いて吸光度を測定する。

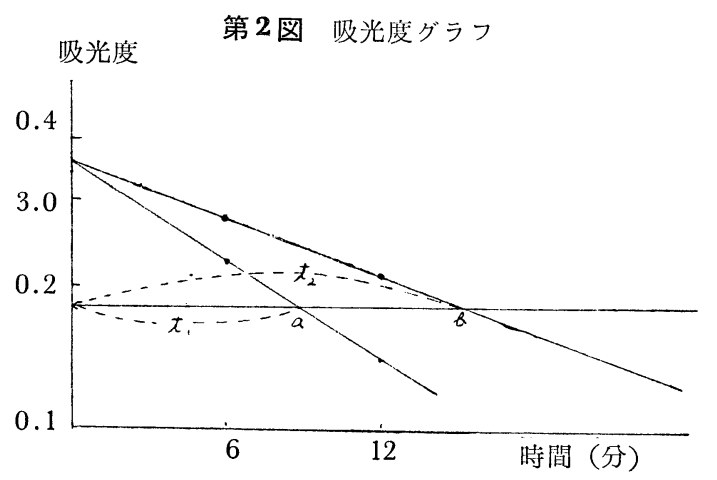

cc中におけるヨード量は次の式で求められる. （e 計算 (第 2 図参照)

半対数グラフ上に吸光度を，時間を横軸に上る 上第 2 図のように0 分で交文する 2 つ直線が得 られる，次に任意の横線を引き，2直線と交叉す る点を $\mathrm{a} ， \mathrm{~b}$ とし，縦軸から $\mathrm{a} ， \mathrm{~b}$ までの時間を $\mathrm{t}_{1}$ および $\mathrm{t}_{2}$ とすると（ $\mathrm{t}_{1}$ および $\mathrm{t}_{2}$ が整数となるよ うに横線を引く）， B 中のすなわち未知液中のヨ 一ド量は $\frac{0.04 \times \mathrm{t}_{1}}{\mathrm{t}_{2}-\mathrm{t}_{1}} \gamma$ で表わされる. しかし試薬中 に含まれる微量のヨードおよびセりウムの反応に 影響するむのを示す盲験值 C を堫引いて血清 100

$$
\frac{10}{2.5} \times 100\left(\frac{0.04 \times \mathrm{t}_{1}}{\mathrm{t}_{2}-\mathrm{t}_{1}}-\mathrm{C} / \mathrm{r} / \mathrm{dl}\right.
$$

Gの值は試薬を新たに調製した時に測定すればよく，著者の場合 $\frac{10}{2.5} \times 100 \times \mathrm{C} の$ 值は $1.4 \gamma / \mathrm{dl}$ であり，

Barker ら5)の3.5〜3.9 $/ \mathrm{dl}$ ，七条ら ${ }^{87}$ の $2.3 \gamma / \mathrm{dl}$ とほぼ同様の值を示している.

標準グラフを用いずに，このように面倒な方法をとるのは次の理由による。すなわちこのセりゅムの反応 は種々の物質，特に塩類の影響を受けるため，単に種々な濃度のヨード液をセりウム，亜比酸液に加えて作 
第 2 表 回収試験成績

(その一部)

\begin{tabular}{c|c|c}
\hline $\begin{array}{c}\text { 添加量 } \\
r\end{array}$ & $\begin{array}{c}\text { 回収量 } \\
r\end{array}$ & $\begin{array}{c}\text { 回収率 } \\
\%\end{array}$ \\
\hline \hline 0.10 & 0.093 & 93.0 \\
0.10 & 0.091 & 91.0 \\
0.05 & 0.047 & 94.0 \\
0.05 & 0.046 & 92.0 \\
0.025 & 0.024 & 96.0 \\
0.025 & 0.023 & 92.0 \\
\hline
\end{tabular}

第 3 表 平行試験成䋶 (その一部)

\begin{tabular}{c|cc|c}
\hline \hline 番号 & 血清 & $(\gamma / \mathrm{dl})$ & 差 $(r / \mathrm{dl})$ \\
\hline \hline 1 & 3.7 & 3.9 & 0.2 \\
2 & 4.8 & 5.2 & 0.4 \\
3 & 6.4 & 6.9 & 0.5 \\
4 & 9.6 & 9.8 & 0.2 \\
\hline
\end{tabular}

つた標準グラフを用いると血清中の真の值よりは幾分高い值を示すとされ ている。 また試薬の盲験值が変化する場合むあり，恒温槽の温度が正確に 一定に保ち難い事等による。

なお測定法の正確度を知る目的で，種々の濃度の KI 液を蒸溜法で測定 した回収率は平均 $93 \%$ を示し(第 2 表), 田中ら ${ }^{96)}$ の行つた Connor 変法で の回収率 92〜100\%とほぼ一致している。ささらに血清を用いた平行試験に おける 2 本の試料の差は $0.2 \sim 0.5 \gamma / \mathrm{dl}$ であつた(第 3 表).

(v) 測定上の注意

（a）測定室において分子ヨードその他セりウム，亜比酸の反応に影響 するオスミューム，水銀，銀，口攵塩，クエン酸塩，青化物等は取扱わ ないようにした。

（b）採血する注射器および採血用試験管は再蒸溜水で洗袮乾燥し たものを用いた。

（c）ガラス器具は使用後クローム硫酸液中に浸し，水道水で充分 に, さらに再蒸溜水で $3 \sim 4$ 回洗涤, 乾燥して用いた. 特に Connor 型蒸溜器の取扱いには破損せぬよう充分の注意が必要である.

\section{（2）血中総コレステロール測定法}

これには種々の方法があるが，Bloor ${ }^{10}$ 氏定量法を改良した光電比色

定量法 ${ }^{41)}$ 用いた。

(i) 原 理

血液あるいは血槳をアルコール・エーテル混合液でコレステロールを抽出し，てれを蒸発して残渣をクロ ロホルムに溶解させ，無水醋酸および濃硫酸を加えて生じた緑色（Liebermann-Burchard 氏反応）を同様に 処理したコレステロール規準液と比色定量する.

(ii) 試 薬

（a）Bloor 氏試薬：95\%エチルアルコール(特級) 3 容とェーテル(特級) 1 容とを混ずる.

(b) クロロホルム(特級).

（c）無水醋酸・硫酸混液：10.0 c cのメスチリンデルに無水醋酸(特級) $10.0 \mathrm{ccc}$ 入れ，乙れに濃硫酸 (特 級)1.0ccを徐々に加え，転倒混和，冷水につけ室温に冷却。10分以内に使用のこと.

第3図コレステロールの標準曲線

島津光電比色計DF- II 型，Filter $634 \mathrm{~m} \mu$ $\left(27^{\circ} \mathrm{C}\right.$ 温浴中 10 分, 後水道水 $\left(15^{\circ} \mathrm{C}\right)$ 中に 5 分 $)$

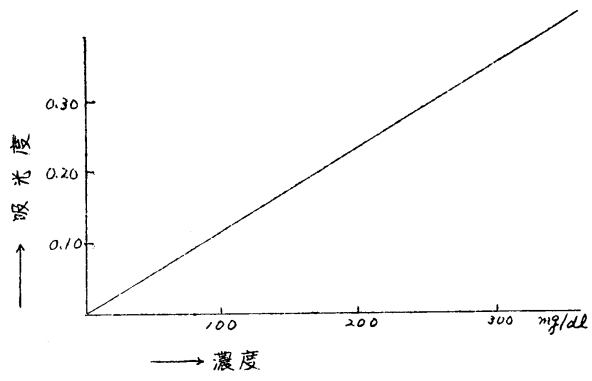

(d) コレステロール規準液：純コレステロール $\left(\mathrm{C}_{27} \mathrm{H}_{45} \mathrm{OH}\right)$ 0.100g t100ccのメスコルベンに入れ， クロロホルムを加えて溶加し100 ccとする $(1 \mathrm{cc}=1 \mathrm{mg}$ コレステロール). とのさい室温を記入しておき，常 そその温度にして用いる。

(iii) 実 施

コレステリン管に Bloor 氏試薬 $12 \mathrm{cc}$ を入れ，乙れ に早朝餌投与前採血した全血 $0.2 \mathrm{cc}$ を管を振蕰しつつ 滴下し，栓をほどこしてはげしく 1 分間振擝した後, 30分間栓をしたまま管を放置する。次いで2000回転で 5 分間遠沈し，上清をできるだけ完全に30cc容コルベ ンに移し，温湯上で蒸発乾涸する。乾固したならば直 ちに温湯上より取り去り，温いうちに少量のクロロホルムを 3 回に分けて残渣に加え溶解させ，乙れを別の コレステリン管に完全に移す．冷却後正確に10ccの目盛までクロロホルムを追加する. 他のコレステリン管 にクロロホルム $10 \mathrm{cc}$ より盲験液とする。おのおのへ新しく調製して放泠した無水醋酸，硫酸混液 $2.0 \mathrm{cc}$ を 
加える。栓をほどしして $27^{\circ} \mathrm{C}$ の温浴中に 10 分間放置し，次いで栓をしたまま水道の流水中に 5 分間つけ冷却 させる.

光電比色計(島津DF- II 型) で $634 \mathrm{~m} \mu$ の Filter を用い，盲験液の透化率を $100 \%$ に合わせ，被験液の财光度 を求內，あらかじ作つておいた標準曲線よりその濃度を算定する(第 3 図).

(iv) 註

普通コレステロール定量は血漿(清)について行われるが，著者は全血を用いた。 これは同時に PBI の測 定む行わねばならず多量の採血によるウサギの衰弱をおそれたたためである.

第 4 図 ウサギの甲状腺 $\mathrm{I}^{13}$ 搯取率測定方法

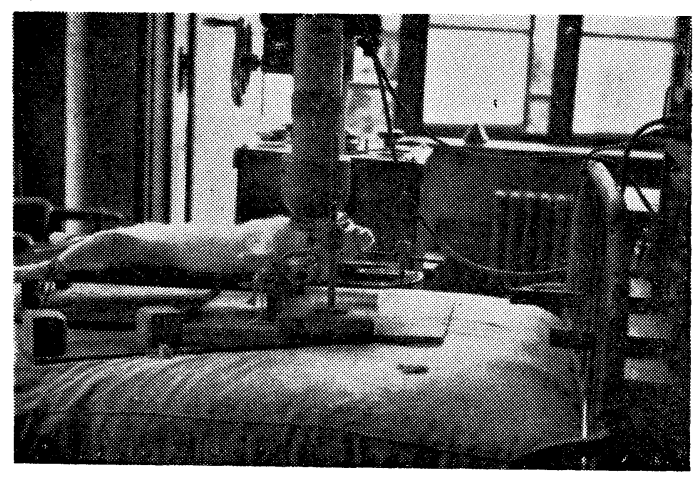

\section{（3） 甲状腺 ${ }^{131}$ 摂取率の測定法}

Hertz ら ${ }^{31)}$ が1938年初めて放射性ヨードを ウサギに投与し，てれが他の藏器に比して甲状 腺に著明住合するととを観察し，翌1939年に は Hamilton $ら^{27 \mathrm{a})}$ が臨床的にてれを使用し，甲 状腺機能の観察を行つた。 その後次第に広く用 いられるようになり，測定法に関する研究む重 ねられ, Fields $ら^{21)}$, Reid $ら^{79)}$, Brownel $ら^{12)}$ の報告があるが，それぞれの装置によりそれぞ れの測定を行いかつ補正をしており，今日なお 統一されていない，著者は Fields ら ${ }^{21)}$ の方法に 準じ次のように行つた(第 4 図参照).

$\mathrm{NaI}^{131}$ (日本放射性同位元素協会より分配されたもの)を蒸溜水 $0.5 \mathrm{cc}$ 中に $10 \mu \mathrm{c}$ 含まれるように溶かして，ウ サギの耳静脈より注射し，その後 $1,3 ， 6 ， 12 ， 24 ， 48 ， 72$ 時間目に甲状腺部位の体表上に，中央に直径 3.2

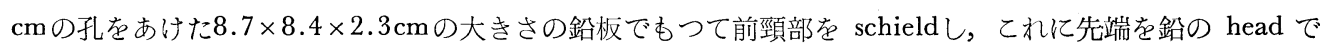
おおつた Scintillation Counter (E.K. Cole LTD, Power Unit Type 1033A, Scaler Type N526, made

第表表正常ウサギの血清 P B I 扔よび 血中総コロステロール測定成績

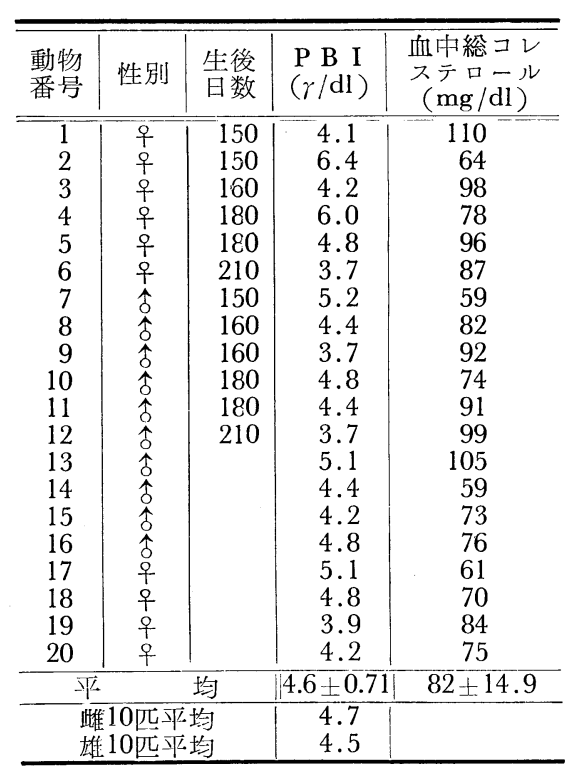

in England) を密着させ, $\gamma$ 線についてその計数を測定し， 対照(蒸溜水 $0.5 \mathrm{cc}$ K NaI ${ }^{131} 10 \mu \mathrm{c}$ を溶汃儿小金属峛に入れ, 赤燈ランプで徐々に乾燥させたもの) の計数との比率を求 わた。 なお 24 時間值までは大腿下部の計数を測定し，補正 を行い，自然計数として大気中の計数を用いた.

$\frac{\text { 甲状腺部位の計数- }- \text { 大腿下部の計数 }}{\text { 投与量 } \mathbf{I}^{131} \text { 計数一自然計数 }} \times 100$

\section{III 測定值とその考察}

\section{(1) 血清 $\mathrm{PBI}$}

雌10匹，雄10匹の正常成熟ウサギにおける 血清 PBI 倠 は第 4 表に示す通りである。雌10匹の平均値は $4.7 \gamma / \mathrm{dl}$ で あり。雄10匹の平均值は $4.5 \gamma / \mathrm{dl}$ で両性間には活とんど差 はみっとられない。これはヒトにおいて観察した Rapport

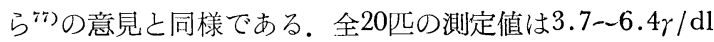
の範囲で平均 $4.6 \pm 0.71 \gamma / \mathrm{dl}$ である.

ウサギの血清 PBI 值に関しては，Katsh ら ${ }^{43}$ は 4 匹測定 して $3.3 \pm 0.5 \gamma / \mathrm{dl}$ 上報告し，わが国では西山 ${ }^{68)}$ が 5 匹測定 して3.3 6.0 \%/ $\mathrm{d} 1$ と発表しているにすぎない. これらの報 告はいずれも少数例の測定であり，方法も異つているが。 
第 5 表 正常ウサギの年令別血清 P B I 測定成績 $(r / \mathrm{dl})$

\begin{tabular}{|c|c|c|c|c|c|}
\hline $\begin{array}{l}\text { 動物 } \\
\text { 番号 }\end{array}$ & 性別 & $\begin{array}{l}\text { 生後 } \\
90\end{array}$ & 120 & 150 & 180 \\
\hline 5 & 우 & 4.4 & 4.0 & 4.6 & 4.8 \\
\hline 10 & $\hat{\jmath}$ & 4.0 & 4.6 & 4.4 & 4.8 \\
\hline 11 & 今 & 4.2 & 4.0 & 4.4 & 4.4 \\
\hline
\end{tabular}

著者の測定值むほぼてれらに近い值を示している。また 3 匹 の正常ウサギについて生後90日から180日に至るまでその血 清 PBI を 1 カ月でとに測定して第 5 表に示した。 幼少時に おける值はいずれも成熟ウサギの值の正常範囲内にあり，生 後日数とともに変化する血清 PBI 值の门もそれ程大ではな い. これもヒトにおける Man ら ${ }^{56)}$ ，Talbot ら ${ }^{94)}$ の報告之一 致している。

（2）血中総コレステロール

雌，雄各10匹の正常成熟ウサギの血中総コレステロール值は第 4 表に示した通りで $59 \sim 110 \mathrm{mg} / \mathrm{dl}$ の範囲 で平均 $82 \pm 14.9 \mathrm{mg} / \mathrm{dl}$ である.

ウサギの血中総コレステロール值については，Member ら ${ }^{63)}$ は全血で $71 \sim 134 \mathrm{mg} / \mathrm{dl}$ ，平均 $100 \mathrm{mg} / \mathrm{dl}$, Fleischmann ら ${ }^{22)}$ は血清で 40－100 mg/dlなどと報告している．血清より全血の方が高值を示すようであり， 著者の測定值は全血であるが。 Member らの報告より多少低值を示している.

\section{(3) 甲状腺の $I^{131}$ 摂取率}

雌 6 匹，雄 6 匹の正常成熟ウサギの甲状腺 $\mathrm{I}^{131}$ 掑取率の測定值は第 6 表および第 5 図に示す通りである. 雌 6 匹の平均值は， $\mathrm{NaI}^{131}$ 注射後 1 時間值 : 23.7\%，3 時間值 : $32.7 \% ， 6$ 時間值 : $35.3 \%$ で最高值を示し, 12時間值 : $24.4 \% ， 24$ 時間值 : 16.3\%，48時間值 : $9.5 \%$ 之減少し，72時間值 : $7.2 \%$ あるあ。雄 6 匹の平均 值は $\mathrm{NaI}^{131}$ 注射後 1 時間值 : $19.9 \% ， 3$ 時間值 : $26.2 \%$ で最高值を示し，その後は 6 時間值 : $25.7 \% ， 12$ 時間值 : $19.6 \% ， 24$ 時間值 : $15.2 \% ， 48$ 時間值 : $13.3 \%$ と減少し,72時間値 : 9.9\%である. 24 時間值までは 雌の平均值の方が高值を示すが，その後48，72時間值は雄の方が高い. Perlmutter \& Riggs ${ }^{74}$ はヒトの摂取率

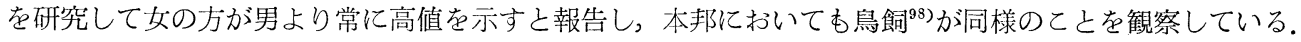

全12匹の平均值は $\mathrm{NaI}^{131}$ 注射後 1 時間值 : $21.8 \pm 10.4 \% ， 3$ 時間值 : $29.5 \pm 8.8 \%$ と高くなり，6時間 值 : $30.5 \pm 8.8 \%$ と最高值を示し，その後は 12 時間值 : $22.0 \pm 6.7 \% ， 24$ 時間值 : $15.7 \pm 5.6 \% ， 48$ 時間值 : $11.4 \pm 6.8 \%$ とぜんじ減少し，72時間值は $8.5 \pm 5.5 \%$ ある。乙のさい各時間值とも個体差がみられ，かな

第 6 表 正常ウサギの甲状腺 $\mathrm{I}^{131}$ 摂取率測定成績 $(\%)$

\begin{tabular}{|c|c|c|c|c|c|c|c|c|c|}
\hline $\begin{array}{l}\text { 動物 } \\
\text { 番号 }\end{array}$ & 性別 & 生後日数 時間 & 1 時 間 & 3 時 間 & 6 時 間 & 12 時 間 & 24 時 間 & 48 時 間 & 72 時 間 \\
\hline 1 & 우 & 160 & 13.5 & 30.0 & 28.2 & 16.0 & 11.1 & 11.5 & 5.7 \\
\hline 2 & 우 & 160 & 25.9 & 35.5 & 49.7 & 34.2 & 20.3 & 15.5 & 11.9 \\
\hline 3 & 우 & 180 & 32.8 & 35.5 & 39.8 & 18.5 & 13.2 & 5.7 & 1.6 \\
\hline 4 & 우 & 190 & 23.8 & 32.1 & 35.2 & 29.3 & 15.3 & 6.8 & 2.9 \\
\hline 7 & 占 & 160 & $6 \cdot 9$ & 19.2 & 28.8 & 26.5 & 25.3 & 22.6 & 16.0 \\
\hline 8 & 占 & 180 & 39.7 & 37.8 & 35.6 & 27.6 & 15.3 & 11.1 & 10.6 \\
\hline 10 & 今 & 190 & 26.1 & 36.1 & 27.7 & 11.7 & 6.5 & 1.3 & 0.4 \\
\hline 11 & 今 & 190 & 18.9 & $28 \cdot 2$ & 27.2 & 23.2 & 12.7 & 4.9 & 2.1 \\
\hline 15 & $\hat{\delta}$ & & 4.1 & 7.2 & 12.6 & 13.4 & 15.0 & 15.5 & 12.9 \\
\hline 16 & 今 & & 23.9 & 28.4 & 22.4 & 15.2 & 16.1 & 24.3 & 17.2 \\
\hline 17 & 우 & & 34.4 & 43.0 & 30.8 & 19.0 & 10.9 & 5.3 & 10.1 \\
\hline 18 & 우 & & 11.6 & 20.0 & 28.0 & 29.4 & 26.7 & 12.3 & 10.8 \\
\hline & 平 & 均 & $|21.8 \pm 10.4|$ & $29.5 \pm 8.8$ & $30.5 \pm 8.8$ & $22.0 \pm 6.7$ & $15.7 \pm 5.6$ & $11.4 \pm 6.8$ & $8.5 \pm 5.5$ \\
\hline & 雌 6 & 元平均 & 23.7 & 32.7 & 35.3 & 24.4 & 16.3 & 9.5 & 7.2 \\
\hline & 雄: 6 & ; 匹平均 & 19.9 & 26.2 & 25.7 & 19.6 & 15.2 & 13.3 & 9.9 \\
\hline
\end{tabular}


第 5 図 正常ウサギの甲状腺 $\mathrm{I}^{131}$ 摂取率測定成績 $(\%)$

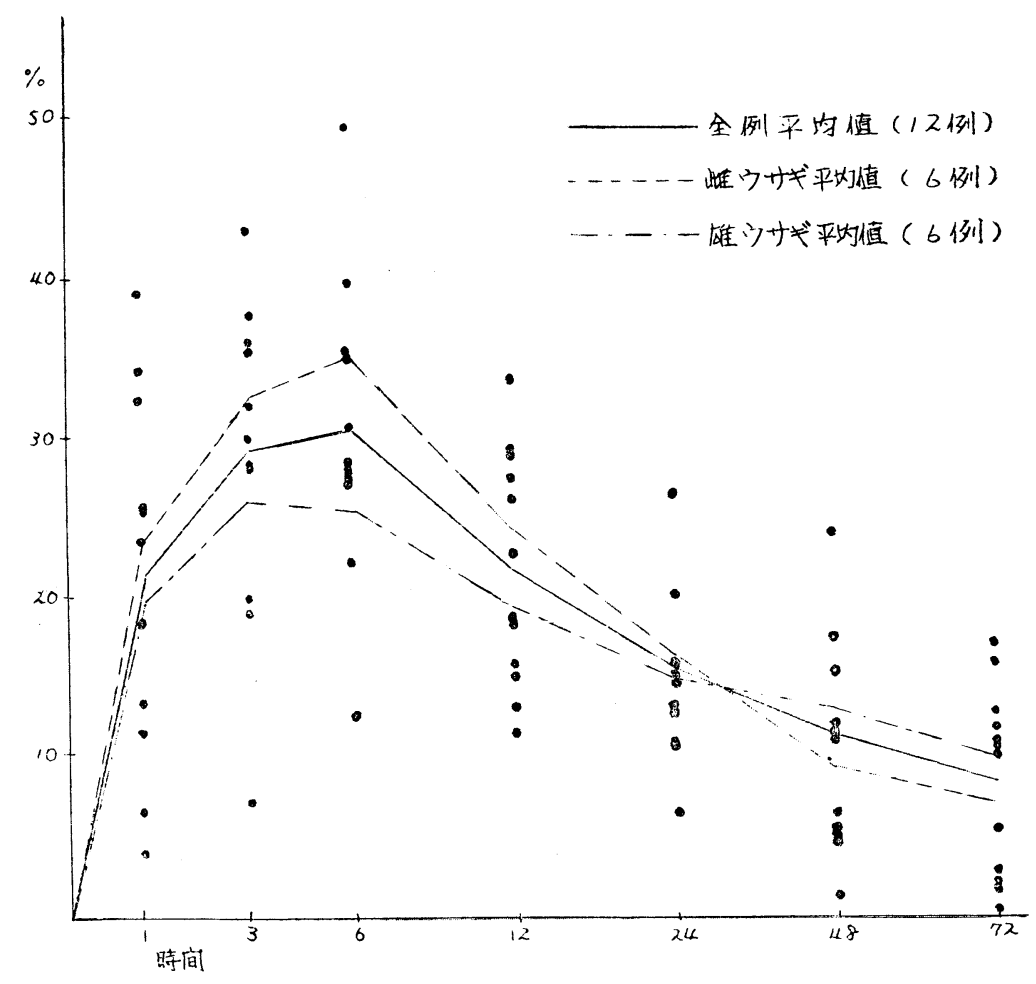

り川のある值を示している.

ウサギの甲状腺 $\mathrm{I}^{131}$ 掑取率に関しては入江 ${ }^{38)}$ ，倉持 ${ }^{52)}$ が 6 匹について测定を行い. 平均值として 3 時間值 : $50.0 \pm 14.9 \% ， 6$ 時間值 : $44.3 \pm 10.1 \% ， 12$ 時間值 : $39.3 \pm 12.9 \% ， 24$ 時間值 : $27.5 \pm 15.3 \%$ ，48時間值 : $22.7 \pm 7.0 \%$ 挙げているが，著者の測定值より高く出ているのは測定方法の相違が一因をなしているも のと考えられる。しかし各時間値に门のあるととは，著者の報告と同様である.

\section{IV 結 論}

体重2000 3000gの正常成熟ウサギ雌10匹，雄10匹における血清 PBI を Barker 法および Connor らの方 法を折衷した弥溜変法で測定し，血中総コレステロールをBloor 氏変法で定量し，さらに雌 6 匹，雄 6 匹に ついて甲状腺 $\mathrm{I}^{131}$ 摂取率を Fields 法に準じて測定を行い，次の結果を得た。

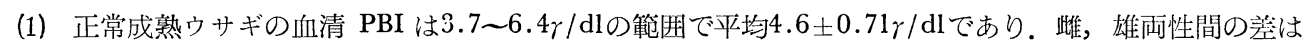
ほとんどみとめられない．また生後日数にともなう血清 PBI の変化はそれ程大ではない.

（2）正常成熟ウサギの血中総コレステロール值は $59 \sim 110 \mathrm{mg} / \mathrm{dl}$ の範囲に分布し, 平均值は $82 \pm 14.9 \mathrm{mg} / \mathrm{dl}$ である.

(3) 正常成熟ウサギ12匹の甲状腺 $\mathbf{I}^{131}$ 揕取率の平均值は， $\mathrm{NaI}^{131}$ 注射後 1 時間值 : $21.8 \pm 10.4 \%, 3$ 時間 值 : $29.5 \pm 8.8 \% ， 6$ 時間值 : $30.5 \pm 8.8 \% ， 12$ 時間值 : $22.0 \pm 6.7 \% ， 24$ 時間值 : $15.7 \pm 5.6 \% ， 48$ 時間值 : $11.4 \pm 6.8 \% ， 72$ 時間值 : $8.5 \pm 5.5 \%$ であり，各時間值とも相当巾のある值を示している. なお雌 6 匹の平 均值は雄 6 匹の平均值に比し，24㭙間值までは高值を示すが，その後は雄より低い值を示している.

(文献後出) 
第 2 篇 歴代雌, 雄甲状腺機能異常ウサギより生まれた 子孫ウサギ $\left(\mathrm{F}_{1}, \mathrm{~F}_{4} \mathrm{~F}_{5}, \mathrm{~F}_{6}\right)$ の甲状腺機能について

\section{I 緒 論}

甲状腺疾病の発症には古くから遺伝的因子や素因などが重要視されてきている。まず，Mackenzie ${ }^{55)}(1890)$ は 2 代の同一家系に扔いて 12 人の Basedow 氏病の発病を報告し，Morrison ${ }^{64}(1928)$ は 2 代の間に同一家族 6 人, $\operatorname{Martin}^{58}(1939)$ は同じく 7 人の Basedow 氏病の患者の発生を報告し，最近Boas \& Ober ${ }^{11)}(1946)$ 屯同様 の観察を行いての発症に遺伝がある程度関与しているととを示しており，先天性甲状腺機能九進症に関する 報告す $2 ， 3$ みられる ${ }^{53388)}$. また White ${ }^{104}$ (1912)は Basedow 氏病の母親より生まれた児の甲状腺に機能立 准像をみとめ，木邦においても高橋 ${ }^{93}$ (1928)は同様の報告を行つており，その他佐々木ら ${ }^{85)}(1955)$ や金地ら

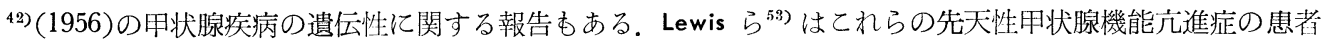
について甲状腺機能検查を行い，臨床的にあ検査成績からあ機能九進状態を示しているととを観察した。

一方機能低下症については，Hubble ${ }^{35}$ は 4 人の家族性クレチン症の発症を報告し, Bernheim ら ら $^{87}$ 先天性粘 液水腫の研究を行い，その 9 人において父母の甲状腺機能異常をみとめている．また一方 Koerner ${ }^{48)}$ は甲状 腺機能低下状態の母体加ら機能立進症の児の分娩を報告しており，Carr $ら^{13}$ は一般的に母体の甲状腺機能低 下症は特発性の胎児の機能低下症の原因ではないといつており，一定の意見が得られていない．

これらにやや関係のある実験的研究として動物に甲状腺機能充進症を起させて，胎仔むしくは新生仔にお よばす影響についての研究が先人によつて報告されており2334)377719371077108)，また甲摘が新生仔動物におよば

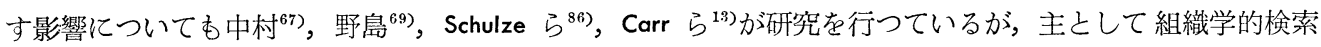
で機能的観察を行つたものはみられない，乙れらはいずれも妊娠期間中の母体の甲状腺機能異常がその胎仔， あしくは新生仔におよばす影響(胎生環境の影響)についての研究であつて，弤娠前の甲状腺機能異常がその 仔におよばす影響について観察し，さらに経代的にその影響を研究しているものはみられない.

最近岡木教授 ${ }^{70 a}$ a 70 b) は歴代雌, 雄ウサギに Alloxan 糖尿病を発症させその交配により生まれた子孫ウサ ギの膵藏 Langerhans 氏島の $\beta$ 細胞に累代性に增強する発育障害のあることを明らかにし，一定年令に達し た $\mathrm{F}_{4}, \mathrm{~F}_{5}$ ウサギの全例において糖尿病の自然発症を来たすととを報告しているし，またそのさいい起る $\beta$ 細 胞の発育障害は胎生期の影響ではなくて両視ウサギの糖尿病環境が生殖細胞に影響して起るあのであるとい う興味ある結論に到達している ${ }^{70 c)}$.

これらの実験結果が甲状腺疾病にも適合するのではなからうかとの考劣から倉持 ${ }^{52}$ は妊娠前に歴代雌，雄 ウサギに甲状腺機能九進状態を，入汇 ${ }^{38}$ は機能低下状態を起させ，その子孫ウサギ $F_{1}, F_{2}, F_{3}$ について研究 し，前者では累代性に増強する甲状腺機能立進像を，後者では同様の機能低下像をみとめたと報告した。

著者はこの研究をさらに進め，代を重ねて子孫ウサギ $\mathrm{F}_{4}, \mathrm{~F}_{5}, \mathrm{~F}_{6}$ ウサギを得，また $\mathrm{F}_{1}$ ウサギを作り，乙 れらのウサギの甲状腺機能を研究することによつて, 甲状腺疾病の遺伝や先天性素因の問題に新しい知見を 加えるのではなからうかと考えて，血清 PBI，血中総コレステロールならびに甲状腺 $\mathrm{I}^{131}$ 摂取率の測定を行 つた。そしてその結果を対照の正常ウサギ，甲状腺末投与ウサギおよび甲状腺摘出ウサギなどの值と比較研 究し一定の成績を得たのでここに報告する次第である.

\section{II 研究材料及び研究方法}

\section{A 研究材料および飼育法}

\section{(a) 研究材料}

(1) 対照の正常ウサギ

対照として実験に使用した正常ウサギは第 1 篇報告のあのと同一で，すなわち教室で妊娠分娩さして飼育 したもの 12 匹，生後日数不明の成熟ウサギを業者より購入し，一定期間一定の食餉で飼育したすの 8 匹の 
合計20匹である. これら全部について血清 PBI, 血中総コレステロールを測定し，この中の12匹について甲 状腺 $\mathbf{I}^{131}$ 摂取率の測定を行つた。

後述のように正常ウサギの雌No. 1, No. 2 上雄No. 7 の 3 匹にはチラジン末を与え, 同しくく雌 No. 3 上 雄 No. 8 は甲状腺摘出を行い，それぞれ仔ウサギ $\left(\mathrm{F}_{1}\right)$ を得た。なお別に教室で弤娠分婏さした正常ウサギ 22 匹について幼時より成熟時まで体重測定を行つて実験ウサギの対照とした。

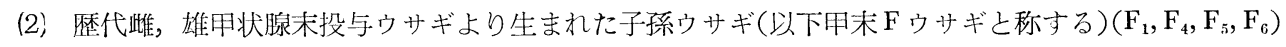

第 7 表(a) 甲末 $\mathrm{F}$ ウサギ系譜（その1）
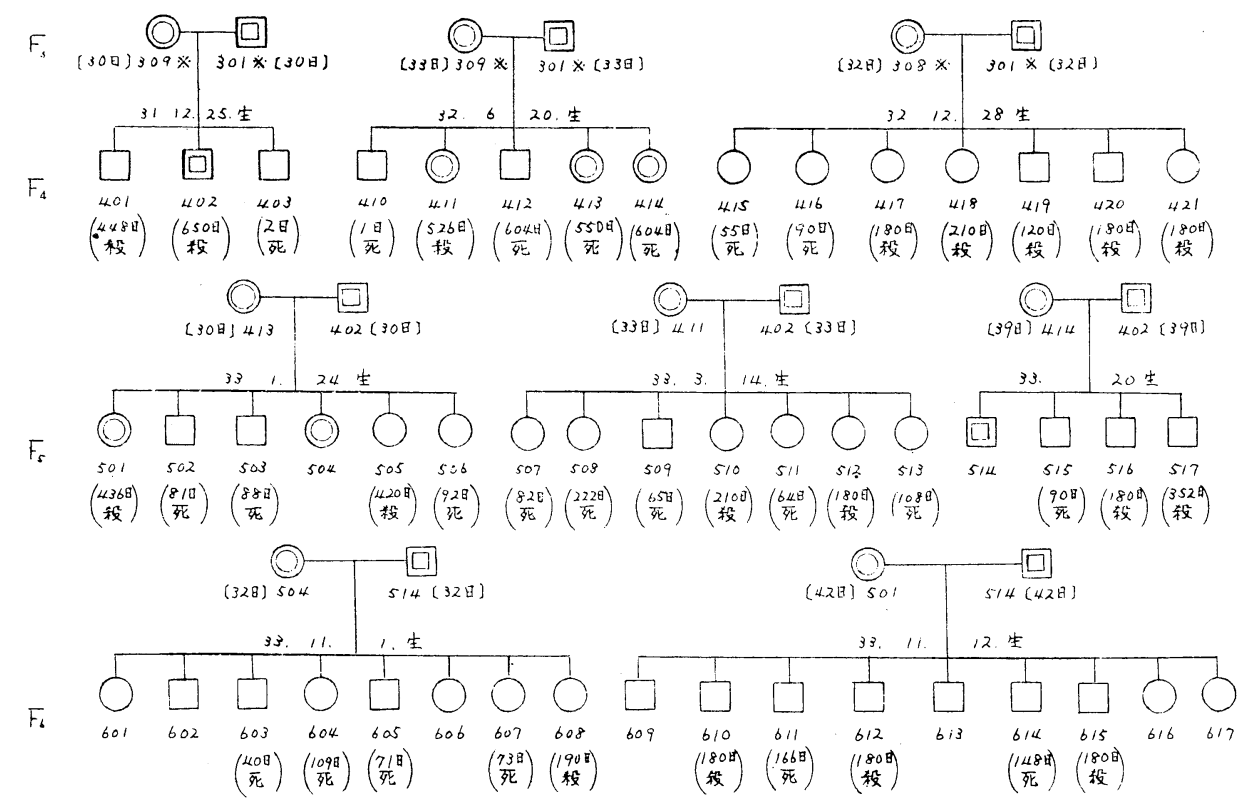

第 7 表(b) 甲末 $\mathrm{F}$ ウサギ系譜（その 2 ）

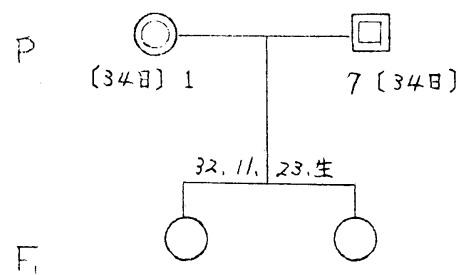

101

102

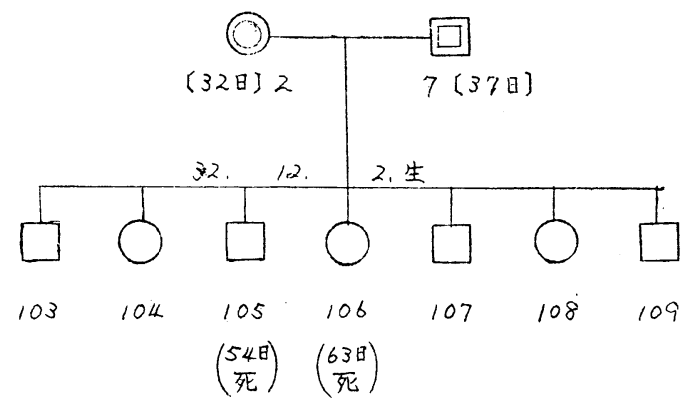

※……含持：東北医誌，㸃，357，1957を参照されたい.

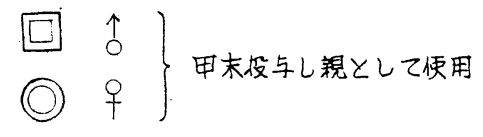

〔」内数字は交配きでの甲末投与日数 
この材料は教室の中島 ${ }^{(6)}$, 辻田 ${ }^{100)}$ ともも作製したものである.すなわち生後日数の明らかな成熟正常ウ サギの雌, 雄をとり，乙れに交配前 1 カ月またはそれ以上毎日チラジン末(帝国臟器製品) (以下甲末とする)

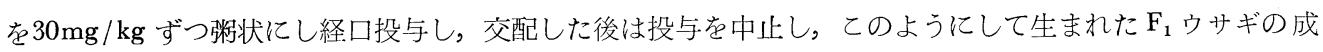
熟(大体180日以上)を待ち，上記のように同期間，同量の甲末を投与し，交配し，分婏さして仔ウサギ $\mathrm{F}_{2}$ を 得る。倉持 ${ }^{22}$ がこのような操作を 3 代くり返して得た $\mathrm{F}_{3}$ ウサギの雌 No. 308, No. 309 と雄 No. 301 を使つて 同様の操作をして $\mathrm{F}_{4}$ ウサギ21匹を得，またこの $\mathrm{F}_{4}$ ウサギの帷 No. 411，No. 413，No. 414 と雄 No. 402 とか ら同様にして $F_{5}$ ウサギ17匹を得，乙の $F_{5}$ ウサギの雌No. 501，No. 504 と雄 No. 514 とから同様操作により $\mathrm{F}_{6}$ ウサギ17匹を得た. 別に生後日数の明らかな成熟した正常ウサギの雌No. 1 ， No. 2 と雄 No. 7 とから同 様に操作して $F_{1}$ ウサギ 9 匹を得，乙れらを実験ウサギとして用いた：以上のととは第 7 表に示した通りで ある．乙れらの中，血清 PBI の測定には $\mathrm{F}_{1}$ ウサギ 7 匹， $\mathrm{F}_{4}$ ウサギ10匹， $\mathrm{F}_{5}$ ウサギ 8 匹， $\mathrm{F}_{6}$ ウサギ12匹を 使用し，血中総コレステロールの測定には $F_{1}$ ウサギ 6 匹， $F_{4}$ ウサギ 9 匹， $F_{5}$ ウサギ 7 匹， $F_{6}$ ウサギ10匹を 用い，甲状腺 $\mathrm{I}^{131}$ 揁取率の測定には $\mathrm{F}_{1}$ ウサギ 5 匹。 $\mathrm{F}_{4}$ ウサギ 6 匹， $\mathrm{F}_{5}$ ウサギ 8 匹， $\mathrm{F}_{6}$ ウサギ10匹を使用した.

(3) 甲末投与ウサギ

正常成熟ウサギに毎日甲末を $30 \mathrm{mg} / \mathrm{kg}$ ずつ約 25 日間投与した 5 匹についてそれぞれ血清 PBI，血中総コレ ステロール，甲状腺 $\mathrm{I}^{131}$ 摂取率の測定を行つた。

(4) 歴代雌，雄甲状腺摘出ウサギより生まれた子孫ウサギ(以下甲摘 $\mathrm{F}$ ウサギと称する) $\left(\mathrm{F}_{1} ， \mathrm{~F}_{4}\right.$ )

この材料は教室の辻田 ${ }^{100}$ とともに作製したものである. すなわち正常成熟ウサギの䧳，雄に甲䐱を行い， 1 力月以上過ざてから交配，分娩させて得た仔ウサギ $\left(\mathrm{F}_{1}\right)$ が成熟期に達したとき，またその雌，雄をとり同 様甲摘をし，1 カ月以上過ぎてから交配，分娩させて仔ウサギ $\left(\mathrm{F}_{2}\right)$ を得る。乙のような操作を入江 ${ }^{38)}$ が 3 代

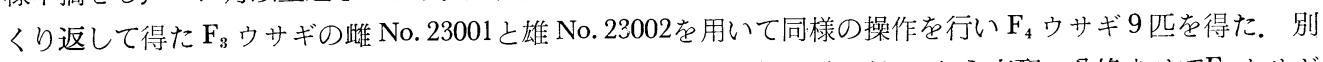
飞正常成熟ウサギの雌No. 3 と雄No. 8 をとり，甲摘後 1 力月以上経過してから交配，分娩させてF 5 匹を得た。 これらの詳細は第 8 表に示した通りであつて，血清 PBI の測定は $F_{1}$ ウギ 5 匹， $F_{4}$ ウギ 6 匹，血中総コレステロールの測定は $F_{1}$ ウサギ 5 匹， $F_{4}$ ウサギ 5 匹，明状腺 $I^{131}$ 澡取率の測定は $\mathrm{F}_{1}$ ウサギ 5 匹， $F_{4}$ ウサギ 4 匹について行つた.

第 8 表 甲摘 $\mathrm{F}$ ウサギ系蛽
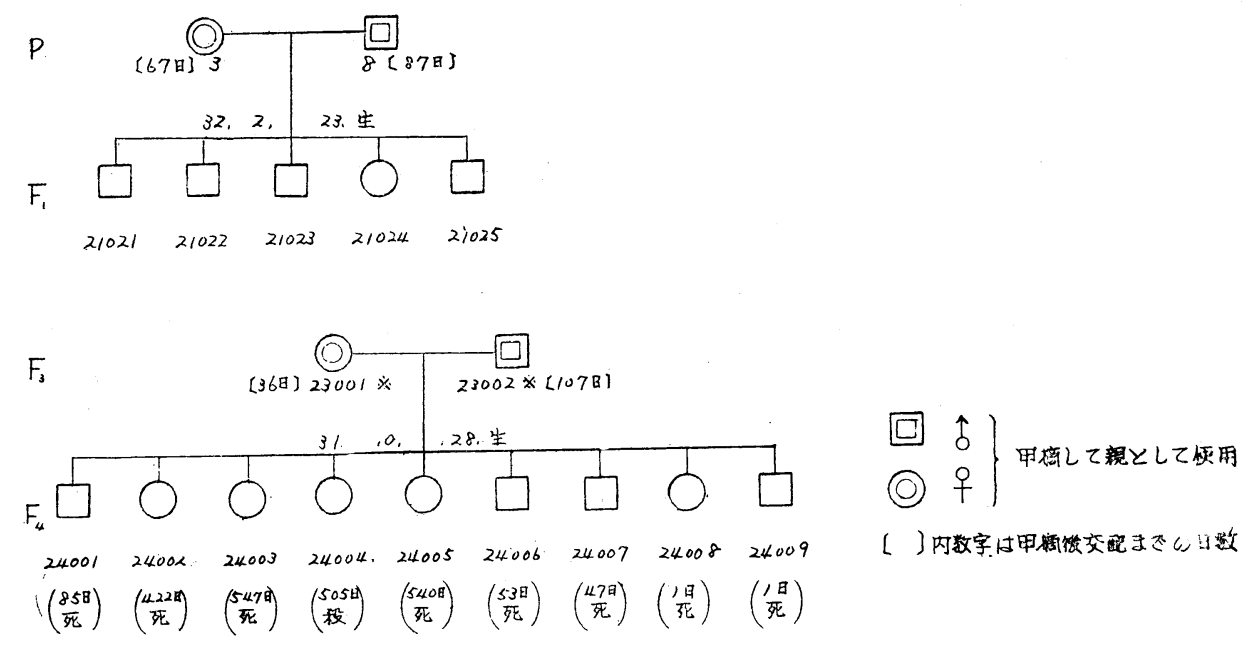

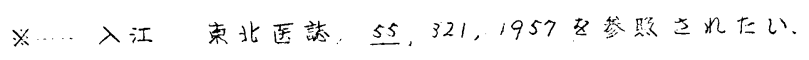


(5) 甲摘ウサギ

正常成熟ウサギの雌 3 匹，雄 2 匹について甲摘後約 25 日目に採血を行い，血清 PBI ならびに血中総コレ ステロールを測定し，次いでその中の 4 匹について甲状腺 $\mathrm{I}^{131}$ 摂取率を測定した.

\section{(b) 飼育法}

以上の実験ウサギは飼料としてオカラ，カラスムギまたはオウムギを自由に与えた. 幼少時には雑草を投 与したが，キャベッ，サッマイモッ゙ル等の甲状腺腫誘発物質を含むと考えられるものは絶対に与えないよう にした．また冬季には煖房をなし常に一定条件のもとに飼育するように留意し，仔ウサギは多く産まれた時 は，あらかじめ用意しておいたウバウサギに一部移して，生後40～50日まで親およびウバウサギとと屯に飼 育し，その後は 1 匹ずつ個々の箱に移し上記の飼料で飼育した。

\section{B 研究方法}

\section{(1) 体重測定}

実験ウサギは生後 30 日より体重測定をはじす，その後は約 1 週閒わきに測定し，ウサギの成熟するまで (ほぼ180日)観察し，正常ウサギ22匹のそれと比較した。

\section{（2）甲状腺機能検査法}

ウサギの甲状腺機能が最も旺盛になると考えられる生後150日前後 ${ }^{92)}$ を選んで採血し，血清 PBI および血 中総コレステロールの測定を行い，次いで甲状腺 $\mathrm{I}^{131}$ 掑取率を測定した. なお㭃少時死亡したウサギ中死亡 前に採血し得た 2，3のものではその血清 PBI ならびに血中総コレステロールの測定を行つた.

各測定法については第 1 篇で述べた通りである。すなわち血清 PBI 測定は血清1.0ccを用い Barker 法お よび Connor らの方法を折衷した蒸溜変法で，血中総コレステロール測定は全血 $0.2 \mathrm{cc}$ 用い Bloor 氏変法 により，甲状腺 $\mathrm{I}^{131}$ 摂取率の測定は Tracer Dosis として $\mathrm{I}^{131}$ の10 $\mu \mathrm{c}$ 使用し，Fields らの方法に準じて測 定を行つた。

\section{A 体重測定成績}

\section{III 研 究 成 績}

体重測定は生後 30 日より大体 1 週間おきに測定したのであるが，いま大体15日おきにまとめて示すと第 9 表と第10表の通りである.

第 9 表 甲末 $\mathrm{F}$ ウサギの体重測定成績（g）（その1）

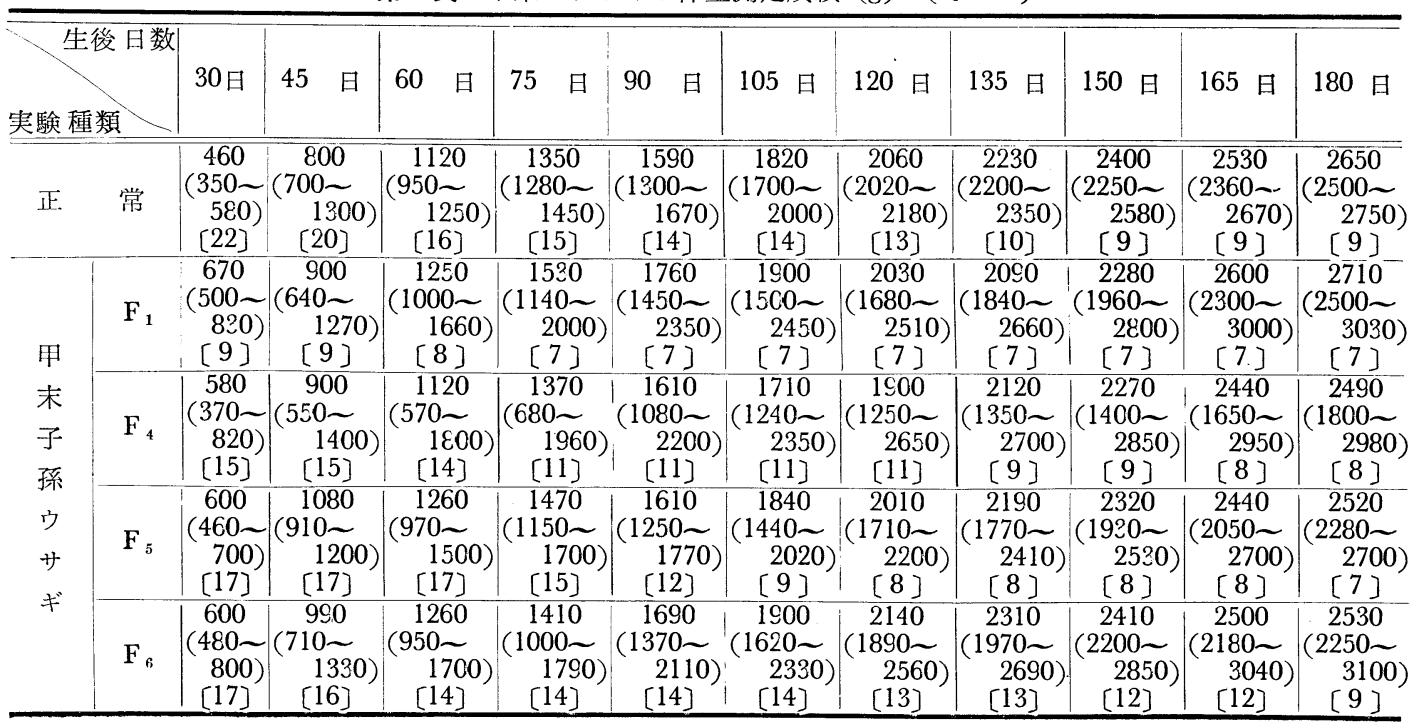

（）…体重変動範囲 [ ] …例数 


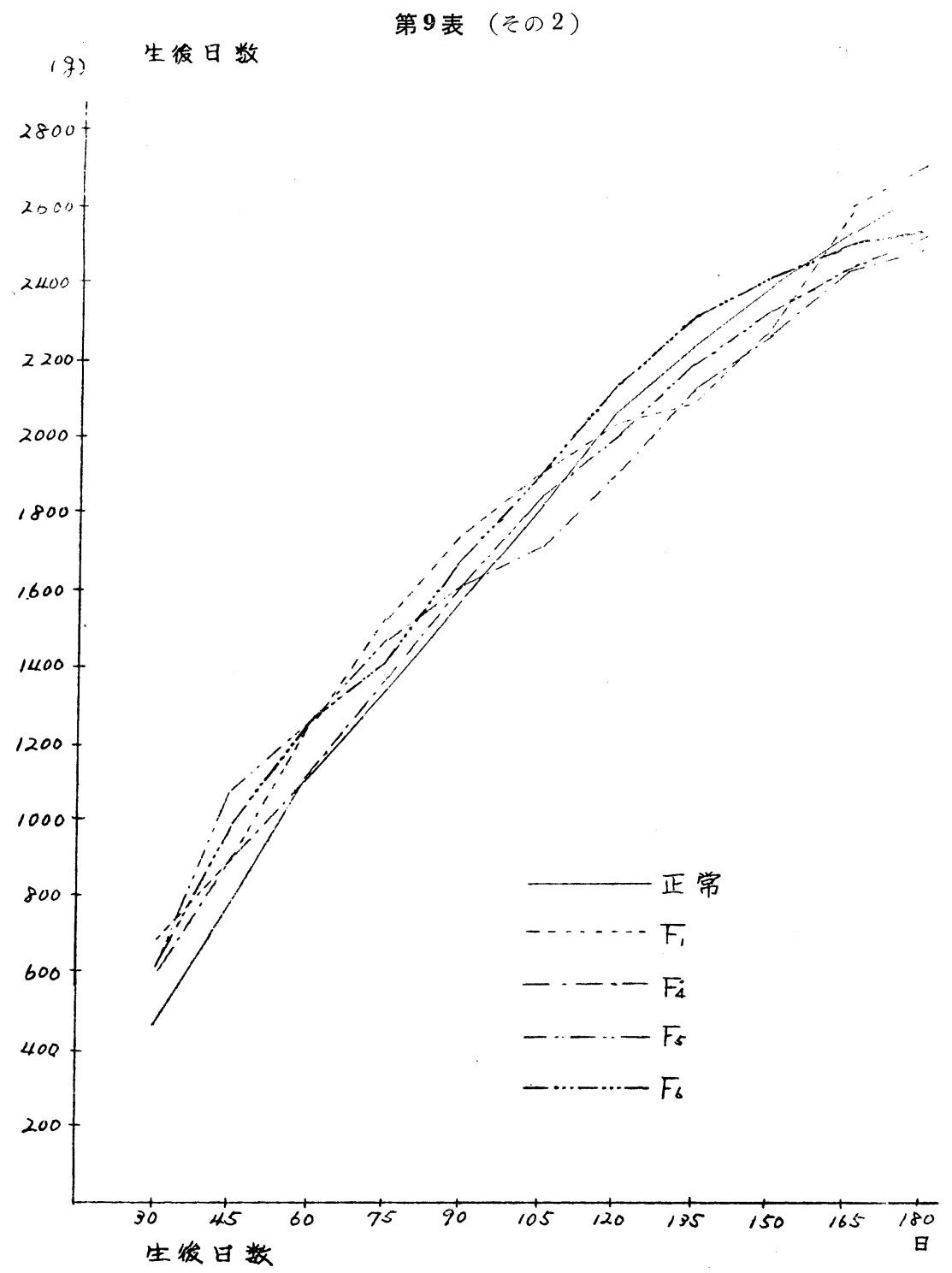

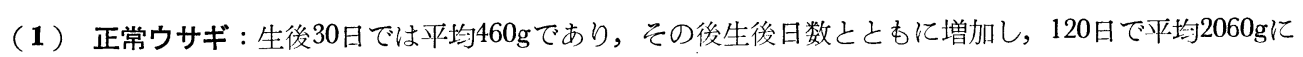
達し，180日では平均 $2650 \mathrm{~g}$ 亿つている.

(2) 甲末子孫ウサギ

第10表 甲摘 $\mathrm{F}$ ウサギの体重測定成樍（g）（その1）

\begin{tabular}{l}
\hline 生後日数 \\
実験種類
\end{tabular}



$\left(\mathrm{F}_{1}, \mathrm{~F}_{4}, \mathrm{~F}_{5}, \mathrm{~F}_{6}\right)$ の甲状腺機能について (山崎)

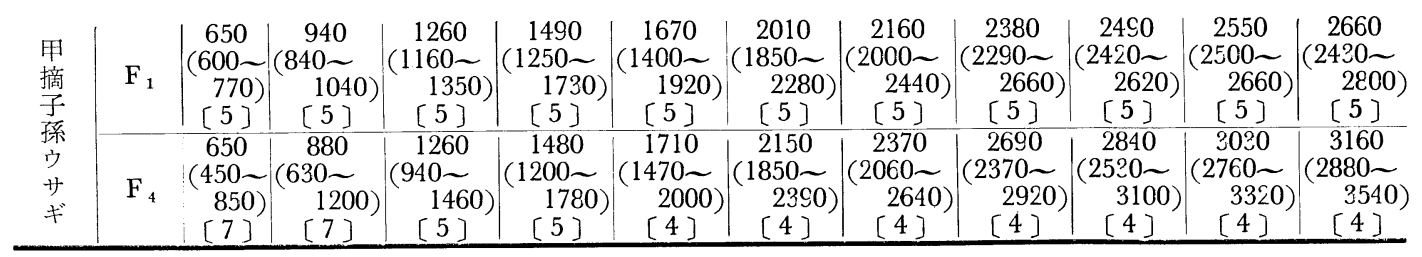

$$
\text { ( ) ) ‥体重変動範囲 [ ] …例数 }
$$

第10表（その 2 )

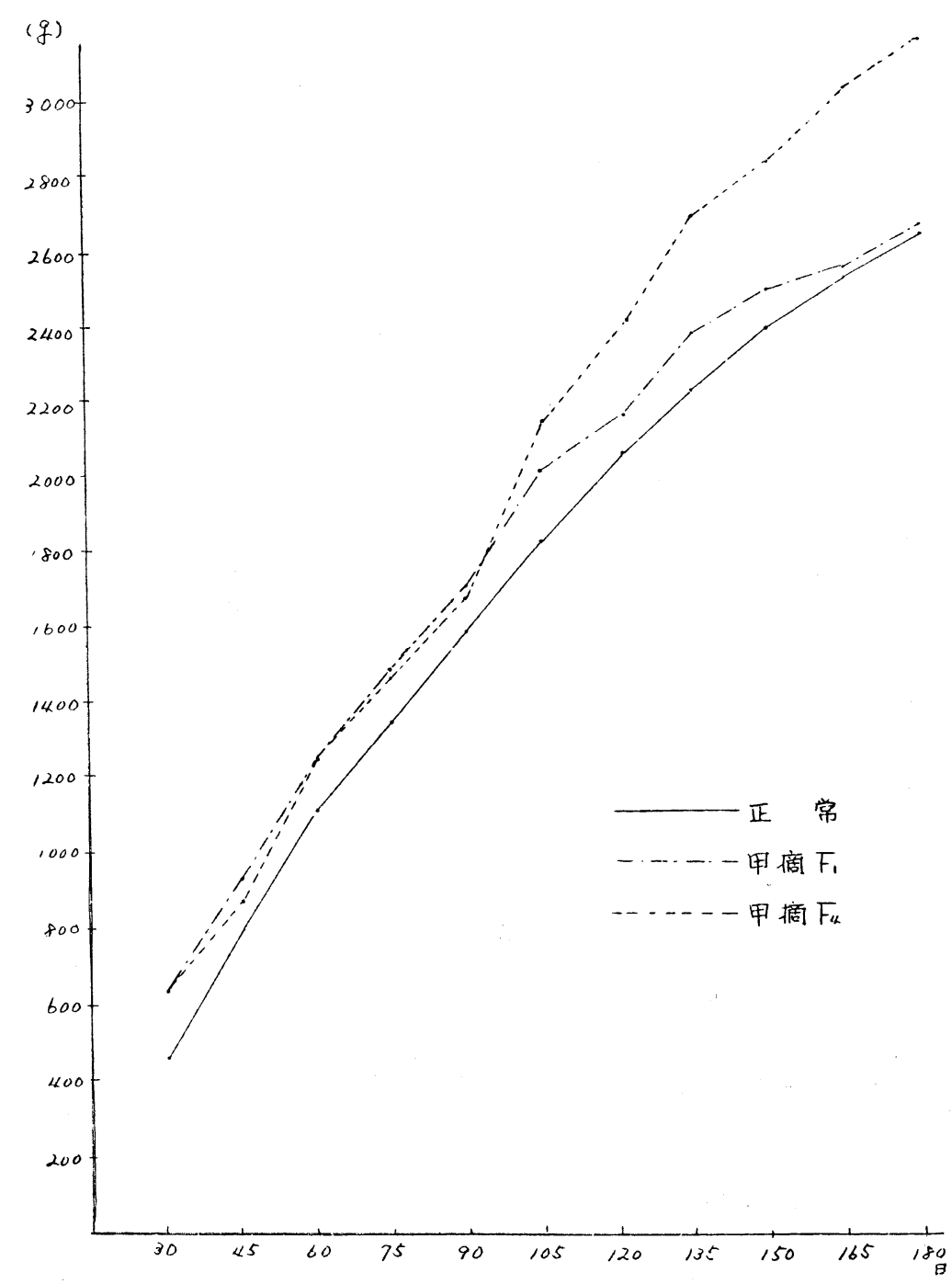

生 後日 数

(a) $\mathrm{F}_{1}$ ウサギ：生後30日では平均 $670 \mathrm{~g}$ で正常より相当大きく，そして生後 105 日頃までは正常よりやや 大きい. それ以後生後120日から150日までは正常より体重の増加率が減少し，次いで再び生後165日から正 常より大となり，180日では平均 $2710 \mathrm{~g}$ である. 
（b） $F_{4}$ ウサギ：生後30日では平均580るで，90日頃までは正常より僅かに体重の增加が大であるが，その 後は正常に比し少くなり，180日では平均 $2490 \mathrm{~g}$ である.

（c） $F_{5}$ ウサギ：生後30日では平均600gで，その後105日までは正常より成長がよく，120日以後は正常に

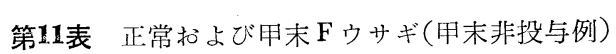
ならびに甲末投与ウサギの血清 P B I， 血中総コレステロール測定成績

\begin{tabular}{|c|c|c|c|c|c|c|}
\hline 種 & 類 & \begin{tabular}{|} 
動物 \\
番号
\end{tabular} & 性別 & $\mid$\begin{tabular}{|} 
生後 \\
日数
\end{tabular} & $\begin{array}{l}\text { P B I } \\
(\gamma / \text { dl })\end{array}$ & $\begin{array}{l}\text { 血中総コレ } \\
\text { ステール } \\
\text { 量 }(\mathrm{mg} / \mathrm{dl})\end{array}$ \\
\hline 正 & 常 & $\left|\begin{array}{l}20 \text { 例 } \\
\text { 平均 }\end{array}\right|$ & $\begin{array}{l}+10 \text { 例 } \\
\hat{\beta} 10 \text { 例 }\end{array}$ & & $\mid \begin{array}{r}4.6 \pm 0.71 \\
(3.7 \sim 6.4)\end{array}$ & $\begin{array}{l}82 \pm 14.9 \\
(59 \sim 110)\end{array}$ \\
\hline & $F_{1}$ & $\begin{array}{l}101 \\
102 \\
103 \\
104 \\
107 \\
108 \\
109\end{array}$ & $\begin{array}{l}0 \\
+ \\
+ \\
\hat{0} \\
+ \\
+ \\
\hat{\beta} \\
+ \\
\hat{0}\end{array}$ & $\begin{array}{l}144 \\
144 \\
164 \\
164 \\
164 \\
173 \\
173\end{array}$ & $\begin{array}{r}5.1 \\
6.4 \\
5.4 \\
5.2 \\
5.1 \\
4.2 \\
6.4 \\
\end{array}$ & $\begin{array}{r}97 \\
105 \\
94 \\
98 \\
\\
91 \\
83 \\
\end{array}$ \\
\hline & & 平均 & & & $5.4 \pm 0.73$ & \begin{tabular}{l|l}
3 & $95 \pm 6.8$
\end{tabular} \\
\hline $\begin{array}{l}\text { 甲 } \\
\text { 末 } \\
\text { 子 } \\
\text { 孫 }\end{array}$ & $\mathrm{F}_{4}$ & \begin{tabular}{l|}
401 \\
402 \\
406 \\
409 \\
411 \\
412 \\
413 \\
414 \\
417 \\
418
\end{tabular} & 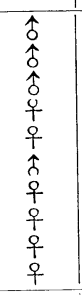 & \begin{tabular}{r|r}
168 \\
168 \\
59 \\
63 \\
145 \\
139 \\
158 \\
139 \\
180 \\
191
\end{tabular} & $\begin{array}{l}5.1 \\
9.6 \\
4.0 \\
6.4 \\
5.4 \\
9.6 \\
7.3 \\
8.4 \\
7.5 \\
8.4 \\
\end{array}$ & $\begin{array}{r}82 \\
76 \\
73 \\
88 \\
101 \\
87 \\
84 \\
86 \\
78 \\
\end{array}$ \\
\hline ウ & & 平均 & & & $7.2 \pm 1.80$ & $84 \pm 8.0$ \\
\hline $\begin{array}{l}\text { サ } \\
\text { ギ } \\
\text { 甲 } \\
\text { 末 } \\
\text { 非 } \\
\text { 投 }\end{array}$ & $\mathrm{F}_{5}$ & $\begin{array}{l}501 \\
504 \\
505 \\
508 \\
510 \\
512 \\
514 \\
517\end{array}$ & $\begin{array}{l}\text { o } \\
+ \\
+ \\
+ \\
+ \\
+ \\
+ \\
+ \\
+ \\
0 \\
0 \\
0\end{array}$ & $\begin{array}{l}164 \\
164 \\
164 \\
163 \\
162 \\
146 \\
140 \\
140 \\
\end{array}$ & $\begin{array}{l}8.4 \\
6.8 \\
7.5 \\
8.5 \\
7.8 \\
9.6 \\
9.3 \\
9.0\end{array}$ & $\begin{array}{r}102 \\
\\
125 \\
110 \\
90 \\
89 \\
74 \\
89\end{array}$ \\
\hline 尖 & & 平均 & & & $8.4 \pm 0.89$ & $97 \pm 15.5$ \\
\hline 㤎 & $\mathrm{F}_{6}$ & $\begin{array}{l}601 \\
602 \\
606 \\
608 \\
609 \\
610 \\
611 \\
612 \\
613 \\
615 \\
616 \\
617\end{array}$ & 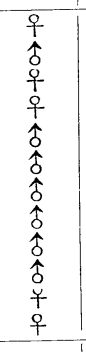 & \begin{tabular}{l|}
153 \\
153 \\
153 \\
153 \\
147 \\
147 \\
147 \\
150 \\
147 \\
150 \\
150 \\
150 \\
\end{tabular} & $\begin{array}{r}9.4 \\
10.7 \\
8.0 \\
11.3 \\
11.7 \\
8.5 \\
10.8 \\
9.6 \\
10.3 \\
9.0 \\
10.5 \\
9.8 \\
\end{array}$ & $\begin{array}{r}108 \\
124 \\
119 \\
80 \\
87 \\
94 \\
98 \\
85 \\
\\
\\
105 \\
82 \\
\end{array}$ \\
\hline & & 平均 & & & $|10.0 \pm 1.07|$ & $98 \pm 14.7$ \\
\hline \multirow[t]{2}{*}{$\begin{array}{l}\text { 甲末投 } \\
\text { ウサ }\end{array}$} & $\begin{array}{l}\text { 投与 } \\
\forall キ ゙\end{array}$ & \begin{tabular}{|r|} 
\\
7 \\
2 \\
18 \\
14 \\
\end{tabular} & 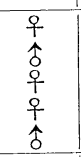 & $\begin{array}{l}200 \\
200 \\
200\end{array}$ & $\begin{array}{r}9.1 \\
9.1 \\
11.6 \\
9.8 \\
8.3\end{array}$ & $\begin{array}{l}78 \\
82 \\
57 \\
99 \\
75 \\
\end{array}$ \\
\hline & & 平均 & & & $9.6 \pm 1.11$ & $78 \pm 13.5$ \\
\hline
\end{tabular}

比し体重の増加率がやや悪く，180日では平均 $2520 \mathrm{~g}$ である.

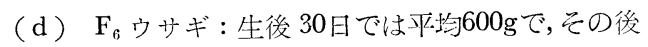
正常に比し体重の増加はやや大きく, 120 日で平均 2140gであり，165 日以後は正常より增加率は減し１80 日では平均 $2530 \mathrm{~g}$ 亿達している。

\section{(3) 甲摘子孫ウサギ}

(a) $\mathrm{F}_{1}$ ウサギ：生後 30 日では平均 $650 \mathrm{~g}$ で，その後 正常に比し体重の増加は常にやや大きく，120日では 平均 $2160 \mathrm{~g}$ 亿達し，180日では平均 $2660 \mathrm{~g}$ で正常よりに んのわずかに大である.

(b) $\mathrm{F}_{4}$ ウサギ：生後30日では平均650gで，以後常 亿正常より体重の增加率は大で, 120 日では平均 $2370 \mathrm{~g}$ に達し，180日では平均 $3160 \mathrm{~g} て ゙$ 正常よりかなり大きい．

\section{B 血清 PBI 測定成績}

\section{(1) 正常ウサギの血清 PBI 值}

雌10匹，雄10匹の合計20匹について測定した值は第

1 篇第 4 表に示した。すすなわち鹳10匹の平均值は 4.7

第6図 血清PBI測定成䋶

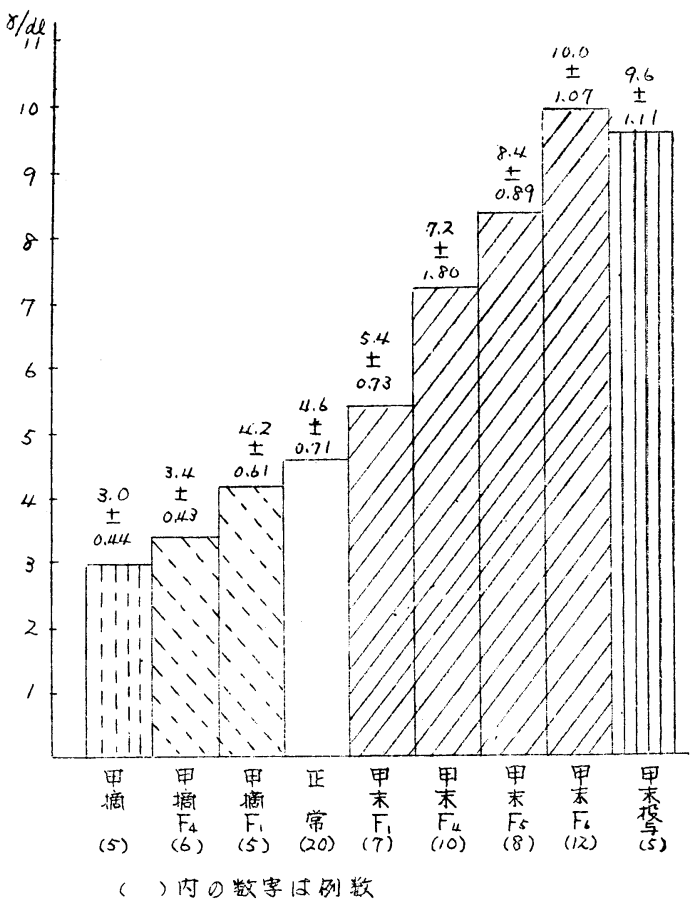


$r / \mathrm{dl}$ で，雄10匹の平均值は4.5 $/ \mathrm{dl}$ であり，両性間には有意の差はない，合計 20匹では 3.7 6.4 $\gamma / \mathrm{dl}$ の範囲 飞分布し，平均值 $4.6 \pm 0.71 \gamma / \mathrm{d} 1$ である.

（2）甲末子孫ウサギ $\left(F_{1} ， F_{4} ， F_{5} ， F_{6}\right)$ の血清 $\mathrm{PBI}$ 測定值（第11表及び第6 図参照）

（a）甲末 $F_{1}$ ウサギの血清 PBI 值 : 雌 4 匹，雄 3 匹の合計 7 匹について測定した。雌 4 匹平均值は5.3r/

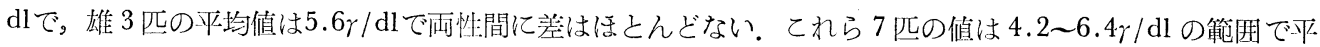
均 $5.4 \pm 0.73 \gamma / \mathrm{dl}$ であつて，正常に比しやや高值を示している.

（b）甲末 $\mathrm{F}_{4}$ ウサギの血清 PBI 值：倠 6 匹の平均值は $7.2 \gamma / \mathrm{dl}$ で，雄 4 匹の平均值は $7.1 \gamma / \mathrm{dl}$ であり，全 10匹では4.0 9.6\%/dlの範囲に分布し，平均值は $7.2 \pm 1.80 \gamma / \mathrm{d} 1$ であつて，正常平均值の 1.5 倍以上を示して いる。

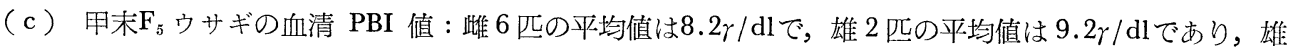
の方が踓に比しやや高值を示している. 全 8 匹の測定值は6.8 9.6r/d1の範囲で，平均 $8.4 \pm 0.89 \gamma / \mathrm{dl}$ であ り，正常平均值の約1.8倍に達している.

（d）甲末 $\mathrm{F}_{6}$ ウサギの血清 $\mathrm{PBI}$ 值 : 雌 5 匹の平均值は $9.8 \mathrm{r} / \mathrm{dl}$ で, 雄 7 匹の平均值は $10.1 \mathrm{r} / \mathrm{dl}$ で, 全 12 匹 の測定值は8.0〜 11.7 $/ \mathrm{d} 1$ の範团に分布し，平均 $10.0 \pm 1.07 \gamma / \mathrm{d} 1$ で正常平均值の約 2.1 倍にも達している.

（3）甲末投与ウサギの血清 PBI 值 : 雌 3 匹，雄 2 匹の合計 5 匹について測定を行つた（第11表，第 6 図 参照). 雌 3 匹の平均值は $10.3 \gamma / \mathrm{dl}$ で, 雄 2 匹の平均値は8.7 $/ \mathrm{dl}$ であり, 雌の方が雄よりかなり高值を示し ている. 全 5 匹の測定では8.3 11.6r/dlの範囲で，平均 $9.6 \pm 1.11 \gamma / \mathrm{dl}$ である.

以上の血清 PBI 值につき統計学的にその有意性を $t=\frac{M_{1}-M_{2}}{\sqrt{n_{1} S_{1}{ }^{2}+n_{2} \bar{S}_{2}{ }^{2}}} \sqrt{\frac{n_{1} n_{2}\left(n_{1}+n_{2}-2\right)}{n_{1}+n_{2}}}\left(M_{1} M_{2}\right.$ は算術

第12表 正常打よび甲末 $\mathrm{F}$ ウサギ (甲末非投与例)の P B I 計测 值に打ける統計学的観察

（有意水準 $1 \%$ )

\begin{tabular}{|c|c|c|c|c|c|}
\hline & 正常 & $\mathrm{F}_{1}$ & $\mathrm{~F}_{4}$ & $\mathrm{~F}_{5}$ & $F_{6}$ \\
\hline 正常 & & 2.4 & 5.4 & 11.5 & 16.6 \\
\hline $\mathrm{F}_{1}$ & - & & 2.3 & 6.6 & 9.5 \\
\hline $\mathrm{F}_{4}$ & + & - & & 1.6 & 4.3 \\
\hline $\mathrm{F}_{5}$ & + & + & - & & 3.3 \\
\hline $\mathrm{F}_{6}$ & + & + & + & + & \\
\hline $\begin{array}{r}\mathrm{M}_{1}, \\
\mathrm{n}_{1} \mathrm{~S}\end{array}$ & $\begin{array}{l}\frac{\mathrm{M}_{1}-}{\mathrm{n}_{1} \mathrm{~S}_{1}^{2}+} \\
\Lambda_{2} \cdots \text { 算 } \\
{ }^{2}, \mathrm{n}_{2} \mathrm{~S}\end{array}$ & $\begin{array}{l}{\left[_{2}\right.} \\
\mathrm{I}_{2} \mathrm{~S}_{2}{ }^{2} \\
\text { 平均 } \\
\cdots \text { 偏 }\end{array}$ & $\mathrm{n}_{1} \mathrm{n}_{2}(\mathrm{r}$ & $\begin{array}{l}\frac{1+\mathrm{n}_{2}-}{+\mathrm{n}_{2}} \\
\text {-例数, }\end{array}$ & \\
\hline
\end{tabular}

平均值; $\mathrm{n}_{1}, \mathrm{n}_{2}$ は例数; $\mathrm{n}_{1} \mathrm{~S}_{1}{ }^{2}, \mathrm{n}_{2} \mathrm{~S}_{2}{ }^{2}$ は偏差平方和）の式を用 いてしらべたところ(第12表参照)，正常と $\mathrm{F}_{4}, \mathrm{~F}_{5}, \mathrm{~F}_{6}$ ウサギ 間および $\mathrm{F}_{1}$ と $\mathrm{F}_{5} ， \mathrm{~F}_{6}$ 間， $\mathrm{F}_{1} \sim \mathrm{F}_{6}$ 間， $\mathrm{F}_{5} \sim \mathrm{F}_{6}$ 間に $1 \%$ の有意 水準で高度に有意性がみとめられたが，正常と $\mathrm{F}_{1} お よ ひ ゙ F_{1}$ $\mathrm{F}_{4}$ 間， $\mathrm{F}_{4} \sim \mathrm{F}_{5}$ 間には有意の差はみられなかつた。 な打各代と あ雌，雄両性間の PBI 值の差は小さく，有意の养はみられ なかつた。

以上のように $\mathrm{F}_{1}, \mathrm{~F}_{4}, \mathrm{~F}_{5}, \mathrm{~F}_{6}$ と代を重ねるに従つてその血 清 PBI 值は階段的に高值を示し， $F_{6}$ ウサギでは遂に甲末投 与ウサギの PBI 值を越え正常平均值の約 2.1 倍に達している. これは教室の中島 ${ }^{66)}$ が同一の材料を使つて観察した組織学的 および組織計測学的所見とよく一致するものである。

(4) 甲摘子孫ウサギ $\left(F_{1}, F_{4}\right)$ の血清 PBI 值 (第13表第 6 図 参照)

（a）甲摘 $\mathrm{F}_{1}$ ウサギの血清 PBI 值: 雌 1 匹，雄 4 匹の合 棓 5 匹について測定した. 3.4〜 5.2 $\gamma / \mathrm{dl}$ の範囲で。平均 4.2 $\pm 0.61 \gamma / \mathrm{dl}$ であり，正常平均值に比しわずかに低值を示して

いる.

(b) 甲摘 $\mathrm{F}_{4}$ ウサギの血清 PBI 值 : 雌 4 匹，雄 2 匹の合計 6 匹について測定した. 2.9 4.1 $/ \mathrm{dl}$ の範讲 に分布し平均 $3.4 \pm 0.43 \gamma / \mathrm{dl}$ で $\mathrm{F}_{1}$ および正常平均值よりさらに低值を示している。

（5）甲摘ウサギの血清 PBI 值 : 雌 3 匹，雄 2 匹の合計 5 匹ににつて測定し，2.7〜 3.9r/dl の範囲に 分 布，平均值 $3.0 \pm 0.44 \mathrm{r} / \mathrm{dl}$ を得た(第 13 表，第 6 図参照).

以上のように $\mathrm{F}_{1} ， \mathrm{~F}_{4}$ と代が進むに従い累代性に低值を示し，次第に甲摘ウサギの PBI 值に近づいている。 C 血中総コレステロール測定成績 
（1）正常ウサギの血中総コレステロール値：雌10匹，雄10匹の合計20匹について測定した値は第 1 篇第 4 表に示した. 59〜 $110 \mathrm{mg} / \mathrm{dl}$ の範囲に分布し，平均 $82 \pm 14.9 \mathrm{mg} / \mathrm{dl}$ を示し各測定值の間に相当门のある值 を得た。

（2）甲末子孫ウサギ( $\left.F_{1} ， F_{4}, F_{5} ， F_{6}\right)$ の血中総コレステロール值（第11表，第 7 図参照）

(a) 甲末 $F_{1}$ ウサギの血中総コレスデロール值 : 雌 4 匹，雄 2 匹の合計 6 匹について測定を行つた. 83〜 $105 \mathrm{mg} / \mathrm{dl}$ の範囲で平均 $95 \pm 6.8 \mathrm{mg} / \mathrm{dl}$ であり, 正常平均值より僅かに高い值を示している.

(b) 甲末 $F_{4}$ ウサギの血中総コレステロール值 : 雌 5 匹，雄 4 匹合計 9 匹について測定したととろ。73〜 $101 \mathrm{mg} / \mathrm{dl}$ の範囲に分布し平均 $84 \pm 8.0 \mathrm{mg} / \mathrm{dl}$ で正常平均值より僅か傐值を示している.

(c) 甲末 $F_{5}$ ウサギの血中総コレステロール值 : 雌 5 匹，雄 2 匹の合計 7 匹 について測定した. $74 〜 125$ $\mathrm{mg} / \mathrm{dl}$ の範囲で, 平均值 $97 \pm 15.5 \mathrm{mg} / \mathrm{dl}$ で正常平均值より高い.

(d) 甲末 $F_{6}$ ウサギの血中総コレスデロール值 : 雌, 雄各 5 匹の合計10匹について測定した. 80〜 $124 \mathrm{mg}$ $/ \mathrm{dl}$ の範囲に分布し，平均值は $98 \pm 14.7 \mathrm{mg} / \mathrm{dl}$ で正常平均值より高い值を示している.

以上のように甲末 $\mathrm{F}$ ウキギの血中総コレステロール值はほとんど大部分正常值の範囲内にあり，各代の平 均值はいずれあ正常平均值より僅かに高い值を示している.

（3）甲末投与ウサギの血中総コレステロール值（第11表，第 7 図参照）

雌 3 匹，雄 2 匹の合計 5 匹について測定したところ，57〜 99 $\mathrm{mg} / \mathrm{dl}$ の範囲にあり，1 例を除いて全部正常 範囲内に分布しているが，平均值は $78 \pm 13.5 \mathrm{mg} / \mathrm{dl}$ で正常平均值よりやや低值を示している.

（4）甲摘子孫ウサギ $\left(F_{1} ， F_{4}\right)$ の血中総コレステロール值（第13表，第 7 図参照）

第13表 正常扎よび甲摘 $\mathrm{F}$ ウサギ（非甲摘例） ならびに甲摘ウサギの血清 P B I， 血中総コレステロール測定成縝

\begin{tabular}{|c|c|c|c|c|c|}
\hline 種類 & $\begin{array}{l}\text { 動物 } \\
\text { 番号 }\end{array}$ & 性别 & \begin{tabular}{|l|} 
生後 \\
日数
\end{tabular} & $\begin{array}{l}\text { P B I } \\
(\gamma / \mathrm{dl})\end{array}$ & $\begin{array}{l}\text { 血中総コレ } \\
\text { スデール } \\
(\mathrm{mg} / \mathrm{dl})\end{array}$ \\
\hline 正常 & & $\begin{array}{l}+10 \text { 例 } \\
\text { 今 } 10 \text { 例 }\end{array}$ & & $\begin{array}{r}4.6 \pm 0.71 \\
(3.7 \sim 6.4)\end{array}$ & $\begin{array}{c}82 \pm 14.9 \\
(59 \sim 110)\end{array}$ \\
\hline \multirow{2}{*}{\begin{tabular}{l|l} 
甲 & \\
摘 & \\
\\
孫 \\
ウ
\end{tabular}} & $\begin{array}{l}21021 \\
21022 \\
21023 \\
21024 \\
21025\end{array}$ & 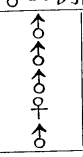 & $\begin{array}{l}200 \\
163 \\
200 \\
163 \\
200 \\
\end{array}$ & \begin{tabular}{|l|}
4.4 \\
5.2 \\
3.8 \\
3.4 \\
4.2 \\
\end{tabular} & $\begin{array}{r}116 \\
78 \\
90 \\
102 \\
86 \\
\end{array}$ \\
\hline & 平均 & & & $4.2 \pm 0.61$ & $95 \pm 13.3$ \\
\hline \multirow[t]{2}{*}{ 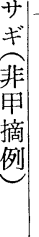 } & $\begin{array}{l}24001 \\
24002 \\
24003 \\
24004 \\
24005 \\
24006\end{array}$ & 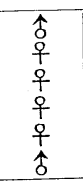 & $\begin{array}{r}85 \\
205 \\
138 \\
141 \\
205 \\
53 \\
\end{array}$ & $\begin{array}{l}4.1 \\
3.2 \\
3.7 \\
2.9 \\
3.7 \\
3.0 \\
\end{array}$ & $\begin{array}{r}205 \\
82 \\
128 \\
89 \\
109\end{array}$ \\
\hline & 平均 & & & $3.4 \pm 0.43$ & $123 \pm 44.2$ \\
\hline \multirow[t]{2}{*}{\begin{tabular}{l} 
甲 \\
摘 \\
ウ \\
サ \\
\multirow{2}{*}{}
\end{tabular}} & $\begin{array}{r}3 \\
4 \\
8 \\
16 \\
19 \\
\end{array}$ & $\begin{array}{l}\text { 우 } \\
\text { + } \\
\text { 京 } \\
\text { 全 } \\
\text { + }\end{array}$ & $\begin{array}{l}210 \\
220 \\
210\end{array}$ & $\begin{array}{l}2.8 \\
3.9 \\
2.9 \\
2.7 \\
2.9 \\
\end{array}$ & $\begin{array}{r}102 \\
133 \\
78 \\
95 \\
180 \\
\end{array}$ \\
\hline & 平均 & & & $3.0 \pm 0.44$ & $118 \pm 35.9$ \\
\hline
\end{tabular}

第 7 図 血中総コレステロール測定成續

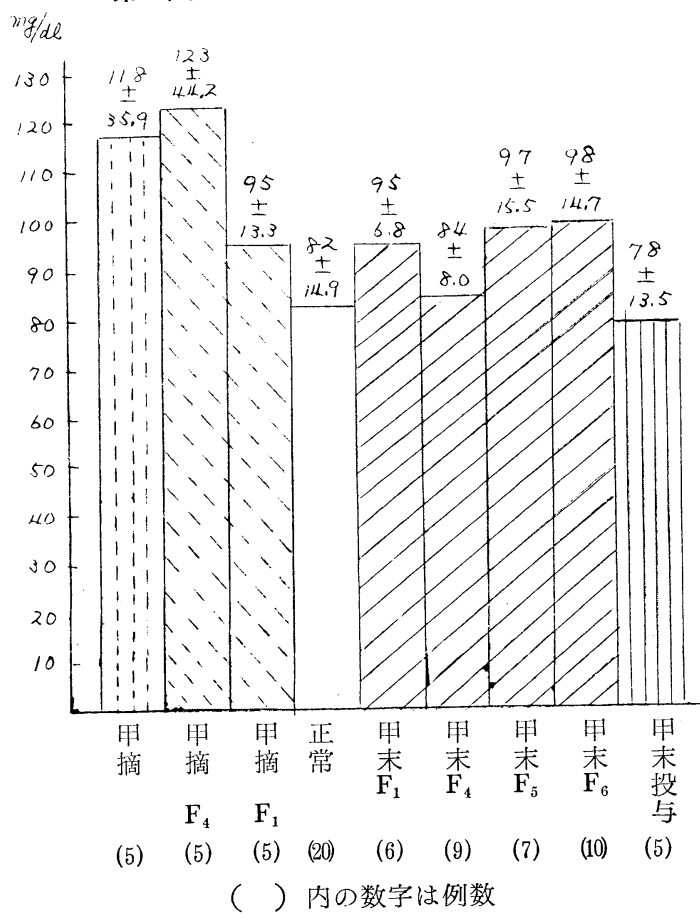

(a) 甲摘 $\mathrm{F}_{1}$ ウサギの血中総コレステロール值 : 雌 1 匹，雄 4 匹の合計 5 匹について測定した，78〜116 $\mathrm{mg} / \mathrm{dl}$ の範囲で，平均95 $13.3 \mathrm{mg} / \mathrm{dl}$ であり，正常平均值より高い做な示している.

(b) 甲摘 $\mathrm{F}_{4}$ ウサギの血中総コレスアロール值 : 雌 4 匹，雄 1 匹の 5 匹について 測定したところ，82〜 
$205 \mathrm{mg} / \mathrm{dl}$ の範囲に分布し，平均值は $123 \pm 44.2 \mathrm{mg} / \mathrm{dl}$ で，正常平均值に比しかなり高值を示している.

（5）甲摘ウサギの血中総コレステロール值（第13表，第 7 図参照）

雌 3 匹，雄 2 匹の合計 5 匹について測定し78〜 $180 \mathrm{mg} / \mathrm{dl}$ の範囲の值を得，平均值は $118 \pm 35.9 \mathrm{mg} / \mathrm{dl}$ で, 正常平均值よりかなり高い值を得た。

以上のように甲摘 $\mathrm{F}$ ウサギの血中総コレステロール值は各代とも測定値間に相当巾のある值を示すが，こ の平均值はいずれ屯正常平均值より高くかつ経代的に高值を示し，さらにF、ウサギでは甲摘ウサギの值を 越えている。

D 甲状腺 $\mathbf{I}^{131}$ 摂取率測定成績

第14表 正常扎よび甲末 $\mathrm{F}$ ウザ(甲末非投与例)ならびに 甲末投与ウサギの甲状腺 $\mathrm{I}^{131}$ 摂取率測定成績(\%)

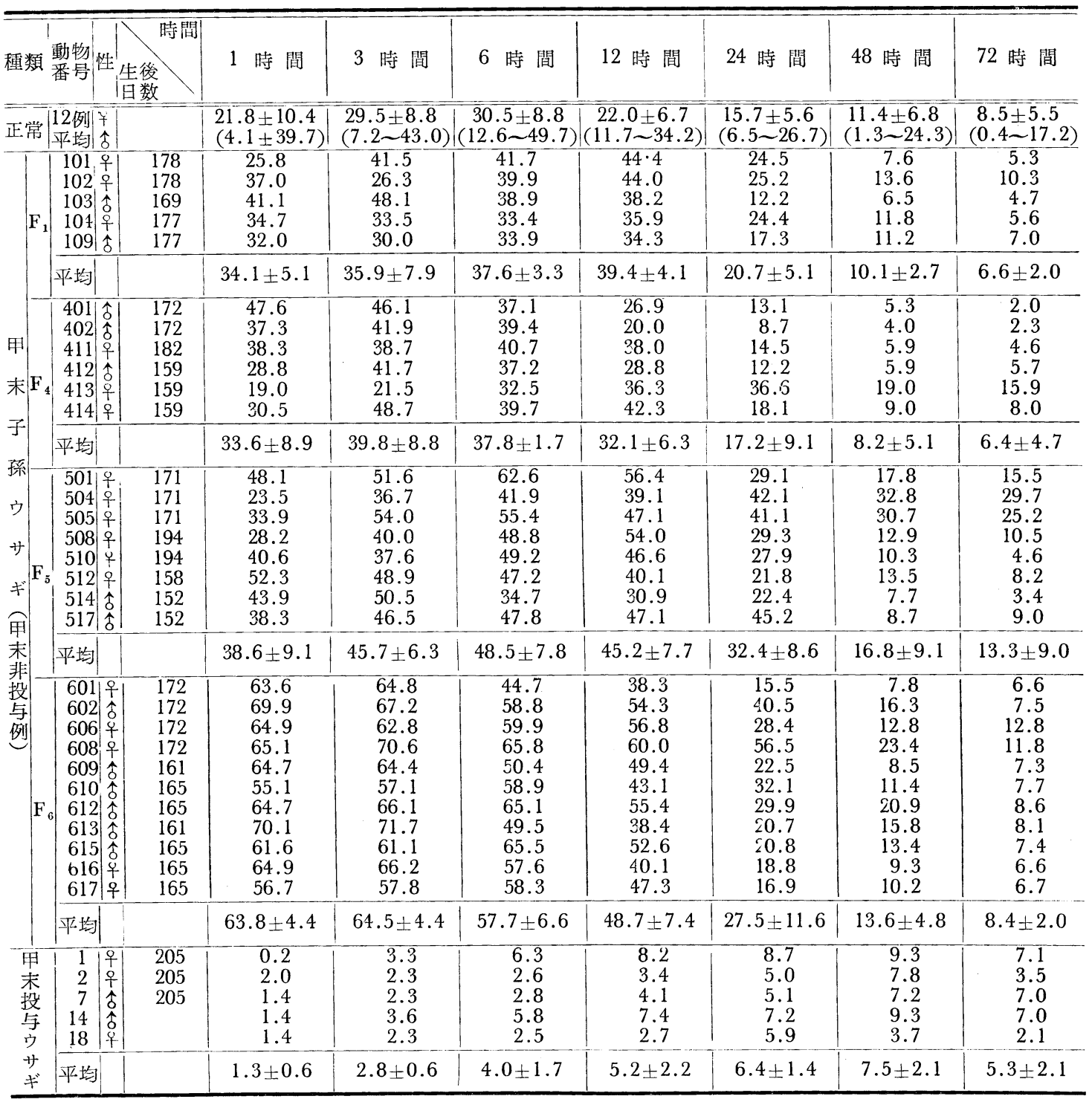


第 8 図＼cjkstart正常扔よび甲末 $\mathrm{F}$ ウザ(甲末非投与例)ならびに甲末投与ウサギの

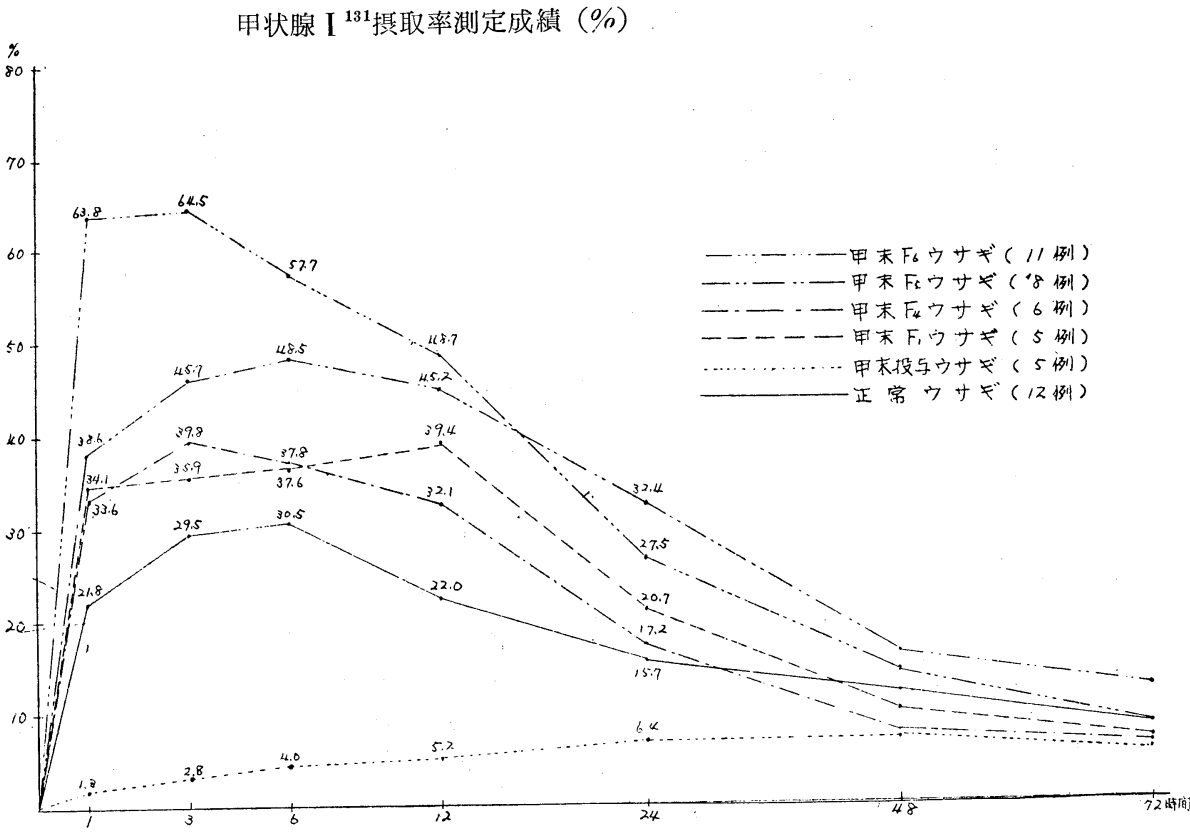

（1）正常ウサギの甲状腺 $\mathbf{1}^{131}$ 摂取率測定值：正常ウサギ12匹の成績は第 1 篇に述へた通りである. その 平均值は， $\mathrm{NaI}^{131}$ 注射後 1 時間值 : $21.8 \pm 10.4 \%$ でその後次第に増加し 3 時間值 : $29.5 \pm 8.8 \%, 6$ 時間值： $30.5 \pm 8.8 \%$ で最高值を示し，次いで12時間值 : $22.0 \pm 6.7 \% ， 24$ 時間值 : $15.7 \pm 5.6 \% ， 48$ 時間值: $11.4 \pm$ $6.8 \%$ とぜんじ減少し72時間值は $8.5 \pm 5.5 \%$ である. 雌 6 匹の平均值は雄 6 匹の平均值より注射後 24 時間值 までは高值を示し，その後は雄より低值である。

(2) 甲末子孫ウサギ $\left(F_{1}, F_{4}, F_{5}, F_{6}\right)$ の甲状腺 $\mathbf{1}^{131}$ 摂取率測定値（第14表，第 8 図参照)

(a) 甲末 $\mathrm{F}_{1}$ ウサギ： 5 匹平均值は $\mathrm{NaI}^{131}$ 注射後 1 時間值 : $34.1 \pm 5.1 \% ， 3$ 時間值 : $35.9 \pm 7.9 \% ， 6$ 時間值 : $37.6 \pm 3.3 \%$ とぜんじ高值を示し，12時間値 : $39.4 \pm 4.1 \%$ で最高值を示しその後 24 時間値 : $20.7 \pm$

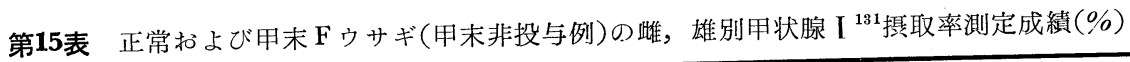

\begin{tabular}{|c|c|c|c|c|c|c|c|c|c|c|}
\hline 種 & 類 & 性 別 & 例数 間 & 1 時間 & 3 時間 & 6 時間 & 12 時間 & 24 時間 & 48時間 & 72時間 \\
\hline \multirow{2}{*}{ 正 } & \multirow{2}{*}{ 常 } & 雌平均 & 6 & 23.7 & 32.7 & 35.3 & 24.4 & 16.3 & 9.5 & 7.2 \\
\hline & & 雄平均 & 6 & 19.9 & 26.2 & 25.7 & 19.6 & 15.2 & 13.3 & 9.9 \\
\hline \multirow{8}{*}{ 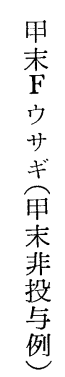 } & \multirow{2}{*}{$\mathrm{F}_{1}$} & 雌平均 & 2 & 32.5 & 33.8 & 38.3 & 41.4 & 24.7 & 11.0 & 7.1 \\
\hline & & 雄平均 & 3 & 36.6 & 39.1 & 36.4 & 36.3 & 14.8 & 8.9 & 5.9 \\
\hline & \multirow{2}{*}{$\mathrm{F}_{4}$} & 雌平均 & 3 & 29.3 & 36.3 & 37.6 & 38.9 & 23.1 & 11.3 & 9.5 \\
\hline & & 雄平均 & 3 & 37.9 & 43.2 & 37.9 & 25.2 & 11.3 & 5.1 & 3.3 \\
\hline & \multirow{2}{*}{$\mathrm{F}_{5}$} & 雌平均 & 6 & 37.8 & 44.8 & 50.9 & 47.2 & 31.9 & 19.7 & 15.6 \\
\hline & & 雄平均 & 2 & 41.1 & 48.5 & 41.3 & 39.0 & 33.8 & 8.2 & 6.2 \\
\hline & \multirow{2}{*}{$\mathrm{F}_{6}$} & 雌平均 & 5 & 63.0 & 64.4 & 57.3 & 48.5 & 27.2 & 12.7 & 8.9 \\
\hline & & 雄平均 & 6 & 64.4 & 64.6 & 58.0 & 47.2 & 27.8 & 14.4 & 7.8 \\
\hline
\end{tabular}


$5.1 \%$ といずれも正常平均值より高く。次いで48時間值：10.1 $2.7 \% ， 72$ 時間值 : $6.6 \pm 2.0 \%$ と正常より低 值を示している. 雌 2 匹の平均值は雄 3 匹の平均值に比し 3 時間值までは低いが 6 時間值以後はいずれす雄 より高值を示している（第15表参照）.

(b) 甲末 $\mathrm{F}_{4}$ ウサギ：6 匹平均值は $\mathrm{NaI}^{131}$ 注射後 1 時間值 : $33.6 \pm 8.9 \%$ で正常值より高いが，甲末 $\mathrm{F}_{1}$ ウサギよりわずかと低く，3時間值：39.8 $8.8 \%$ で最高值を示し，6時間值 $: 37.8 \pm 1.7 \%$ と $F_{1}$ ウサギよ り高く，次いで12時間值 : $32.1 \pm 6.3 \% ， 24$ 時間值 : $17.2 \pm 9.1 \%$ と $F_{1}$ ウサギに比し低值であるが，いずれ あ正常值より高值を示し，その後48時間值 : $8.2 \pm 5.1 \% ， 72$ 時間值 : $6.4 \pm 4.7 \%$ と正常より低い值を示して いる. 雌 3 匹平均值は雄 3 匹の平均值に比して 6 時間值までは低いが，12時間值以後はいずれも雄より高値 を示している (第15表参照).

(c) 甲末 $\mathrm{F}_{5}$ ウサギ： 8 匹平均値は $\mathrm{NaI}^{131}$ 注射後 1 時間值 : $38.6 \pm 9.1 \%$ でその 後ぜんじ高くなり 3 時 間值 : $45.7 \pm 6.3 \% ， 6$ 時間值 : $48.5 \pm 7.8 \%$ で最高值を示し，次いで12時間值 : $45.2 \pm 7.7 \% ， 24$ 時間值 :

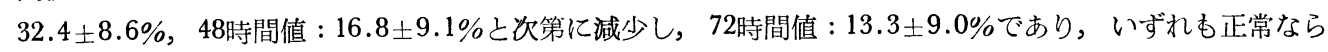
びに $F_{1}, F_{4}$ サギの各值より高い值を示している. 雌 6 匹の平均值は雄 2 匹の平均值に比し 1,3 および 24 時間值は低いが他の值はいずれも雄より高值を示している(第15表参照).

(d) 甲末 $\mathrm{F}_{6}$ ウサギ：11匹の平均值は $\mathrm{NaI}^{131}$ 注射後 1 時間值 : $63.8 \pm 4.4 \%$ と非常に高値を示し， 3 時間

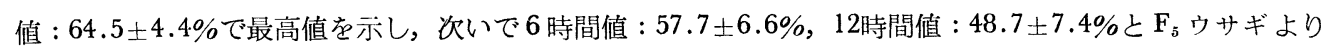
さらに高い値を示しているが，その後24時間值： $27.5 \pm 11.6 \% ， 48$ 時間值： $13.6 \pm 4.8 \%$ と $\mathrm{F}_{5}$ ウサギより低 くなり，72時間值 : $8.4 \pm 2.0 \%$ で $F_{5}$ および正常ウサギより低值を示している. 雌 5 匹の平均值は雄 6 匹の 平均值に比して12および72時間值以外はいずれも低值である(第15表参照).

（3）甲状投与ウサギの甲状腺 ${ }^{13}$ 摂取率測定值（第 14 表，第 8 図参照）

5 匹平均值は $\mathrm{NaI}^{131}$ 注射後 1 時間值 : $1.3 \pm 0.6 \%$ でその後次第に 增加し， 3 時間値 : $2.8 \pm 0.6 \% ， 6$ 時

第16表 正常扔よび甲末 $\mathrm{F}$ ウサギ(甲未非投与例)の甲状腺 $\mathrm{I}^{131}$ 摂取率測定值に扣ける統計学的篗察 有意水準 $1 \%$

1 時間值

\begin{tabular}{|c|c|c|c|c|c|}
\hline & 正常 & $\mathrm{F}_{1}$ & $\mathrm{~F}_{4}$ & $F_{5}$ & ${ }_{6}$ \\
\hline 正常 & & 2.3 & 2.2 & 3.5 & $\mid 11.6$ \\
\hline$F_{1}$ & - & & 0.1 & 0.9 & 11.0 \\
\hline $\mathrm{F}_{4}$ & - & - & 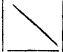 & 0.9 & 8.7 \\
\hline $\mathrm{F}_{\mathrm{j}}$ & + & - & - & & 6 \\
\hline $\mathrm{F}_{6}$ & + & + & + & + & \\
\hline \multicolumn{6}{|c|}{ 12時間値 } \\
\hline & |正常| & $F_{1}$ & $F_{4}$ & $F_{5}$ & $F_{6}$ \\
\hline 正常 & 5 & 4.9 & 2.8 & 6.6 & 8.5 \\
\hline$F_{1}$ & + & & 2.0 & 1.4 & 2.4 \\
\hline $\mathrm{F}_{4}$ & - & - & & 3.1 & 4.3 \\
\hline $\mathrm{F}_{5}$ & + & - & + & & 0.9 \\
\hline $\mathrm{F}_{6}$ & + & - & + & - & \\
\hline
\end{tabular}

3 時間值

\begin{tabular}{c|c|c|c|c|c}
\hline & 正常 & $\mathrm{F}_{1}$ & $\mathrm{~F}_{4}$ & $\mathrm{~F}_{5}$ & $\mathrm{~F}_{6}$ \\
\hline 正常 & & 1.3 & 2.2 & 4.2 & 11.1 \\
\hline $\mathrm{F}_{1}$ & - & & 0.7 & 2.3 & 8.6 \\
\hline $\mathrm{F}_{4}$ & - & - & & 1.3 & 7.2 \\
\hline $\mathrm{F}_{5}$ & + & - & - & & 7.3 \\
\hline $\mathrm{F}_{6}$ & + & + & + & + & \\
\hline
\end{tabular}

24時間值

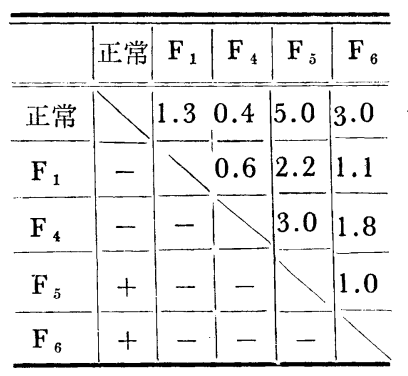

第35巻 第 9 号
6 時間值

\begin{tabular}{l|l|l|l|l|l}
\hline & 正常 & $F_{1}$ & $F_{4}$ & $F_{5}$ & $F_{6}$ \\
\hline 正常 & & 1.7 & 1.9 & 4.5 & 7.7 \\
\hline$F_{1}$ & - & & 0.1 & 2.7 & 6.0 \\
\hline$F_{4}$ & - & - & & 3.0 & 6.6 \\
\hline$F_{5}$ & + & - & - & & 6.2 \\
\hline$F_{6}$ & + & + & + & - & \\
\hline
\end{tabular}

$$
\begin{aligned}
& \mathrm{t}=\frac{\mathrm{M}_{1}-\mathrm{M}_{2}}{\sqrt{\mathrm{n}_{1} \mathrm{~S}_{1}{ }^{2}+\mathrm{n}_{2} \mathrm{~S}_{2}{ }^{2}}} \sqrt{\frac{\mathrm{n}_{1} \mathrm{n}_{2}\left(\mathrm{n}_{1}+\mathrm{n}_{2}-2\right)}{\mathrm{n}_{1}+\mathrm{n}_{2}}} \\
& \mathrm{M}_{1}, \mathrm{M}_{2} \cdots \text { 算術平均 } ; \mathrm{n}_{1} \mathrm{n}_{2} \cdots \text { 例数 } \\
& \mathrm{n}_{1} \mathrm{~S}_{1}{ }^{2}, \mathrm{n}_{2} \mathrm{~S}_{2}{ }^{2} \cdots \text { 偏差平方和 }
\end{aligned}
$$


間値 : $4.0 \pm 1.7 \% ， 12$ 時間值 : $5.2 \pm 2.2 \% ， 48$ 時間值 : $7.5 \pm 2.1 \%$ で最高值を示し, 次いで72時間値 $: 5.3 \pm$ $2.1 \%$ と減少している.

以上のように甲未 $\mathrm{F}$ ウサギの甲状腺 $\mathrm{I}^{13}{ }^{1}$ 摄取率はいずれ屯正常より高值を示し， $\mathrm{F}_{1}$ と $\mathrm{F}_{4}$ ウサギとの差違は あまりみとめられないが， $\mathrm{F}_{5}, \mathrm{~F}_{6}$ ウサギと代を重ねるに従つて 累代性に高い摂取率を示し, $\mathrm{F}_{6}$ ウサギの 3 時 間值は正常のそれの 2 倍以上の值を示している。 これら正常ならびに甲末 $F$ ウサギの $F_{1}$ および $F_{4} ， F_{5} ， F_{6}$ ウサギの相互間の $1,3,6,12,24$ 時間值について統計学的有意性を $\mathrm{t}=\frac{\mathrm{M}_{1}-\mathrm{M}_{2}}{\sqrt{\mathrm{n}_{1} \mathrm{~S}_{1}{ }^{2}+\mathrm{n}_{2} \mathrm{~S}_{2}{ }^{2}}} \sqrt{\frac{\mathrm{n}_{1} \mathrm{n}_{2}\left(\mathrm{n}_{1}+\mathrm{n}_{2}-2\right)}{\mathrm{n}_{1}+\mathrm{n}_{2}}}$ $\left(\mathrm{M}_{1}, \mathrm{M}_{2}\right.$ は算術平均值 $; \mathrm{n}_{1}, \mathrm{n}_{2}$ は例数； $\mathrm{n}_{1} \mathrm{~S}_{1}{ }^{2}, \mathrm{n}_{2} \mathrm{~S}_{2}{ }^{2}$ は偏差平方和）の式により，いずれむ $1 \%$ 有意水準 でしらべたところ。1 時間值では正常ウサギと $\mathrm{F}_{5}$ および $\mathrm{F}_{6}$ ウサギの間に有意の差がみとめられ，さらに $\mathrm{F}_{1}$, $\mathrm{F}_{4}, \mathrm{~F}_{5}$ ウサギと $\mathrm{F}_{6}$ ウサギの間にも有意の差がみとめられるが，正常と $\mathrm{F}_{1}$ および $\mathrm{F}_{4}$ 間， $\mathrm{F}_{1} \sim \mathrm{F}_{4}$ 間， $\mathrm{F}_{1}$ — $\mathrm{F}_{5}$ 間， $F_{4} \sim F_{5}$ 間には有意の差はなかつた。 3 時間值では正常〜 $F_{5}$ 間，正常〜 $F_{6}$ 間， $F_{1} \sim F_{6}$ 間， $F_{4} \sim F_{6}$ 間， $F_{5} \sim$ $F_{6}$ 間には有意の差はみられたが，正常〜 $F_{1}$ 間，正常〜 $F_{4}$ 間， $F_{1} \sim F_{4}$ 間， $F_{1} \sim F_{5}$ 間， $F_{4} \sim F_{5}$ 間には有意の差が みとめられない， 6 時間值では正常〜 $F_{5}$ 間，正常〜 $F_{6}$ 間， $F_{1} \sim F_{6}$ 間わよび $F_{4} \sim F_{6}$ 間には有意の差がみとめら れたが，その他の間には有意の差をみとめない. 12時間值においては正常と $F_{1}, F_{5}, F_{6}$ 間および $F_{4} \sim F_{5}$ 間。 $\mathrm{F}_{4} \sim \mathrm{F}_{6}$ 間には有意の差がみられたが，その他には有意の差がみられず，24時間值では正常〜 $F_{5}$ 間，正常〜 $F_{6}$ 間においてのみ有意の差をみとめた（第16表参照).

（4）甲摘子孫ウサギ $\left(F_{1}, F_{4}\right)$ の尹状腺 ${ }^{131}$ 摂取率測定成績（第17表，第 9 図参照）

(a) 甲摘 $\mathrm{F}_{1}$ ウサギ： 5 匹平均值は $\mathrm{NaI}^{131}$ 注射後 1 時間値: $31.8 \pm 4.7 \%$ で，次いで 3 時間值 $: 33.8 \pm$ $2.8 \%$ で最高值を示し，その後 6 時間值 : $32.0 \pm 5.2 \% ， 12$ 時間值 : $29.4 \pm 3.0 \% ， 24$ 時間值 $: 19.5 \pm 4.1 \%$ 之 次第に減少するが。いずれも正常平均值より高く，48時間值：7.8 $1.4 \% ， 72$ 時間值 : $4.8 \pm 1.5 \%$ では正常 より低値を示している。

(b) 甲摘 $\mathrm{F}_{4}$ ウサギ： 4 匹平均值は $\mathrm{NaI}^{131}$ 注射後 1 時間值 $: 24.9 \pm 3.7 \%$ $\mathrm{F}_{1}$ ウサギより低いが，その 後 3 時間值: $44.1 \pm 5.3 \%$ と高くなり。6 時間值 : $49.4 \pm 5.1 \%$ で最高值を示し, 次いで 12 時間値 : $31.1 \pm$ $10.3 \% ， 24$ 時間值 : $26.5 \pm 8.4 \% ， 48$ 時間值 : $20.0 \pm 6.3 \%$ 之次第に減少し，72時間值 : $16.6 \pm 5.5 \%$ いず

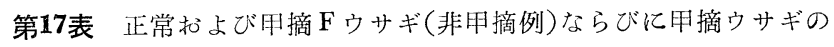

甲状腺 $\mathrm{I}^{131}$ 提取率测定成績 (\%)

\begin{tabular}{|c|c|c|c|c|c|c|c|c|c|c|}
\hline 種類 & $\begin{array}{l}\text { 動物 } \\
\text { 番号 }\end{array}$ & 性 & & 1 時 間 & 3 恃間 & 6 時 間 & 12 時 間 & 24 時 間 & 48 時間 & 72 時 間 \\
\hline 正常 & $\begin{array}{lll}+9 & 6 & \text { 例 } \\
\text { 今 } & 6 & \text { 例 }\end{array}$ & & & $\begin{array}{l}21.8 \pm 10.4 \\
(4.1 \sim 39.7)\end{array}$ & $\begin{array}{l}29.5 \pm 8.8 \\
(7.2 \sim 43.0)\end{array}$ & $\begin{array}{c}30.5 \pm 8.8 \\
(12.6 \sim 49.7)\end{array}$ & $\begin{array}{c}22.0 \pm 6.7 \\
(11.7 \sim 34.2)\end{array}$ & $\begin{array}{c}15.7 \pm 5.6 \\
(6.5 \sim 26.7)\end{array}$ & $\begin{array}{c}11.4 \pm 6.8 \\
(1.3 \sim 24.3)\end{array}$ & $\begin{array}{c}8.5 \pm 5.5 \\
(0.4 \sim 17.2)\end{array}$ \\
\hline \begin{tabular}{l|l} 
甲 & \\
摘 \\
李
\end{tabular} & $\begin{array}{l}21021 \\
21022 \\
21023 \\
21024 \\
21025\end{array}$ & $\left|\begin{array}{l}1 \\
0 \\
0 \\
0 \\
0 \\
0 \\
0 \\
\hat{1}\end{array}\right|$ & $\begin{array}{l}207 \\
162 \\
207 \\
162 \\
162 \\
\end{array}$ & $\begin{array}{l}36.5 \\
29.4 \\
37.1 \\
31.9 \\
24.3 \\
\end{array}$ & $\begin{array}{l}31.3 \\
32.5 \\
31.0 \\
37.3 \\
37.0 \\
\end{array}$ & \begin{tabular}{|l|}
29.2 \\
36.7 \\
27.1 \\
39.4 \\
37.4 \\
\end{tabular} & \begin{tabular}{|l|}
28.4 \\
26.4 \\
26.5 \\
32.8 \\
33.3 \\
\end{tabular} & $\begin{array}{l}18.2 \\
17.4 \\
14.0 \\
26.3 \\
21.5 \\
\end{array}$ & $\begin{array}{l}6.3 \\
9.0 \\
6.1 \\
8.0 \\
9.7 \\
\end{array}$ & $\begin{array}{l}7.3 \\
3.2 \\
4.8 \\
5.2 \\
3.5 \\
\end{array}$ \\
\hline $\begin{array}{l}\text { ウ } \\
\text { サ }\end{array}$ & 平均 & & & $31.8 \pm 4.7$ & $33.8 \pm 2.8$ & $32.0 \pm 5.2$ & $29.4 \pm 3.0$ & $19.5 \pm 4.1$ & $7.8 \pm 1.4$ & $4.8 \pm 1.5$ \\
\hline \begin{tabular}{l|l} 
热 & \\
摘 & \\
摘 & \\
\end{tabular} & $\begin{array}{l}24002 \\
24003 \\
24004 \\
24005 \\
\end{array}$ & $\mid$\begin{tabular}{l|}
0 \\
+ \\
0 \\
0 \\
+ \\
+
\end{tabular} & $\begin{array}{l}220 \\
220 \\
220 \\
220 \\
\end{array}$ & $\begin{array}{l}27.5 \\
20.5 \\
29.3 \\
22.1 \\
\end{array}$ & $\begin{array}{l}46.5 \\
38.2 \\
51.9 \\
39.9 \\
\end{array}$ & $\begin{array}{l}41.0 \\
54.6 \\
51.5 \\
50.3\end{array}$ & $\begin{array}{l}19.9 \\
21.7 \\
42.2 \\
40.6 \\
\end{array}$ & $\begin{array}{l}19.4 \\
17.2 \\
32.7 \\
36.8 \\
\end{array}$ & $\begin{array}{l}16.1 \\
11.8 \\
26.5 \\
25.7 \\
\end{array}$ & $\begin{array}{r}17.0 \\
8.5 \\
16.7 \\
24.0 \\
\end{array}$ \\
\hline$\underbrace{\text { 列 }}$ & 平均 & & & $24.9 \pm 3.7$ & $44.1 \pm 5.3$ & $49.4 \pm 5.1$ & $31.1 \pm 10.3$ & $26.5 \pm 8.4$ & $20.0 \pm 6.3$ & $16.6 \pm 5.5$ \\
\hline $\begin{array}{l}\text { 甲 } \\
\text { 摘 } \\
\text { 门 } \\
+\end{array}$ & $\begin{array}{r}3 \\
8 \\
16 \\
19 \\
\end{array}$ & 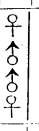 & $\begin{array}{l}215 \\
215\end{array}$ & $\begin{array}{l}2.4 \\
2.0 \\
2.1 \\
2.8 \\
\end{array}$ & $\begin{array}{l}5.0 \\
2.7 \\
2.4 \\
5.6 \\
\end{array}$ & $\begin{array}{l}8.0 \\
0.5 \\
3.3 \\
8.4 \\
\end{array}$ & $\begin{array}{l}1.9 \\
0.2 \\
3.4 \\
6.8 \\
\end{array}$ & $\begin{array}{l}1.7 \\
0.7 \\
2.7 \\
3.7 \\
\end{array}$ & $\begin{array}{l}0.5 \\
0.0 \\
3.1 \\
1.5 \\
\end{array}$ & $\begin{array}{l}0.7 \\
2.1 \\
0.6 \\
0.8 \\
\end{array}$ \\
\hline ギ & 平均 & & & $2.3 \pm 0.1$ & $3.9 \pm 1.4$ & $5.1 \pm 3.3$ & $3.1 \pm 2.4$ & $2.2 \pm 1.1$ & $1.3 \pm 1.2$ & $1.1 \pm 0.6$ \\
\hline
\end{tabular}


第 9 図正常扔上び甲摘 $\mathrm{F}$ ウサギ(非甲摘例)ならびに 甲摘ウサギの甲状腺 $\mathrm{I}^{131}{ }^{11}$ 掫取率測定成績 $(\%)$

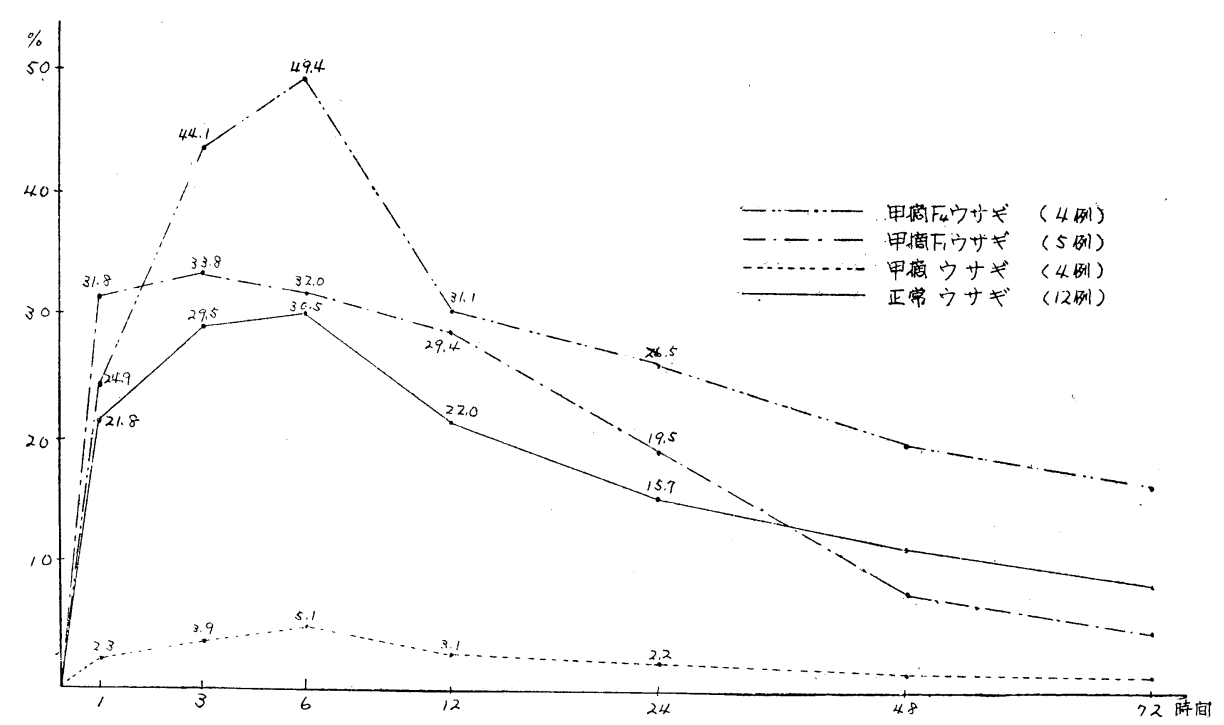

れも正常および $\mathrm{F}_{1}$ ウサギより高い椇取率を示している.

（5）甲摘ウサギの尹状腺 ${ }^{131}$ 摂取率測定成績（第17表，第 9 図参照）

4 匹平均值は $\mathrm{NaI}^{131}$ 注射後 1 時間值 : $2.3 \pm 0.1 \% ， 3$ 時間值 : $3.9 \pm 1.4 \% ， 6$ 時間值 $: 5.1 \pm 3.3 \%$ で最 高值を示し，その後 12 時間值 : $3.1 \pm 2.4 \% ， 24$ 時間值 : $2.2 \pm 1.1 \% ， 48$ 時間值 : $1.3 \pm 1.2 \%$ 之次第に減少し， 72時間值 : $1.1 \pm 0.6 \%$ で正常に比し非常に低い摄取率を示している.

\section{IV 考案}

今述べ実験成績についていささか考察を加えるとととする。

(1). 体重について

甲状腺機能立進症および Basedow 氏病においては新陳代謝の无進がみられ，従つて著明な体重の減少の あるととは一般に知られている。また実験的にあ甲状腺剤投与により著明な体重の減少をきたすとよはすで に立証されており ${ }^{107)}$ ，著者が親として用いた甲末投与ウサギにおいてあ同様の所見をみとめた。しかし Basedow 氏病の母体より生まれた胎児ならびに初生児については発育の促進があるとするもの ${ }^{93)}$ ，発育の遅 延があるとするあの $\left.{ }^{104}\right)$ などがあり，意見は一致しておらず，一方動物実験においてあ妊娠期間中に甲状腺 剂を投与して得られた胎仔および初生仔の発育についてあ同様に成績は一定していない2(107)108).

ひるがえつて動物の幼若期にその甲状腺を摘出する之成長発育が著明に障害されるが ${ }^{49 a}$ ) 49 b)，成熟したも のに甲摘を行うと代謝の低下のため体重が増加するととが観察されており ${ }^{67) 699}$ ，著者む親として使用した甲 摘ウサギに著明な体重の增加をみた。一方妊娠前あるいは妊娠期間中に甲状腺を摘出した母体より得られた 胎巟あるいは仔動物についてあ発育障害があるとするもの ${ }^{67) 699}$ ，およびぜんぜん体重の娍少はみられないと するあの ${ }^{86)}$ 等があり。一定の結果は得られていない，しかしこれらはいずれあ胎仔わよび初生仔についての 観察であり，妊娠前に甲状腺剂を投与し，あるいは甲摘を行つて得た子孫りサギについてその成長の経過を

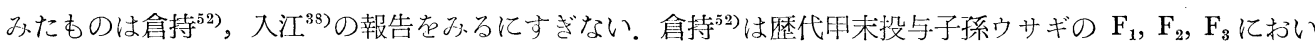
て正常に比しいずれす生後 120 日以後体重の增加が不良であつたと報告し，入江 ${ }^{38}$ は歴代甲摘子孫ウサギの $\mathrm{F}_{3}$ 亿おいてやや成長に障害があるととを観察している。著者の甲未投与子孫りサギにおいて $\mathrm{F}_{4} ， \mathrm{~F}_{5}$ および $\mathrm{F}_{6}$ ウサギは正常に比し僅かに成長が悪かつたが， $F_{1}$ ウサギでは正常よりむしろ体重の增加が良好であつた。 
また歴代甲摘子孫ウサギでは $\mathrm{F}_{1} ， \mathrm{~F}_{4}$ ウサギとも正常より成長がよく，特に $\mathrm{F}_{4}$ ウザ゙においては生後105日以 後著明な体重の増加がみられた。これはあるいは甲状腺機能低下状態と関係があるのではないかと考えられ るが，それを解明するにはなお詳細な観察が必要であるように思われる。

(2) 各検查成績について

ヒトの甲状腺機能立進症における血清 PBI の測定は第18表に示すように多くの報告が少られるが9, ウサ ギについてはその正常值の報告が $2 ， 3^{43368)}$ ある以外，甲状腺機能異常のさいの血清 PBI の測定に関する 報告は未だみられていない.

著者が行つた甲末 $\mathrm{F}$ ウキギにおける測定值は， $\mathrm{F}_{1}$ ウサギでは平均 $5.4 \pm 0.73 \gamma / \mathrm{dl}$ で， $\mathrm{F}_{4}$ ウサギでは平均 7.2 $\pm 1.80 \gamma / \mathrm{dl}$ ⿸示し， $\mathrm{F}_{5}$ ウサギでは $8.4 \pm 0.89 \gamma / \mathrm{dl}$ で， $\mathrm{F}_{6}$ ウサギでは平均 $10.0 \pm 1.07 \gamma / \mathrm{dl}$ で，いずれる正常平 均值 $4.6 \pm 0.71 \gamma / \mathrm{dl}$ より高く，功経代的に増加している，以上の血清 PBI 值につき統計学的にその有意性 をしらべたところ，正常と $F_{4}, F_{5}, F_{6}$ ウサギ間および $F_{1}$ と $F_{5} ， F_{6}$ 間， $F_{4} \sim F_{6}$ 間， $F_{5} \sim F_{6}$ 間に1\%の有意水 準で高度に有意の差がみとめられた。 なお各代とも雌，雄両性間の PBI 值の差は小さく，有意の差はみら れなかつた。

現在一般には健常者の血清 PBI は3.5 8.0 / d l をむつて正常範囲とされている ${ }^{77}$. この低い方の限界は あまり明膫ではなく，3r/d1以下ならばまず異常とみとめられている ${ }^{11)}$, 乙れに対し高い方の限界は明瞭で， $8 \mathrm{r} / \mathrm{dl}$ を越える場合は明らかに異常とみられている ${ }^{991)}$.

ヒトの甲状腺機能充進症については第18表に示すように多くの報告 ${ }^{9}$ がみられるが，Man ${ }^{57}$ は 15 人の患者に ついて測定を行い9.4〜33.7 $/$ dl に分布すると報告し，Riggs ら ${ }^{80)}$ は正常值の 2 ～倍を示すといつている.

第18表 健常者，甲状腺機能充進症扣上び甲状腺機能低下症に打ける P B I 值

(Blackburn \& Power $^{9}$ による)

\begin{tabular}{|c|c|c|c|c|c|c|c|c|c|}
\hline \multirow{3}{*}{ 著 } & 健 & 常 & 者 & \multicolumn{3}{|c|}{ 甲状腺機能宇進症 } & \multicolumn{3}{|c|}{ 甲状腺機能低下症 } \\
\hline & \multirow{2}{*}{ 例数 } & \multicolumn{2}{|c|}{ P B I $(r / d l)$} & \multirow{2}{*}{ 例数 } & \multicolumn{2}{|c|}{ P B I $(\gamma / \mathrm{dl})$} & \multirow{2}{*}{ 例数 } & \multicolumn{2}{|c|}{$\mathrm{P}$ B I $(r / \mathrm{dl})$} \\
\hline & & 平均值 & 分布範囲 & & 平均值 & 分布範囲 & & 平均值 & 分布範囲 \\
\hline Turner $ら$ & 40 & 6.3 & $3.6 \sim 10.4$ & 20 & 15.9 & $6.7 \sim 38.5$ & - & - & - \\
\hline Winkler $ら$ & - & - & - & 87 & 13.8 & $4.9 \sim 55.1$ & 25 & 1.3 & $0.2 \sim 2.5$ \\
\hline Kydd $ら$ & 83 & 5.3 & $3.8 \sim 8.6$ & 206 & - & $7.1 \sim 48.2$ & 93 & - & $0.0 \sim 3.0$ \\
\hline Starr 5 & 100 & 5.5 & $4.0 \sim 8.5$ & 208 & 12.3 & $3.5 \sim 25+$ & 39 & 2.1 & - \\
\hline $\begin{array}{c}\text { Snudermann } \& \\
\text { Sundermann }\end{array}$ & 65 & 5.0 & $2.9 \sim 7.9$ & 56 & - & $6.5 \sim 29.0$ & 15 & - & $0.4 \sim 3.4$ \\
\hline Blackburn \& Power & 530 & 5.2 & $2.5 \sim 8.3$ & 354 & 12.1 & $4.4 \sim 30.0$ & 113 & 1.3 & $0.0 \sim 5.2$ \\
\hline
\end{tabular}

第19表 各種実験動物の血清 P B I

正常値(Katsh \& Windsor ${ }^{43}$ による)

\begin{tabular}{lrr|r|r}
\hline \hline 種 & & 類 & 例数 & P B I $(\gamma / \mathrm{dl})$ \\
\hline ウ & マ & - & $3.6 \pm 0.4$ \\
サ & & ル & 3 & $6.0 \pm 0.7$ \\
ヒ & 9 & $シ$ & - & $3.7 \pm 0.3$ \\
ウ & サ & ギ & 4 & $3.3 \pm 0.5$ \\
ダイコクネズ & 15 & $4.5 \pm 0.4$ \\
モル モ & $ト$ & 5 & $2.5 \pm 0.5$ \\
ハムス タ & - & 5 & $3.5 \pm 0.4$ \\
カ ン ガ & 3 & $0.4 \pm 0.2$ \\
ニワトリのひな & 3 & $2.6 \pm 0.3$ \\
\hline
\end{tabular}

本邦においても平田 $\left.{ }^{33}\right)$ はいわゆる Merseburgの 3 主徴を備えた

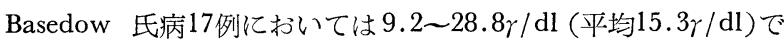
あるが，乙れを具備しない狭義の甲状腺機能元進症18例では7.1 〜 $19.0 \gamma / \mathrm{dl}$ (平均 $11.7 \gamma / \mathrm{dl}$ ) とやや低い範囲に分布することをみ とめている. Hallman $ら^{26)}$, Salter $ら^{84)}$, Winkler $ら^{106)}$ は本症の 94〜 100\%において血清 PBI が正常值以上であると報告し，ま た Starr ら ${ }^{91)}$ とれば甲状腺機能九進症の患者208人の血清 PBI 值は3.5〜25r/dlの範囲に分布し，平均12.3r/dlであるが，その 中 $7 \gamma / \mathrm{dl}$ 以上を示すすのは全体の97.5\%で，8 $\gamma / \mathrm{dl}$ 以上は94.5\% を占め, $9 \gamma / \mathrm{dl}$ 以上は真の病的状態 (actual disease state)である といつている. 
一方種々の実験動物の血清 PBI 正常值は第19表に示すように(Katsh ら $\left.{ }^{43}\right)$, ヒトに比輘して一般に低い値 を示している. ウサギの正常 PBI 值については Katsh ら ${ }^{43}$ の3 $3.3 \pm 0.5 \gamma / \mathrm{dl}\left(4\right.$ 匹) と西山 ${ }^{68}$ ) $3.3 \sim 6.0$ (5 匹）とがみられ，著者の測定した20 匹平均值 $4.6 \pm 0.71 \gamma / \mathrm{dl}$ むれらの報告とよく似た值を示している.

上記のようにヒトの正常:PBI 值に比してウサギのそれは約 $1 \gamma / \mathrm{dl}$ 程度低い. 従つてヒトの甲状腺機能充 進症の下限界は大体 $8 \gamma / \mathrm{dl}$ であるが, ウサギにおいては $7 \gamma / \mathrm{d}$ 以上で機能充進状態であると判定してよいの ではなかろうかと考元られる。著者の甲末 $\mathrm{F}$ ウサギでは $\mathrm{F}_{4}$ ウサギの半数， $\mathrm{F}_{5}$ の大部分， $\mathrm{F}_{6}$ の全例において $7 \mathrm{r} / \mathrm{d} 1$ 以上の值を示している.

次に血中総コレステロールについてみるに。甲末 $\mathrm{F}$ ウサギではその平均值はそれぞれ $\mathrm{F}_{1}:[95 \pm 6.8 \mathrm{mg} / \mathrm{dl}$ ， $\mathrm{F}_{4}: 84 \pm 8.0 \mathrm{mg} / \mathrm{dl}, \mathrm{F}_{5}: 97 \pm 15.5 \mathrm{mg} / \mathrm{dl}, \mathrm{F}_{6}: 98 \pm 14.7 \mathrm{mg} / \mathrm{dl}$ でいずれる 正常平均值 $82 \pm 14.9 \mathrm{mg} / \mathrm{dl}$ より僅か に高值を示した。

$M c \mathrm{Gee}^{60}$ は甲状腺機能九進症の㭧者の血清総コレステロール量は116 285 $\mathrm{mg} / \mathrm{dl}$ の範囲に分布し平均 162 $\mathrm{mg} / \mathrm{dl}$ であり，対照の正常人の150〜228mg/dl (平均 $193 \mathrm{mg} / \mathrm{dl}$ ) に比しやや低い場合があるが大部分は正常 範囲内であつたと報告し，Peters \& Man ${ }^{76)}$ は PBI と血清総コレステロールの值を比較し，PBI が正常值 $(8 \gamma / \mathrm{dl})$ 以上の時であ血清総コレステロールは大部分正常範囲内にあつたと報じており，Bartels $\left.{ }^{6}\right)^{6}$ 同 様に 甲状腺機能九進時には軽度の血清総コレステロールの変化をみるにすぎないから甲状腺機能九進症ではあま り診断的価值はないと述へている，著者の甲末 $\mathrm{F}$ ウザ゙れいてもその平均值はいずれも正常平均值よりや や高值であつたとはいうものの，個々の值は大部分正常範囲内 $59 \sim 110 \mathrm{mg} / \mathrm{dl}$ にあつた。

ウサギの甲状腺機能に関する放射性ヨードの使用実験は Hertz らの一連の研究29) 322)の他，2，3のあの がみられる ${ }^{1399}$. 倉持 ${ }^{593}$ は歷代甲状腺末投与子孫りサギ $\left(\mathrm{F}_{1} \sim \mathrm{F}_{3}\right)$ 亿おいて甲状腺 $\mathrm{I}^{131}$ 掑取率の增大をみとめた

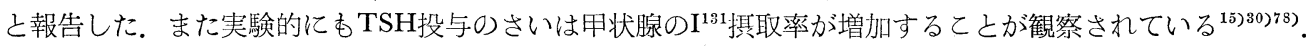
著者の実験では正常例にわいて 1 時間值 : $21.8 \% ， 3$ 時間值 : 29.5\%，6 時間值 : $30.5 \%$ で最高値を示し， 12時間值：22.0\%，24時間值：15.7\%，48時間值：11.4\%，72時間值：8.5\%であつたが。甲末 $\mathrm{F}$ ウサギで は経代的に摄取率が増大し， $\mathrm{F}_{6}$ ウサギにおいては 1 時間值 : $63.8 \% ， 3$ 時間值 : $64.5 \% ， 6$ 時間值 : $57.7 \%$, 12時間值：48.7\%，24時間值：27.5\%，48時間值：13.6\%，72時間值： $8.4 \%$ 之正常に比して高值を示し。 特に 1 時間值は正常の 3 倍， 3 時間值は約 2 倍， 6 時間個は1.9倍にも達している。乙れらの甲状腺 $\mathrm{I}^{131}$ 摄取 率につき統計学的にその有意性をしらべたところ，いずれも $1 \%$ 有意水準で 1 時間值では正常ウサギと $F_{5}$ および $\mathrm{F}_{6}$ ウサギの間ならびに $\mathrm{F}_{1}, \mathrm{~F}_{4}, \mathrm{~F}_{5}$ ウサギと $\mathrm{F}_{6}$ ウサギの間に高度に有意の差がみとめられ， 3 時間值 では正常〜 $F_{5}, F_{6}$ 間および $F_{6}$ 之各 $F$ 間に有意性がみられ，6 時間值では $F_{5}$ と正常および $F_{6}$ と正常， $F_{1} ， F_{4}$ 間に有意性がるとひられ，12時間值にわいては正常と $\mathrm{F}_{1}, \mathrm{~F}_{5}, \mathrm{~F}_{6}$ 間および $\mathrm{F}_{4}$ と $\mathrm{F}_{5} ， \mathrm{~F}_{6}$ 間において有意の差 がみられ，24洔間值では正常と $F_{5} ， F_{6}$ 間だけに有意の差をみとめた。すすなわち正常と $F_{5} ， F_{6}$ 間にはすべて の時間值において高度に有意の差がみとめられた。

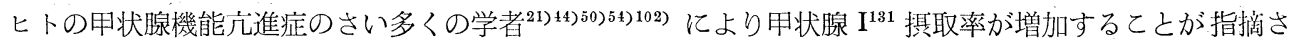

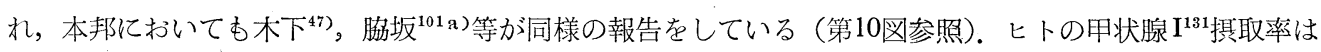
経口投与のさい12時間值で最高值を示し，以後わずか亿減少しながら120時間位まで同様の摂取率を持続す

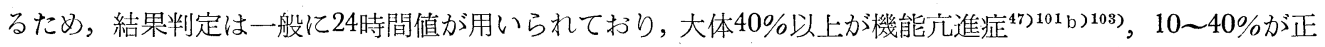

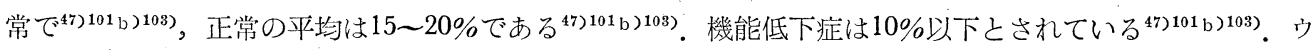
サギでは大体 3 ないし 6 時間值で最高值に達し以後ぜんじ減少するのは， $1^{131}$ の投与法が 静脈内注射である ことおよびヨードの代謝過程が七トに比し早急に行われるのであろうと推察される。ささ机経代的に高值を 示す甲末 $\mathrm{F}$ ウサギの摂取率曲線について考えてみるに，岩岡(10) が方進しているため甲状腺 $\mathrm{I}^{131}$ 曲線の上昇は速かで，最大值に達するまでの時間が短く，しかむその值は大 きい，こしてまた最大倠をとつた後下降を示すととがあるのは，甲状腺ホルモンの放出の克進を現わしてい るのであろうと述心゙ているのであつて，乙のととから案じて，著者の甲未 F ウサギでは妇状腺機能は経代的 に克進しているもの之考えられる。 


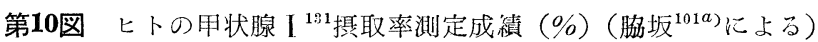

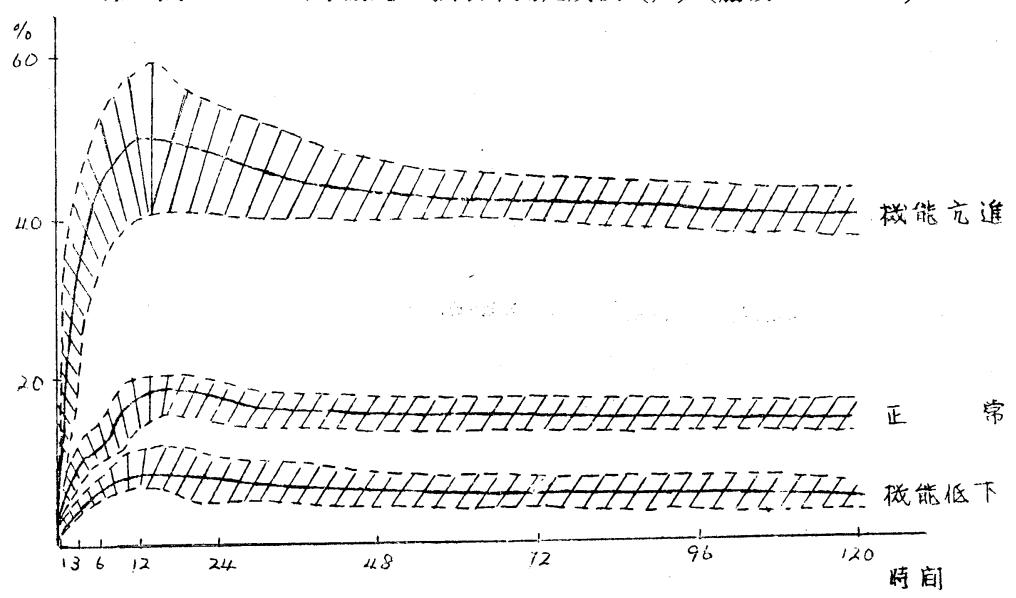

以上の各検查成績から甲末 $\mathrm{F}$ ゥサギにおいては経代的に増強する甲状腺機能九進状態を字し， $\mathrm{F}_{5}$ 以上のウ

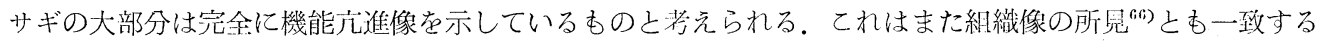
のである.

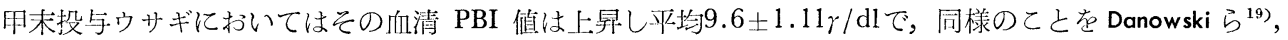
鳥飼 ${ }^{98)}$ ，Carr ら ${ }^{13)}$ はヒトおよびイヌについて報告しているが。この場合の血清 PBI の上景は thyroxine に よらないで，甲末に含まれている diiodotyrosine のためであり，従つてての值は必ずしあ甲状腺機能の程度 を示すむのとは限らないとされている(田中 ${ }^{95)}$, Carr ら ${ }^{13)}$ ).

甲末投与ウサギの血中総コレステロールは平均 $78 \pm 13.5 \mathrm{mg} / \mathrm{dl}$ で正常平均值 $82 \pm 14.9 \mathrm{mg} / \mathrm{dl}$ に比しわずか

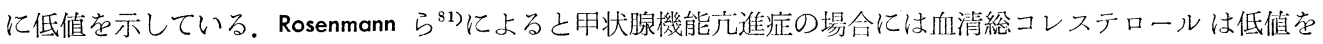
示すと報告し，その機序について肝においてコレスデールの合成は促進されるが，これと同跱に合成を越 えるコレステロールの分解が盛んに行われているためであると説明している.

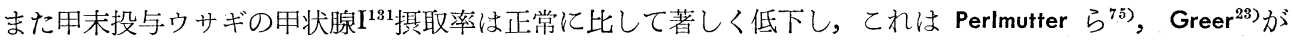
甲状腺剤を投与すると摂取率が減少しているという報告によく一致しており，乙の場合長期間の妇状腺剤投 与が脳下垂体に影響し，TSH の分泌を抑制するため椇取率の低下がみ.られるものと理解されている。

次に甲摘 $\mathrm{F}$ ウギにおける血清 $\mathrm{PBI}$ は， $\mathrm{F}_{1}$ ウサギでは平均 $4.2 \pm 0.61 \gamma / \mathrm{dl}$ で正常より僅汃低く， $\mathrm{F}_{4}$ ウ サギでは平均 $3.4 \pm 0.43 \gamma / \mathrm{dl}$ でさらに低值を示している。 ヒトの甲状腺機能低下症における血清 PBI の測定 は第18表に示すように多くの報告 ${ }^{9}$ があるが，Perkin ら ${ }^{73)}$ は2.5r/dl，Talbot ら ${ }^{94)}$ は $1.3 \sim 3.0 \gamma / \mathrm{dl}$ (平均2.3 $\gamma / \mathrm{dl})$ ，Salter ら ${ }^{83)}$ は2.2 $\gamma / \mathrm{dl}$ といずれあ低い平均值を示している。 また Starr ら ${ }^{91)}$ にれば甲状腺機能低下 症における39例の血清 PBI 值の平均は $2.1 \gamma / \mathrm{dl}$ で，最高値として $5.3 \gamma / \mathrm{dl}$ を示すむのをみとめたが，その中

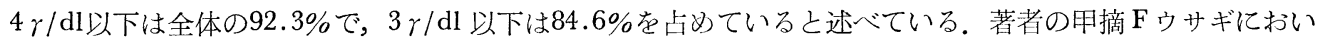
てはその血清 PBI 值は経代的に低值を示している.

甲摘 $\mathrm{F}$ ウサギの血中総コレステロールは $\mathrm{F}_{1}$ では平均 $95 \pm 13.3 \mathrm{mg} / \mathrm{dl}$ で正常平均值 $82 \pm 14.9 \mathrm{mg} / \mathrm{dl}$ より高 く， $\mathrm{F}_{4}$ では $123 \pm 44.2 \mathrm{mg} / \mathrm{dl}$ でさらに高值を示している。臨床的に甲状腺機能低下症では血清総コレステロ 一ルが増加している場合が多い. Mason $ら^{59}$ は22例の患者中15例が，Hurxthal ${ }^{36)}$ は33例中25例が増加していた と報じ，木邦においても鳥飼ら ${ }^{99}$ ，田中ら ${ }^{96}$ が同様の報告をしている．以上のように機能低下症では血清総 コレステロールの測定は有力な診断法の一つであるといえる。しかしての場合であ相当数において正常做を 示すことがあるのを考慮しなければならない.

甲摘 $\mathrm{F}$ ウサギの甲状腺 $\mathrm{I}^{131}$ 掑取率は， $\mathrm{F}_{1}$ では24時間值まで， $\mathrm{F}_{4}$ ではいずれの值む正常より高い摂取率を示 し， かつ $\mathrm{F}_{4}$ は $\mathrm{F}_{1}$ よりさらに高值を示した。 しかしてれらの血清 PBI は上記のようにいずれも正常より低 符 35 巻 第 9 号 
くかつ経代的に低值を示している. Chaikoff \& Taurog $^{15)}$ ，Morton ら ${ }^{65}$ はシロネズミに脳下垂体を剔出し，甲 状腺の機能低下を起させると，わずかながら摂取された $\mathrm{I}^{131}$ から di-iodotyrosine は容易に作られるが， thyroxine 形成が著しく阻害され，ホルモンとして血中に放出されるより以上のものが甲状腺内に蓄積され

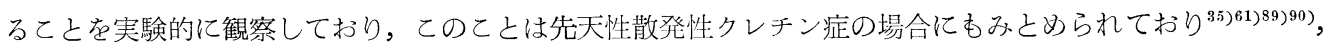
また thiocyanate 投与のさいにもみられている。こしててれらの例では $\mathrm{I}^{131}$ 摂取率はいずれも正常かまたは 正常より高值を示しており，また甲状腺内あるいは血中 thyroxine 量の減少がみられている.

以上のように著者の甲摘 $\mathrm{F}$ ウキギにおいては甲状腺 $\mathrm{I}^{131}$ 掑取率は正常より高く一見機能充進を疑わせたが， その血清 PBI は正常より低值で，血中総コレステロールも正常に比し増量していたことからこれらのウサ ギの甲状腺は主として無機ヨードの攝取能はあるが，これをホルモン化する合成能が障害されているのであ り，しかむこの障害は経代的に増強していくあののように考えられる。

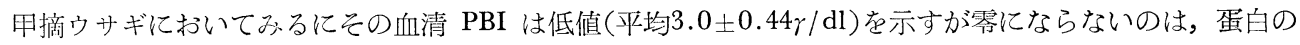
ヨード化(protein iodination)の現象あるいは甲状腺外(extrathyroidal) の有機ヨード合成の在在によるので はなかろうかと考えられている(Winkler $\left.ら^{105}\right)$. Carr $ら^{13}$ はイヌに甲摘を行い，その血清 PBI の低下を観 察しているが，ウサギにおけるこのような報告はみられない．次に甲摘ウサギの血中総コレステロールは平 均 $118 \pm 35.9 \mathrm{mg} / \mathrm{dl}$ で正常より高值を示し，Fleischmann ら ${ }^{22)}$ はウサギに，Chaikoff ら ${ }^{14)}$ はイヌに甲摘を行い

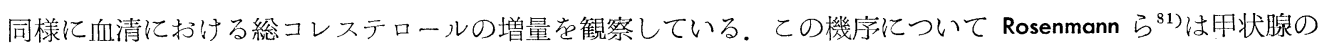
摘出動物ではコレステロールの吸収および体内においての生成が低下するが，同時にコレステロールの排浛 が著しく減少し，その結果血清中の総コレステロールが増加するといつている。また甲摘ウサギの甲状腺 $\mathrm{I}^{191}$

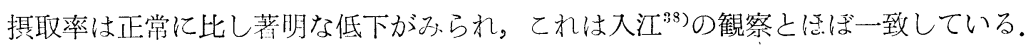

\section{$\mathrm{V}$ 結 論}

著者は歴代雌，雄甲状腺機能異常ウサギより生まれた子孫ウサギについてその甲状腺機能を研究し次の成 績を得た。

A 歴代甲状腺末投与雌，雄ウサギより生まれた子孫ウサギ $\left(\mathrm{F}_{1}, \mathrm{~F}_{4}, \mathrm{~F}_{5}, \mathrm{~F}_{6}\right)$ 亿おいて次の成績を得た.

(1) 体重の測定結果 $\mathrm{F}_{4}, \mathrm{~F}_{5}, \mathrm{~F}_{6}$ ウサギのいずれにおいてあ成長が正常とほとんど差がなかつた.

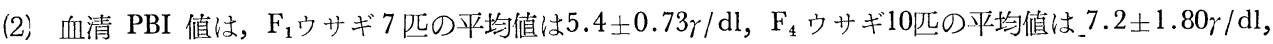
$\mathrm{F}_{5}$ ウサギ 8 匹の平均值は $8.4 \pm 0.89 \gamma / \mathrm{dl} ， \mathrm{~F}_{6}$ ウサギ 12 匹の平均值は $10.0 \pm 1.07 \gamma / \mathrm{dl}$ でいずれも正常平均值 4.6 $\pm 0.71 \gamma / \mathrm{dl}$ より高值を示し，かつ経代的に高くなり $\mathrm{F}_{6}$ ウサギでは正常の約 2.1 倍の值に達した.

（3）血中総コレステロール值は， $\mathrm{F}_{1}$ ウサギ 6 匹の平均值は $95 \pm 6.8 \mathrm{mg} / \mathrm{dl} ， \mathrm{~F}_{4}$ ウサギ 9 匹の平均值は $84 \pm$ $8.0 \mathrm{mg} / \mathrm{dl}, \mathrm{F}_{5}$ ウサギ 7 匹の平均值は $97 \pm 15.5 \mathrm{mg} / \mathrm{dl}, \mathrm{F}_{6}$ ウサギ10匹の平均㑤は $98 \pm 14.7 \mathrm{mg} / \mathrm{dl}$ でいずれあ 正常平均值 $82 \pm 14.9 \mathrm{mg} / \mathrm{dl}$ より僅汃に高い值を示した。

(4) 甲状腺 $\mathrm{I}^{131}$ 掑取率は， $\mathrm{F}_{1}, \mathrm{~F}_{4}, \mathrm{~F}_{5}, \mathrm{~F}_{6}$ ウサギとも正常より高值を示し，かつ経代的に増大し $\mathrm{F}_{6}$ ウサギで は 1 時間值は正常の約 3 倍， 3 時間值は約 2.2 倍，6 時間值は約1.9倍の椇取率を示した $\left(\mathrm{F}_{1} 5\right.$ 匹， $\mathrm{F}_{4} 6$ 匹， $\mathrm{F}_{5}$ 8 匹， $F_{6} 11$ 匹平均値は次の通りである.

1 時間佔 : $\mathrm{F}_{1} 34.1 \pm 5.1 \%,, \mathrm{~F}_{4} 33.6 \pm 8.9 \%, \mathrm{~F}_{5} 38.6 \pm 9.1 \%, \mathrm{~F}_{6} 63.8 \pm 4.4 \% ; 3$ 時間值 : $\mathrm{F}_{1} 35.9 \pm 7.9 \%, \mathrm{~F}_{4} 39.8$ $\pm 8.8 \%, \mathrm{~F}_{5} 45.7 \pm 6.3 \%, \mathrm{~F}_{6} 64.5 \pm 4.4 \% ; 6$ 時間值 $: \mathrm{F}_{1} 37.6 \pm 3.3 \%, \mathrm{~F}_{4} 37.8 \pm 1.7 \%, \mathrm{~F}_{5} 48.5 \pm 7.8 \%, \mathrm{~F}_{6} 57.7 \pm 6.6$ $\%$ \% 12時間值 : $\mathrm{F}_{1} 39.4 \pm 4.1 \%, \mathrm{~F}_{4} 32.1 \pm 6.3 \%, \mathrm{~F}_{5} 45.2 \pm 7.7 \%, \mathrm{~F}_{6} 48.7 \pm 7.4 \% ; 24$ 時間值 : $\mathrm{F}_{1} 20.7 \pm 5.1 \%, \mathrm{~F}_{4} 17.2$ $\pm 9.1 \%, \mathrm{~F}_{5} 32.4 \pm 8.6 \%, \mathrm{~F}_{6} 27.5 \pm 11.6 \% ; 48$ 時間值 $: \mathrm{F}_{1} 10.1 \pm 2.7 \%, \mathrm{~F}_{4} 8.2 \pm 5.1 \%, \mathrm{~F}_{5} 16.8 \pm 9.1 \%, \mathrm{~F}_{6} 13.6 \pm 4.8$ $\% ; 72$ 時間值 : $\left.\mathrm{F}_{1} 6.6 \pm 2.0 \%, \mathrm{~F}_{4} 6.4 \pm 4 \cdot 7 \%, \mathrm{~F}_{5} 13.3 \pm 9.0 \%, \mathrm{~F}_{6} 8.4 \pm 2.0 \%\right)$.

(5) 以上血清 PBI 值，甲状腺 $\mathrm{I}^{131}$ 掑取率汃ら歴代甲状腺末投与雌，雄ウサギより生まれた子孫ウサギにお いては累代性に増強する甲状腺機能九進状態を呈し，遂に $\mathrm{F}_{5}$ 以上のウサギの大部分は完全に機能六進像を 示しているあのと考えられる。

B 甲状腺末投与ウサギの 5 匹においては，血清 PBI 值 : $9.6 \pm 1.11 \gamma / \mathrm{dl}$ で正常より高く，血中総コレス 
テロール:78 $\pm 13.5 \mathrm{mg} / \mathrm{dl}$ で正常より僅かに低く, 甲状腺 $\mathrm{I}^{131}$ 摂取率は正常に比し著明な減少および遅趧を示した.

$\mathrm{G}$ 歴代甲状腺摘出雌, 雄ウサギより生まれた子孫ウサギ $\left(\mathrm{F}_{1}, \mathrm{~F}_{4}\right)$ 亿おいては次の成績を得た。

(1) 体重の測定結果 $F_{1} ， F_{4}$ ウサギとも正常より成長がやや良好で，特に $F_{4}$ において135日以後著明であつ t..

（2）血清 PBI 值は， $\mathrm{F}_{1}$ ウサギ 5 匹の平均值は $4.2 \pm 0.61 \gamma / \mathrm{dl} ， \mathrm{~F}_{4}$ ウサギ 6 匹の平均值は $3.4 \pm 0.43 \gamma / \mathrm{dl}$ で いずれも正常平均值 $(4.6 \pm 0.71 \gamma / \mathrm{dl})$ より低值を示し，かつ経代的に低くなつており，次第に甲摘ウサギの 平均值 $3.0 \pm 0.44 \gamma / \mathrm{dl}$ に近づいている.

（3）血中総コレステロールは， $\mathrm{F}_{1}$ ウキギ 5 匹の平均值は $95 \pm 13.3 \mathrm{mg} / \mathrm{dl}$ で， $\mathrm{F}_{4}$ ウサギ 5 匹の平均值は 123 $\pm 44.3 \mathrm{mg} / \mathrm{dl}$ でいずれあ正常平均值 $82 \pm 14.9 \mathrm{mg} / \mathrm{dl}$ より高く，かつ経代的に高值を示し， $\mathrm{F}_{4}$ では甲摘ウサギ の平均值 $118 \pm 35.9 \mathrm{mg} / \mathrm{d} 1$ 以上の值を示した.

(4) 甲状腺 $\mathrm{I}^{131}$ 摂取率は， $\mathrm{F}_{1} ， \mathrm{~F}_{4}$ ウサギとも正常より高い值を示し，かつ $\mathrm{F}_{4}$ は $\mathrm{F}_{1}$ よりさらに高值を示した $\left(\mathrm{F}_{1} 5\right.$ 匹, $\mathrm{F}_{4} 4$ 匹平均值は次の通りである。1 時間值: $\mathrm{F}_{1} 31.8 \pm 4.7 \%, \mathrm{~F}_{4} 24.9 \pm 3.7 \% ; 3$ 時間値: $\mathrm{F}_{1} 33.8 \pm$ $2.8 \%, \quad \mathrm{~F}_{4} 44.1 \pm 5.3 \% ; 6$ 時間值: $\mathrm{F}_{1} 32.0 \pm 5.2 \%, \quad \mathrm{~F}_{4} 49.4 \pm 5.1 \% ; 12$ 時間值 : $\mathrm{F}_{1} 29.4 \pm 3.0 \%, \quad \mathrm{~F}_{4} 31.1 \pm$ $10.3 \% ; 24$ 時間值 : $\mathrm{F}_{1} 19.5 \pm 4.1 \%, \mathrm{~F}_{4} 26.5 \pm 8.4 \% ; 48$ 時間值 : $\mathrm{F}_{1} 7.8 \pm 1.4 \%, \mathrm{~F}_{4} 20.0 \pm 6.3 \% ; 72$ 時間值： $\left.\mathrm{F}_{1} 4.8 \pm 1.5 \%, \mathrm{~F}_{4} 16.6 \pm 5.5 \%\right)$.

(5) 以上の結果より歴代甲状腺摘出雌，雄りサギより生まれた子孫りサギにおいては累代性に増強する主 として甲状腺のホルモン合成能障害による機能低下状態を示しているあのと考えられる.

$\mathrm{D}$ 甲状腺摘出ウサギの 5 匹においては，血清 $\mathrm{PBI}$ 值は $3.0 \pm 0.44 \gamma / \mathrm{d} l$ で正常より低く，血中総コレステ ロールは $118 \pm 35.9 \mathrm{mg} / \mathrm{dl}$ で正常に比し高值を示し，甲状腺 $\mathrm{I}^{131}$ 摂取率の 4 匹平均值では正常に比し著明な低 下を示した。

稿を終るに臨み，P B I 測定法の御教示を戴いた内科二講座の吉川守之学士に衷心より感謝する。

\section{文献}

1) Allen, L. : Studies on the fixation of radioactive iodine by the rabbit thyroid. Endocrinol., 32, 429432, 1943. 2) 浅田弘太郎 : 甲状腺過剩症, 胎児及ビ母体特二其ノ乳腺, 卵巣二及ボス影響二関スル実 験的研究. 日婦会誌，24，384 432，1928. 3) Barker, S.B. : Determination of protein-bound iodine. J. Biol. Chem., 24, 715-724, $1948 . \quad$ 4) Barker, S.B. \& Humphrey, M.J. : Clinical determination of protein-bound iodine in plasma. J. Clin. Fndocrinol., 10, 1136-1141, $1950 . \quad 5)$ Barker, S.B., Humphrey, M.J. \& Soley, M.J. : The clinical determination of protein-bound iodine. J. Clin. Invest., 30, 55-62, 1951. 6) Bartels, E.C. : Basal metabolic rate and plasma Cholesterol as aids in the Clinical study of thyroid disease. J. Clin. Endocrinol., 10, 1126-1135, 1950.

7) Baumann, E. : Über das normale Vorkommen von Jod in Tierkörper. Ztschr f. Physiol. Chem., 21, 319-330, $1895 . \quad$ 8) Bernheim, M., Berger, M. et Uzan, R. : La rôle des facteurs genétiques dans le développement du myxoedéme congénital. Compt. rend. Soc. Biol., 149, 1553-1558, $1955 . \quad$ 9) Blackburn, C.M. \& Power, M.H. : Diagnostic accuracy of serum protein-bound iodine determination in thyroid disease. J. Clin. Endocrinol., 15, 13791392, 1955. 10) Bloor, W.R. : The determination of cholesterol in blood. J.Biol. Ghem., 24, 227231, 1916. 11) Boas, N.F. \& Ober, W.B. : Hereditary exophthalmic goiter-report of eleven cases in one family. J. Clin. Endocrinol., 6, 575, 1946. (倉持 ${ }^{52)}$ による).

12) Brownel, G.L. and Stanbury, J.B. : Instrument for thyroid measurement. J. Glin. Endocrinol., 13, 210-220, 1953.

13) Carr, E.A., Beierwaltes, W.H., Raman, G., Dodson, V.N., Tanton, J., Betts, J.B. \& Stambaugh, R.A. : The effect of maternal thyroid function on fetal thyroid function and development. J. Clin. Endocrinol., 19, 1-18, 1959. 14) Chaikoff, I.L., Entenman, C., Changus, G.W. \& Reichert, F.L. : Influence of thyroidectomy on blood lipids of the dog. Endocrinol., 23, 797-805, 1941. 15) Chaikoff, I.L. \& Taurog, A. : Studies on the formation 
of organically bound iodine compounds in the thyroid gland and their appearance in plasma as shown by the use of radioactive iodine. Ann. N.Y. Acad. Sci., 50, 377-402, 1949.

16) Chaney, A.L. : Improvements in determination of iodine in blood. Indust \& Engin. Chem., Anal. Ed. 12, 179181, 1940.1 17) Connor, A.C., Swenson, R.E., Park, C.W., Gangloff, E.C., Lieberman, R. \& Curtis, G.M. : The determination of the blood iodine. A useful method for the clinical laboratory. Surgery, 25, 510517, $1949 . \quad 18)$ Danowski, T.S., Johnston, S.Y. \& Greenman, J.H. : Alteration in serum iodine fractions induced by the administration of inorganic iodide in massive dosage. J. Glin. Endocrinol., 10, 519531, 1950. 19) Danowski, T.S., Man, E.B. \& Winkler, A.W. : Tolerance of normal, of thyroidectomized, and of thiourea or thiouracil treated dogs to oral desiccated thyroid and to intravenous thyroxine. Endocrinol., 38, 230-237, $1946 . \quad 20)$ Epstein, A.A. \& Lande, H. : Studies on blood lipids ; relation of cholesterol and protein deficiency to basal metabolism. Arch. Int. Med., 30, 563-577, 1922.

Fields, T. \& Le Roy, G.V. : An accurate method for the measurement of radioiodine in the thyroid gland by an external counter. Radiology, 58, 57-67, 1952.

22) Fleischmann, W., Schmacker, H.B. \& Wilkins, L. : The effect of thyroidectomy on serum cholesterol and basal metabolic rate in the rabbit. Amer. J. Physiol., 131, 317-324, $1940 . \quad 23)$ Greer, M.A. : The effect of endogenous thyroid activity of feeding desiccated thyroid to normal human subjects. New Eng. J. Med., 244, 385-390, 1951. 24) Gross, J. \& Pitt-Rivers, R. : a) Physiological activity of $3: 5:$ 3'-L-triiodothyronine. Lancet, 1, 593-594, 1952. b) $3: 5:$ 3'-L-Triiodothyronine. Biochem. J., 53, 652-657, $1953 . \quad 25)$ Grossmann, A. \& Grossmann, G.F. : Protein-bound iodine by alkaline incineration and a method for producing a stable cerate color. J. Clin. Endocrinol., 15, 345-361, $1955 . \quad 26)$ Hallman, B.L., Bondy, P.K. \& Hageweed, M.A. : Determination of serum protein-bound iodine as a routine clinical procedure. Arch. Int. Med., 87, 817-824, 1951. 27) Hamilton, J.G. \& Soley, M.H. : a) Studies in iodine metabolism by the use of a new radioactive isotope of iodine. Amer. J. Physiol., 127, 557-572, 1939. b) Studies in iodine metabolism of the thyroid gland in situ by the use of radioiodine in normal subjects and in patients with various types of goiter. Ibid., 131, 135-143, 1940.

28) Harington, C.R. : Isoration of thyroxine from the thyroid gland. Biochem. J., 20, 293-299. 1926.

29) Hertz, S. : Radioactive iodine as an indicator in thyroid physiology. Observation on rabbits and on goiter patients. Amer. J. Roentgenol., 46, $467-468,1941$. 30) Hertz, S. \& Roberts, A. : Radioactive iodine as an indicator in thyroid physiology. III Iodine collection as a criterion of thyroid function in rabbits injected with thyrotropic hormone. Endocrinol., 29, 82-88, $1941 . \quad 31$ ) Hertz, S., Roberts, A. \& Evans, R.D. : Radioactive iodine as an indicator in study of thyroid physiology. Proc. Soc. Exper. Biol. \& Med., 38, 510-513, 1938. 32) Hertz, S., Roberts, A., Means, J.H. \& Evans, R.D. : Radioactive iodine as an indicator in thyroid physiology. Iodine collection by normal and hyperplastic thyroid in rabbits. Amer. J. Physiol., 128, 565-576, 1940. 33) 平田統一：健常者並びに各種内科疾患に打ける血清 P B I 亿関する研究. 日大医 誌, 15, 1190 1214, 1956. 34$)$ Hoskins, R.G. : Congenital thyroidism; An experimental study of the thyroid in relation to other organs of internal secretion. Amer. J. Physiol., 26, 426-438, 1910. 35) Hubble, D. : Familial cretinism. Lancet, 1, 1112-1117, 1953.

36) Hurxthal, L.M. : a) Blood cholesterol in thyroid disease. Arch. Int. Med., 52, 89-95, 1933. b) Blood cholesterol and thyroid disease; myxedema and hypercholestemia. Ibid., 53, 762-781, 1934.

37）今本広業：母体の甲状腺機能が産 仔に及ぼす影響についての实験的研究。逓信医学，8，1１9，1956.

38）入江一彦：歴代甲状腚摘出 雌，雄ウサギより生まれたウサギ $\left(\mathrm{F}_{1}\right.$ 〜 $\left.\mathrm{F}_{3}\right)$ 亿閣する研究。東北医誌，55，321～356，1957。 39) Irving, A., Bale, W.F., Vincent, D., Hodge, H.C., Walter, M., Stanbury, V.V., Warren, S.L. \& Wilson, H.J. : The distribution of radioactive isotopes of iodine in normal rabbits. Amer. J. Physiol., 122, 346-350, 1941. 
40）岩岡傾：甲状腺機能検查に抢ける放射性ヨードの応用。内分泌子代謝， 1，76〜82，1958. 金井泉：臨牀検查法提要，VII 42４3，金原出版株式会社，東京・京都，1955.

42）金地嘉夫，寺 田登美男，大久保忠，野崎英夫：甲状腺䛈贯の遗伝。日臨牀外科医誌，17回，5６号，31, 1956. Katsh, S. \& Windsor, E. : Unusual value for protein-bound iodine in the serum of the opossum. Science, 121, 897-898, 1955. 44) Keating, F.R., Wang, J.C., Luellen, T.J., Williams, M., Power, M.H. \& Conahey, W.M. : The measurement of the iodine-accumulating function of the human thyroid gland. J. Clin. Invest., 28, 217-227, $1949 . \quad$ 45) Kendall, E.C. : Tr. Ass. Amer. Physicians, 30, 428, 1915. (西山 ${ }^{68}$ に よる). 46) Kendall, E.C. \& Richardson, F.S. : Determination of iodine in blood and in animal tissues. J. Biol. Chem., 43, 161-170, 1920.

47) 木下文雄 : 放射性沃度 $I^{131}$ 亿よる甲状腺の臨床 的研究. I 放射性沃度による甲状腺疾患の診断的研究，慶応医学，22，379－388，1955. 48) Koerner， K.A. : Congenital goiter with exophthalmos and hyperthyroidism. J. Ped., 45, 464-470. 1954.4 49) 小山良修，左近さくら，細田明子，重井照子，藤井儔子：a）幼若ラットの発育とホルモン作用. 日薬理誌，

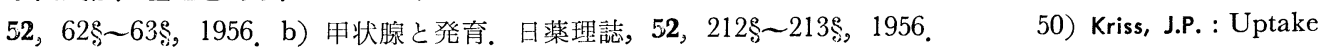
of radioactive iodine, $\mathrm{I}^{131}$, by the thyroid gland after administration of tracer doses. J. Clin. Endocrinol., 10, 812, 1950 . 51）久保政治，稲葉幸子，島田達雄，増田陽三，田所栄 : 精神薄弱児㳊関する 2.3 の検索。 3 .劣等児之甲状腺機能. 最新医学，7，732～736，1952. 52 ) 倉持利男: 歴代甲状腺末 投与雌，雄ウサギより生まれた子孫ウサギ $\left(\mathrm{F}_{1} \sim \mathrm{F}_{3}\right)$ 亿関する研究. 東北医誌，55，357～381，1957. 53) Lewis, I.C. \& Mac Gregor, A.G. : Congenital hyperthyroidism. Lancet, 5, 14 16, $1957 . \quad 54)$ Luellen, T.J., Keating, F.R., Williams, M., Berkson, J., Power, M.H. \& Mc Conahey, W.M. : Relative measurement in vivo of accumulation of radioiodine by the human thyroid gland; Comparison with radioactivity of peripheral tissues. J. Clin. Invest., 23, 207-216, $1949 . \quad$ 55) Mackenzie : Lancet, September, 1890. (White ${ }^{104}$ による). $\quad$ 56) Man, E.B., Culotta, C. B., Siegfried, D.A. \& Stilson, C. : Serum precipitable iodines in recognition of cretinism and in control of thyroid medication. J. Ped., 31, 154-160, 1947. 57) Man, E.B., Smirnow, A.E., Gildea, E.F. \& Peters, J.P. : Serum iodine fractions in hyperthyroidism. J. Clin. Invest., 21, 773-780, $1942 . \quad$ 58) Martin, J.M. : Proc. Roy. Soc. Med., 32, 215, 1939.(倉持 ${ }^{52}$ そよる). 59) Mason, R.L. et al. : New Eng. J. Med. 233, 1273, 1930. (田中弓 ${ }^{96)}$ にる). 60) Mc Gee, L.C. : Ann. Int. Med., 9, 728, 1935. (田中ら ${ }^{96}$ 亿よる). 61) Mc Girr,E.M. \& Hutchison, J.H. : Radioactiveiodine studies in non-endemic goitrous cretinism. Lancet, 1, 1117-1120, 1953.62$)$ Means, J.H., Lerman, J. \& Salter, W.T. : J. Clin. Invest., 19, 683, 1940. (西山 ${ }^{68}$ そょる). 63) Member, S., Bruger. M. \& Oppenheim. E. : Experimental atherosclerosis. Arch. Path., 38, 210-214, $1944 . \quad 64)$ Morrison : New Eng. J. Med., 199, 85, 1928. (倉持 ${ }^{52}$ ) 飞よる). 65) Morton, M.E., Perlman, I., Anderson, E. \& Chaikoff, I.L. : Radioactive iodine as an inticator of the metabolism of iodine. Endocrinol., 30, 495-501，1942. 66）中島養鄉：未発表. 67) 中村字一：妊娠，分娩並ビ二産槈時甲状腺機能二 関スル実験的研究.（其の2）甲状腺剔出ノ妊娠持続並ビ二胎児発育二及ボス影響. 近畿婦誌，16，1050 1057，1932. 68) 西山恒雄 : 産婦人科領域二於ヶル血清蛋白結合沃度 (P B I )二就テノ研究. 日産婦 誌，9，215 224，1957. 69）野島規矩男: 甲状腺剔出ノ妊娠二及ボス影響二就テノ実験的研究. 近 畿婦誌，16，846～902，1932. 70）岡本棒造：a）糖尿病ノ実験的研究. 日病会誌，41(総会号). 2743, 1952. b) Experimental pathology of diabetes mellitus (ReportII.). III. Studies on rabbits from ancestors diabetic for several successive generations, especially on spontaneous occurrence of diabetes in $\mathrm{F}_{4}$ and $\mathrm{F}_{5}$ rabbits. Tohoku J. Exper. Med., 61, Suppl. III, 62-112, 1955. c) 実験的糖尿病八子孫二及 ボス影響. 日内分泌誌，24，824〜845，1958. 71) 大西康夫 : 鷄胎児発育二及ボス諸内分泌ノ影響.

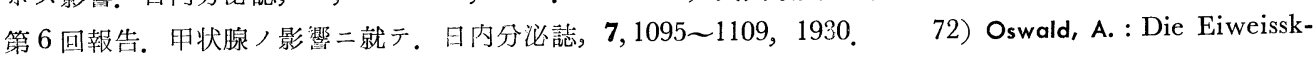
örper der Schilddrüse. Ztschr, f. Physiol. Chem., 27, 14-49, 1899. 73) Perkin, H.J. \& Hurxthal, L.M. : 
1002

正常ならびに歴代雌，雄甲状腺機能異常ウサギより生まれた子孫ウサギ

$\left(\mathrm{F}_{1}, \mathrm{~F}_{4}, \mathrm{~F}_{5}, \mathrm{~F}_{6}\right)$ の甲状腺機能について (山崎)

The fractionation of the iodine of blood in thyroid disease. J. Clin. Invest., 18, 733-737, 1939.

Perlmutter, M. \& Riggs, D.S. : Thyroid collection of radioactive iodide and serum protein-bound iodine concentration in senescence, in hypothyroidism and in hypopituitarism. J. Clin. Endocrinol., 9, 430439, 1949. 75) Perlmutter, M., Weisenfeld, S., Salter, S. \& Wallace, E.Z. : A study of the metabolism of the inhibition of the thyroid gland induced by ingestion of thyroid substance. J. Clin. Endocrinol., 12, 208-227, $1952 . \quad$ 76) Peters, J.P. \& Man, E.B. : Nhe significance of serum cholesterol in thyroid disease. J. Clin. Invest., 29, 1-11, 1950.

77) Rapport, R.L. \& Curtis, G.M. : The clinical significance of the blood iodine : A review. J. Clin. Endocrinol., 10, 735-790, 1950.

78) Rawson, R.W. \& Skanse, B.N. : Radioactive iodine : Its use as a tool in studying thyroid physiology. Radiology, 51, 525-531, $1948 . \quad$ 79) Reid, A.F. \& Sorenson, J.A.: Effective thyroid depth and compensating measurements for iodine uptake determination. Radiology, 58, 390-392, $1952 . \quad$ 80) Riggs, D.S., Gildea, E.F. \& Man, E.B. : The clinical interpretation of blood iodine levels. Connecticut M.J., 5, 209, 1941. (Rapport $5^{77}$ )による). $\quad$ 81) Rosenmann, R.H., Byer, S.O. \& Friedman, M. : The mechanism responsible for the altered blood Cholesterol content in deranged thyroid states. J. Clin. Endocrinol., 12, 1287-1299, $1952 . \quad$ 82) Sandall, E.B. \& Kalthoff, I.M. : Micro determination of iodine by a catalytic method. Mikrochimica acta, 1, 9-25, $1937 . \quad$ 83) Salter, W.T., Bassett, A.M. \& Sappington, T.S. : Protein-bound iodine in blood. IV. It's relation to thyroid function in 100 cases. Am. J.M. Sci., 202, 527-542, $1941 . \quad$ 84) Salter, W.T. \& Mc Kay, E.A. : Iodine in blood and thyroid of man and small animals. Endocrinol., 35, 380-390, $1944 . \quad 85)$ 佐々木哲丸，中島博徳，森和夫：血族性に見られた甲 状腺腫. 内分泌，2，70，1955. 86) Schulze，W., Schmitt, W. und Hölldobler, K. : Untersuchungen über die morphogenetische Wirksamkeit der embryonalen Schilddrüse der Säugetiere, besonders des Menschen. Endokrinologie, 2, 2-19，1928. 87）七条小次郎，田中茂：血清蛋白結合沃度及その測定法につ いて. ホルモンと臨牃，1，153〜161, 1953. 88) Skelton, M.O. \& Gans, B. : Congenital thyrotoxicosis. Arch. Dis. Childh., 30, 460-464, 1955. report. J. Glin. Endocrinol., 11, 740-742, 1951. 89) Stanbury, J.B.: Cretinism with goiter : A case family of goitrous cretins. J. Glin. Endocrinol., 10, 1471-1484, $1950 . \quad$ 91) Starr, P., Petit, D.W., Chaney, A.L., Rollman, H., Aiken, J.B., Jamieson, B. \& Kling, I. : Clinical experience with the blood proteinbound iodine determination as a routine procedure. J. Clin. Endocrinol., 10, 1237-1250, 1950.92 92) Sugiyama, S. \& Yagizawa, T. : On the postnatal histogenesis of the thyroid gland of the rabbit. 3. On the thyroid function researched from the histogenetic point of view. Fol. Anat. Jap., 23, 67-79, 1950. 93) 高橋敏行：母体二於ヶル甲状腺機能障碍ガ其ノ胎児又八乳児ノ内分泌臟器二及ボス影響二就テ. 日内分 泌誌，5，923９87，1928. 94) Talbot, N.B., Butler, A.M., Saltzman, A.H. \& Rodriguez, P.M.: The colorimetric estimation of protein-bound serum iodine. J. Biol. Chem., 153, 479-488, 1944.95$)$ 田中茂 : 甲状腺機能の化学的検查法. ホルモンと臨牀，4，966９72，1956. 96 ) 田中茂, 中野稔: 最 も新しいホルモン検查法. 協同医書出版社, 東京, 164，1956. 97 97) Taurog, A. \& Chaikoff, I.L. : On the determination of plasma iodine. J. Biol. Chem., 163, 313-322, 1946. 98) 鳥趼龍生 : 甲状腺の 臨床. II.甲状腺機能低下症の診断々治療. 日内科学誌，46，1247～1261，1958. 99) 鳥絽龍生，白 井堅雄：甲状腺疾患の彰断。綜合臨牀，5，972～980. 1956. 100）辻田純一：未発表. 101) 脇坂行一：a）甲状腺の臨床. 目。放射性同位元素による甲状腺機能検查を中心として. 日内科学誌，46， 1262 1295，1958，b) 放射性同位元素の医学的応用. 内科宝函，3，279～289，1956. 102) Werner， S.C., Hamilton, H.B., Leifer, D. \& Goodwin, L.D. : An appraisal of the radioiodine tracer technic as a clinical procedure in the diagnosis of thyroid disorders J. Clin. Endocrinol., 10, 1054-1076, 1950. 103) Werner, S.C., Quimby, E.H. \& Schmidt, C. : The use of tracer doses of radioactive iodine, $\mathrm{I}^{131}$, in the 
study of normal and disordered thyroid function in man. J. Clin. Endocrinol., 9, 342-354, 1949. 104) White, C. : A foetus with congenital hereditary Graves's disease. J. Obst. \& Gynaec., Brit. Emp., 21, 231-233, $1912 . \quad$ 105) Winkler, A.W., Riggs, D.S. \& Man, E.B. : Serum iodine in hypothyroidism before and during thyroid therapy. J. Glin. Invest., 24, 732-741, $1945 . \quad$ 106) Winkler, A.W., Riggs, D.S., Thompson, K.W. \& Man, E.B. : Serum iodine in hyperthyroidism, with particular reference to the effects of subtotal thyroidectomy. J. Clin. Invest., 25, 404-487, $1937 . \quad 107)$ 安間善雄: 甲状腺厂木 ルモン」ノ家兔胎仔発育二及ボス影響二就イテ．解剖誌，12，426４87，1937。 108) 陽田伝 : 卵巣

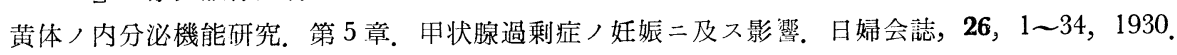

